Carla Bianca Bittar

\title{
EDUCAÇÃO E DIREITOS HUMANOS: UMA ANÁLISE DOS RELATÓRIOS DA PLATAFORMA DhESCA SOBRE A EDUCAÇÃO NO BRASIL DE 2003 A 2009
}

\author{
Dissertação de Mestrado \\ Orientadora: Profa. Dra. Flávia Inês Schilling
}

Faculdade de Direito da Universidade de São Paulo

São Paulo 


\title{
Carla Bianca Bittar
}

\section{EDUCAÇÃO E DIREITOS HUMANOS: UMA ANÁLISE DOS RELATÓRIOS DA PLATAFORMA DhESCA SOBRE A EDUCAÇÃO NO BRASIL DE 2003 A 2009}

\begin{abstract}
Dissertação apresentada à Banca Examinadora da Faculdade de Direito da Universidade de São Paulo, como exigência parcial para obtenção do título de Mestre em Direitos Humanos, sob a orientação da Professora Doutora Flávia Inês Schilling.
\end{abstract}

\section{São Paulo}


Nome: BITTAR, Carla Bianca

Título: Educação e direitos humanos: uma análise dos relatórios da Plataforma DhESCA sobre a educação no Brasil de 2003 a 2009

Dissertação apresentada à Banca Examinadora da Faculdade de Direito da Universidade de São Paulo, como exigência parcial para obtenção do título de Mestre em Direitos Humanos, sob a orientação da Professora Doutora Flávia Inês Schilling.

Aprovado em:

Banca Examinadora

Prof. Dr. Instituição:

Julgamento: Assinatura:

Prof. Dr. Instituição

Julgamento: Assinatura:

Prof. Dr. Instituição: Assinatura: 
Ao Vagner 


\section{AGRADECIMENTOS}

A todos aqueles que, direta ou indiretamente contribuíram para que este sonho fosse possível.

Especialmente, à Profa. Dra. Flávia Inês Schilling pela cuidadosa e empenhada missão de guiar e acompanhar os meus passos no decorrer desta jornada.

Ao meu esposo Vagner, por todo o amor, apoio, suporte e companheirismo em todos os momentos.

À memória de meu pai, sempre presente pelas lições de vida e estímulo ao estudo e pesquisa acadêmicos.

À minha querida mãe Rosa Wanda, fonte inesgotável de amor e carinho, pelo apoio, auxílio e compreensão durante todo o tempo.

Ao Eduardo Carlos, com quem tive o privilégio de contar com o apoio e incentivo de irmão, além de dividir os diálogos dentro e fora do ambiente acadêmico.

À Aurélia, Fernando e Fátima, pela torcida para a realização desta conquista.

A todos os amigos que acompanharam e estiveram por perto durante todo o percurso do mestrado.

A todos aqueles que acreditam e que, de alguma forma, se empenham para que a educação e o respeito aos direitos humanos seja sempre o principal caminho para a libertação. 


\section{RESUMO}

BITTAR, Carla Bianca. Educação e direitos humanos: uma análise dos relatórios da Plataforma DhESCA sobre a educação no Brasil de 2003 a 2009. 2012. 157 f. Dissertação (Mestrado) - Faculdade de Direito, Universidade de São Paulo, São Paulo, 2012.

A presente pesquisa possui como objetivo detectar avanços e impasses da educação no País, analisando os principais problemas surgidos na concretização deste direito. Para tanto, busca refletir sobre a efetivação da educação como um direito humano, adotando como ponto de partida o contexto dos direitos humanos em que se encontra inserida, com suas características de indivisibilidade, universalidade e interdependência na garantia da dignidade da pessoa humana. Para a promoção desta reflexão, a metodologia adotada fora a revisão bibliográfica e análise dos relatórios brasileiros sobre educação produzidos pela Plataforma Brasileira de Direitos Humanos Econômicos, Sociais, Culturais e Ambientais (DhESCA) no período de 2003 a 2009. A primeira parte apresenta um apanhado geral sobre as barreiras que impedem a efetivação do direito à educação até os dias atuais, tanto do ponto de vista histórico quanto do ponto de vista jurídico. A segunda parte contextualiza a relação entre educação e direitos humanos, ressaltando-se que por meio do reconhecimento do direito à educação resgatam-se também outros valores, tais como a igualdade, a cidadania e o acesso a outros direitos. A terceira parte traz um apanhado geral do arcabouço legislativo nacional e internacional onde a educação está inscrita, analisandose a sua concepção e tratamento a partir destes. Destaca-se, também a importância do papel desempenhado pelas organizações não governamentais para a plena efetivação do direito à educação. A parte final faz a análise propriamente dita da educação nos referidos relatórios nacionais, demonstrando-se os fracassos dos governos ao não promover a igualdade material deste direito em conjunto com os demais direitos humanos. Por derradeiro, as considerações finais relacionam as constatações feitas ao longo da pesquisa, retomando as discussões apresentadas na parte inaugural.

Palavras-chave: Educação. Direitos humanos. Relatórios brasileiros. Plataforma Brasileira de Direitos Humanos Econômicos, Sociais, Culturais e Ambientais. 


\begin{abstract}
BITTAR, Carla Bianca. Education and human rights: an analysis of the Platform DhESCA reports on education in Brazil from 2003 to 2009. 2012. 157 f. Dissertação (Mestrado) - Faculdade de Direito, Universidade de São Paulo, São Paulo, 2012.

This research has the objective of detecting which way education is being conducted in the country, analyzing the main problems encountered in implementing this law. Therefore, it seeks to reflect on the effectiveness of education as a human right, taking as its starting point the human rights context in which is inserted, keeping therefore the same characteristics: the indivisibility, universality and interdependence in guarantee of human dignity. To promote this reflection, the methodology was a literature review and analysis of reports on education produced by Brazilian Platform of Human Rights Economic, Social, Cultural and Environmental Rights (DhESCA) in the period 2003 to 2009. The first part presents an overview about the barriers that prevent the realization of the right to education until the present day, both from the standpoint of historical and legal point of view. The second part contextualizes the relationship between education and human rights, emphasizing that by recognizing the right to education is also rescue other values such as equality, citizenship and access to other rights. The third part presents an overview of national and international legislative framework in which education is entered, analyzing its design and treatment from them. Another highlight is the importance of the role played by non-governmental organizations for the full realization of the right to education. The final part is the actual examination of education in these national reports, demonstrating the failures of governments failing to promote equality of the right material together with other human rights. For the last, the final considerations relate the findings made during the research, resuming the discussions presented at the inaugural.
\end{abstract}

Keywords: Education. Human rights. Reports brazilian. Education at the concrete level. Brazilian Platform of Human Rights Economic, Social, Cultural and Environmental. 


\section{LISTA DE SIGLAS}

Abrandh Associação Brasileira de Nutrição e Direitos Humanos

Agende Ações em Gênero, Cidadania e Desenvolvimento

AMB Articulação de Mulheres Brasileiras

AMNB Articulação de Organizações de Mulheres Negras Brasileiras

Apae Associação de Pais e Amigos dos Excepcionais

CDVHS Centro de Defesa da Vida Herbert de Souza

Ceap Centro de Educação e Assessoramento Popular

Cedaw Convenção sobre Eliminação de Todas as Formas de Discriminação contra a Mulher

Cels Centro de Estudos Legais e Sociais

Cendhec Centro Dom Helder Câmara de Estudos e Ação Social

CF Constituição Federal

Cfemea Centro Feminista de Estudos e Assessoria

CICV Comitê Internacional da Cruz Vermelha

Ciep Centro Integrado de Educação Pública

Cimi Centro Indigenista Missionário

CJP-SP Comissão de Justiça e Paz de São Paulo

Conic Conselho Nacional de Igrejas Cristãs

CPT Comissão Pastoral da Terra

Desc Comissão de Direitos Econômicos, Sociais e Culturais

DhESC Direitos Humanos Econômicos, Sociais e Culturais

DhESCA Plataforma Brasileira de Direitos Humanos Econômicos, Sociais, Culturais e Ambientais

EC Emenda Constitucional

Enem Exame Nacional do Ensino Médio

FAO Organização das Nações Unidas para Agricultura e Alimentação

Fase $\quad$ Federação dos Órgãos de Assistência Social e Educacional

Fian Brasil Rede de Informação e Ação pelo Direito Humano a se Alimentar

Funap $\quad$ Fundação Prof. Dr. Manoel Pedro Pimentel de Amparo ao Preso 
Fundeb Fundo de Manutenção e Desenvolvimento da Educação Básica e de Valorização dos Profissionais da Educação

Fundef Fundo de Manutenção e Desenvolvimento do Ensino Fundamental e de Valorização do Magistério

Gajop Gabinete de Assessoria Jurídica às Organizações Populares

Ibase Instituto Brasileiro de Análises Sociais e Econômicas

IBGE Instituto Brasileiro de Geografia e Estatística

IDC Incidente de deslocamento de competência

Inee Inter-Agency Network for Education in Emergencies

Inep Instituto Nacional de Estudos e Pesquisas Educacionais

Inesc Instituto de Estudos Socioeconômicos

Infopen Sistema Integrado de Informações Penitenciárias

LBTTTI Pessoas Lésbicas, Bissexuais, Travestis, Transgênero, Transexuais e Intersexual

LDB Lei de Diretrizes e Bases da Educação Nacional

LEP Lei de Execuções Penais

MAB Movimento Atingidos por Barragens

MEB Movimento de Educação de Base

MEC Ministério da Educação

MMC Movimento das Mulheres Camponesas

MNDH Movimento Nacional de Direitos Humanos

MNMMR Movimento Nacional de Meninos e Meninas Rua

MPF Ministério Público Federal

MST Movimento dos Trabalhadores Rurais Sem Terra

NOA Região Noroeste da Argentina

NU Nações Unidas

OAB Ordem dos Advogados do Brasil

OC Opinião consultiva

OEA Organização dos Estados Americanos

OIT Organização Internacional do Trabalho

ONG Organização não governamental

ONU Organização das Nações Unidas

PAC Programa de Aceleração do Crescimento

PCC Primeiro Comando da Capital 
PIDHDD Plataforma Interamericana de Direitos Humanos, Democracia e Desenvolvimento

Pidesc Pacto Internacional dos Direitos Econômicos, Sociais e Culturais

Pnad Pesquisa Nacional de Amostra por Domicílio

PNDH Programa Nacional de Direitos Humanos

PNE Plano Nacional de Educação

Pnud Programa das Nações Unidas para o Desenvolvimento

Pronasci Programa Nacional de Segurança Pública com Cidadania

ProUni Programa Universidade para Todos

PEC Proposta de Emenda à Constituição

Rede Saúde Rede Feminista de Saúde, Direitos Sexuais e Reprodutivos

Rede Social Rede Social de Justiça e Direitos Humanos

SDDH Sociedade Paraense de Defesa dos Direitos Humanos

SMDH Sociedade Maranhense de Direitos Humanos

Susipe Superintendência do Sistema Penitenciário do Estado do Pará

STF Supremo Tribunal Federal

STJ Superior Tribunal de Justiça

Unesco Organização das Nações Unidas para a Educação, a Ciência e a Cultura

Unicef Fundo das Nações Unidas para a Infância

UNV United Nations Volunteers

VNU Programa dos Voluntários das Nações Unidas 


\section{SUMÁRIO}

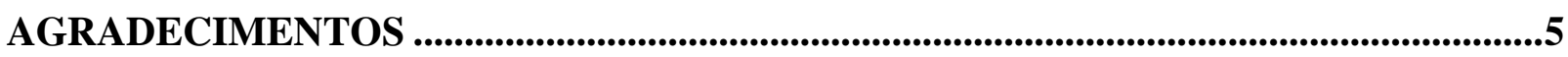

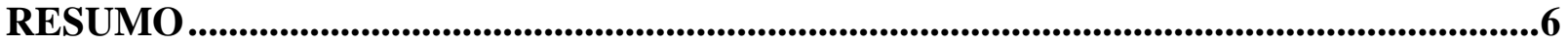

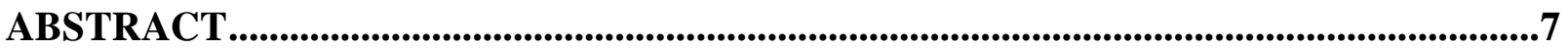

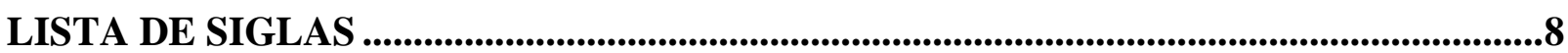

INTRODUÇÃ

1 CARACTERIZAÇÃo GERAL DA EDUCAÇÃo COMO DIREITO HUMANO: CONSIDERAÇÕES PRELIMINARES ....................................................25

1.1 Os direitos sociais na concepção de direitos fundamentais........................................................25

1.2 A problemática da efetividade dos direitos sociais .....................................................................27

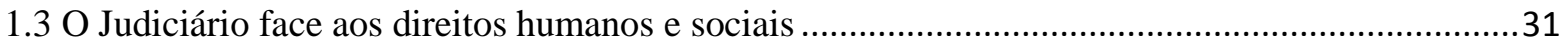

1.4 A consolidação dos direitos sociais nas constituintes brasileiras: o surgimento da educação

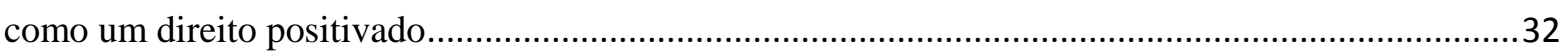

1.5 A educação como direito fundamental social na Constituição Brasileira de 1988 .........................39

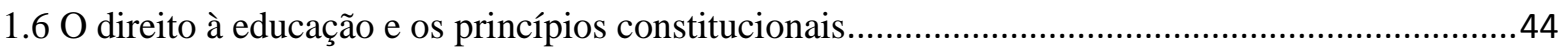

\section{A EDUCAÇÃO DENTRE OS DIREITOS HUMANOS: COMPETÊNCIAS E}

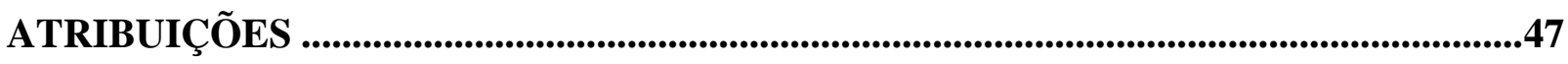

$2.1 \mathrm{O}$ processo de internacionalização dos direitos humanos ..........................................................48

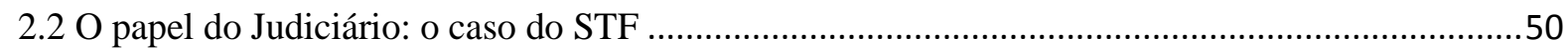

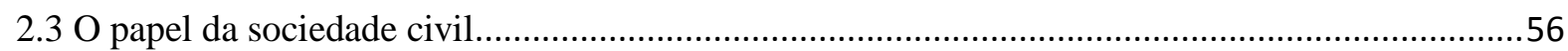

3 A EDUCAÇÃO E OS PACTOS INTERNACIONAIS...........................................62

3.1 A educação nas normas e planos de educação nacionais ..............................................................66

\section{A EDUCAÇÃO NOS RELATÓRIOS BRASILEIROS SOBRE DIREITOS} HUMANOS ECONÔMICOS, SOCIAIS, CULTURAIS E AMBIENTAIS ..........................84

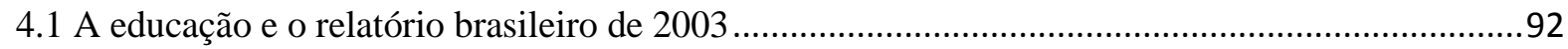

4.1.1 Aspectos gerais da educação no relatório brasileiro de 2003 …………….................................93

4.1.2 Aspectos específicos sobre o trabalho de campo: a missão educacional no Ceará ......................98

4.2 O relatório de 2004 sobre a violação dos direitos educativos nos estados de Alagoas e

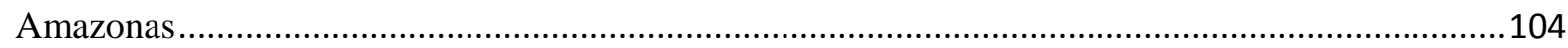

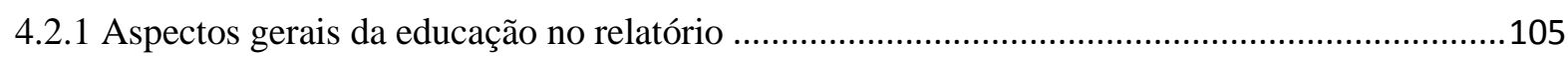

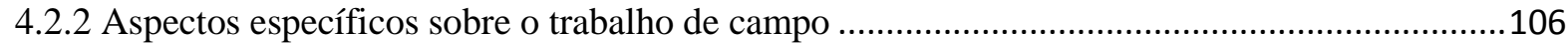

4.3 O relatório de 2007 sobre a violação dos direitos educativos da Comunidade do Complexo do Alemão 
4.3.1 Aspectos gerais da educação no relatório

4.3.2 Aspectos específicos sobre o trabalho de campo .............................................................. 114

$4.4 \mathrm{O}$ relatório sobre a educação nas prisões brasileiras ........................................................123

4.4.1 Aspectos gerais da educação no relatório

4.4.2 Aspectos específicos sobre o trabalho de campo da missão realizada em estabelecimentos prisionais desde outubro de 2008 até abril de 2009

4.4.3 A missão da Relatoria nas unidades prisionais de Pernambuco 132

4.4.4 A missão da Relatoria nas unidades prisionais de São Paulo. 135

4.4.5 A missão da Relatoria nas unidades prisionais do Rio Grande do Sul. 138

4.4.6 A missão da Relatoria nas unidades prisionais do Pará 139

4.4.7 A missão da Relatoria na unidade prisional do Distrito Federal . 140

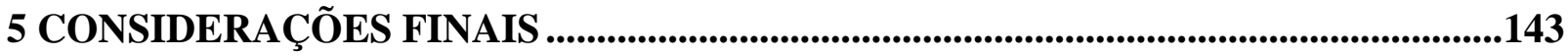

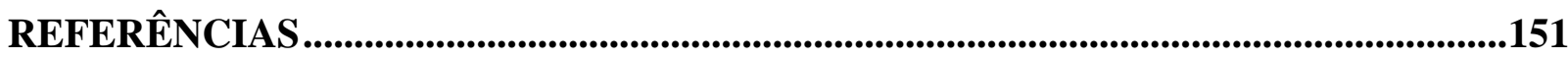

APÊNDICE A - Informações gerais do relatório brasileiro sobre os DhESC/2003

APÊNDICE B - Principais informações sobre a educação contidas no relatório brasileiro sobre os DhESC/2003

APÊNDICE C - Principais informações sobre a educação contidas no informe sobre os DhESC/2004.

APÊNDICE D - Principais informações contidas no relatório de 2007 sobre a violação dos direitos educativos da Comunidade do Complexo do Alemão. 162 APÊNDICE E - Principais informações contidas no relatório sobre a educação nas prisões brasileiras 


\section{INTRODUÇÃO}

O objetivo desta pesquisa é investigar a questão da efetivação da educação como um direito humano. Para tanto, procurou-se demonstrar os problemas existentes na concretização dessa promessa estatal, que, como um direito fundamental, é pertencente a todos os cidadãos, dado o seu caráter eminentemente social.

Para o seu desenvolvimento, trabalhou-se com uma ampla revisão bibliográfica, analisando-se a questão da educação como um direito humano no marco dos relatórios da Plataforma Brasileira de Direitos Humanos Econômicos, Sociais, Culturais e Ambientais (DhESCA) em matéria de educação. Esse material serviu como base para confrontar a lenta evolução histórica brasileira da universalização da educação com a urgente necessidade de consolidação desse direito fundamental.

Além disso, justifica-se a escolha dos relatórios da Plataforma DhESCA em educação pela sua grande importância na consolidação de nosso Estado Democrático de Direito. Isto porque, além de apresentarem dados relevantes para a análise da situação da educação brasileira, constituem um importante ponto de partida para a efetivação deste direito, representando um grande marco para nossa história, devido à concretização de uma nova relação entre o governo e a sociedade civil, resultando na produção de um diálogo produtivo.

A escolha do objeto de pesquisa deveu-se a minha constante preocupação com a questão, por ter dificuldade em visualizar um futuro promissor em matéria educacional, garantidor de uma educação plena e eficaz para todos os cidadãos. Porém, essa preocupação sempre foi motivada pela certeza de que o início de uma possível solução seria, genericamente, o respeito aos direitos humanos, devendo a educação ser devidamente valorizada como tal.

Assim, a educação sempre foi motivo de meu interesse, devido a sua fundamental importância, na medida em que este direito representa uma garantia primária para a consolidação de uma série de outros direitos dos cidadãos, além de constituir-se em um direito em si.

Diante da relevância dos direitos sociais e com vistas a atingir a questão de fundo do presente trabalho, um dos pontos que desafia a própria efetividade desses direitos é a necessidade de consolidá-los como direitos fundamentais. 
A incorporação dos direitos sociais como direitos fundamentais advém da própria interpretação constitucional e assim também é permitida pela própria evolução dos direitos sociais ao longo de nossa história.

Os direitos sociais ganharam lugar de destaque no Título II da Constituição Federal, referente aos direitos e garantias fundamentais da pessoa humana. Este lugar ocupado pelos direitos sociais dentro de nossa Constituição permite, por exemplo, a tutela coletiva e a sua defesa mediante a participação de entidades associativas e do Ministério Público.

Ademais, não se deve entender como fundamentais apenas os direitos sociais elencados nos artigos $6^{\circ}$ a 11 da nossa Constituição, mas todos aqueles periféricos em relação a ela, sem os quais os direitos sociais não seriam efetivos na vida cotidiana.

Verifica-se, portanto, que há uma necessidade premente de se consolidar os direitos sociais dentro do próprio espaço contido na hermenêutica constitucional, a fim de que alguns direitos, tais como o direito à educação, estejam suficientemente fortalecidos para se tornarem efetivos em nossa realidade.

Por outro lado, o desenvolvimento da pesquisa revela, também, que a educação, num sentido mais amplo, importa em formação e socialização do indivíduo, possuindo, portanto, um caráter político, devido a sua importância fundamental para a disseminação da cultura e sua penetração através das gerações e sua importância para a formação do tipo de cidadão/cidadã necessário para a sociedade. A análise será centrada, num sentido mais restrito, na educação que se realizaria privilegiadamente no espaço escolar.

Para que a educação seja compreendida como direito humano, com a função social de garantir a todos o letramento e o saber ${ }^{1}$, assim como a possibilidade de uma participação plena na vida pública, ainda é preciso que diversos desafios sejam enfrentados, tais como: a questão do acesso e da permanência na escola; a possibilidade de constituição de um convívio que trate - democraticamente - dos constantes conflitos existentes dentro do próprio ambiente escolar; a superação do preconceito e das crenças que se formaram no pensamento educacional brasileiro sobre a função social da escola ${ }^{2}$; o maior

1 “[...] A partir de então, as reformas e os projetos educacionais e o entendimento das dificuldades crônicas de escolarização que assolam grande contingente dos alunos da rede pública de ensino têm-se norteado por uma longa paráfrase de uma concepção fundamental: os pobres são menos capazes, mais ignorantes, mais propensos à delinqüência - seja por motivos constitucionais seja por deficiências no ambiente familiar, lido em chave moralista -, motivo pelo qual, no discurso oficial, uma das concepções mais pregnantes da função social da escola, ao longo da história do pensamento educacional brasileiro, é, explícita ou implicitamente, a de prevenção da criminalidade, o que praticamente anula a escola como instituição que tem o dever de garantir o direito de todos ao letramento e ao saber." (PATTO, 2007, p. 245).

2 "Mais de cem anos depois, a continuidade desses mitos sobre o povo e sobre a função social da escola é prova impressionante da força do preconceito, que resiste ao conhecimento alcançado a respeito da 
comprometimento dos governos e da administração pública em geral com os recursos destinados à educação; a erradicação dos demais conflitos e violações de direitos humanos que impossibilitam a efetivação da educação, devido ao caráter indivisível e interdependente desses direitos, conforme será melhor descrito a seguir.

No que tange à afirmação da educação enquanto direito humano - que implica na percepção de uma profunda ideia de igualdade e dignidade -, este direito constitui também um processo de consolidação da própria noção de cidadania, que envolve a capacidade do homem compreender e estar a par - e assim participar e propor - dos problemas políticos, sociais, econômicos, ambientais e culturais, tanto de sua comunidade local como do País.

Por ser um direito humano, tal qual preceitua o artigo 26 da Declaração Universal dos Direitos Humanos ${ }^{3}$, além de direito em si, constitui-se como a base para a realização de diversos outros direitos.

Como uma legítima forma de acesso a uma série de outros direitos, o direito à educação possibilita, por exemplo, a conquista do exercício da liberdade de expressão, do acesso à informação para o gozo dos direitos civis e políticos, bem como dos direitos sociais e econômicos.

Porém, no que diz respeito à questão da universalização da educação, tem-se uma situação complexa exemplificada pelas suas formas/funções em nossa realidade atual (SCHILLING, 2008, p. 276-277):

[...] subjaz, sob esta concepção da função da escola, tanto a idéia de que a educação para 'todo(a)s', ou das massas, deve ser principalmente uma tarefa de moralização por conta da ideia de que os pobres (o povo) são menos capazes de aprender e mais propensos à criminalidade, como uma certa justificativa de escolas separadas, escolas para as elites, que ensinarão, e escolas para o povo, que terão outros objetivos. Uma frase recorrente, ouvida em diversas pesquisas sobre os fins da educação, revela que, talvez, a educação escolar esteja sendo vista como sinônimo de um lugar de proteção para as crianças, de deixá-las distantes das ruas, vistas como lugares de perigo. Ou, então, a educação escolar ainda é vista como uma ponte para a conquista de um lugar no mercado de trabalho. Quão distantes estamos da compreensão da escola como uma instituição que tem o dever de garantir o direito de todos ao saber, ou seja, da educação como um direito humano.

complexidade dos determinantes do crime e da própria criminalização das condutas de pobres e negros como prática de natureza política. Na atual conjuntura de desemprego e de permanência da barbárie que sempre marcou a relação de classes no país, está aberta a porta à destituição da escola como instituição de ensino e à transformação dela em lugar de detenção maquiada dos filhos dos pobres e de violência sem precedentes." (PATTO, 2007, p. 245).

3 "2. A instrução será orientada no sentido do pleno desenvolvimento da personalidade humana e do fortalecimento do respeito pelos direitos humanos e pelas liberdades fundamentais. A instrução promoverá a compreensão, a tolerância e a amizade entre todas as nações e grupos raciais ou religiosos, e coadjuvará as atividades das Nações Unidas em prol da manutenção da paz ". 
Outro ponto fundamental para se entender os entraves à efetividade da educação enquanto um direito humano está em se combater a diferença dentro do próprio sistema escolar, pois é lá onde se operam constantemente classificações que produzem essas diferenças, transformando-as em desigualdades, contrariando a proposta ideal de uma educação igualitária para todos (SCHILLING, 2008).

Beisiegel (1986, p. 409-410), ao tratar da exclusão e da discriminação na escola hoje e em tempos passados, assevera que:

\begin{abstract}
[...] no passado, a exclusão escolar das populações subalternas aparecia sob a forma simples e direta da inexistência de possibilidades de acesso aos setores mais decisivos do ensino. Hoje, o processo de exclusão continuaria operando eficazmente, mas sob formas menos transparentes. A generalização das oportunidades de acesso à escola comum e o alargamento das possibilidades de ingresso nos degraus superiores da escolaridade estariam somente disfarçando a persistência dos mecanismos de discriminação.

[...] Em outras palavras, embora a extensão das oportunidades escolares e a transformação formal do sistema de ensino não tenham de fato produzido conseqüências mais significativas na situação de classe da grande maioria dos habitantes, ao integrarem o aparato ideológico dissimulador do real estariam na verdade consolidando a própria desigualdade que pretendiam combater.
\end{abstract}

Um dos grandes desafios que se impõe à educação, quando compreendida como um direito humano é exatamente refutar esses sistemas de exclusão que habitam os ambientes escolares. Isso porque, como vimos, toda exclusão operada na escola vai repercutir de forma igualmente negativa em todos os outros setores da vida social dos indivíduos.

Dubet (2003, p. 34) analisa os mecanismos de exclusão e as desigualdades produzidas na escola e irradiadas para a sociedade, concluindo que:

[...] é a própria escola que opera as grandes divisões e as grandes desigualdades. $\mathrm{Ou}$ seja, as igualdades sociais comandam diretamente a entrada nas carreiras escolares e os próprios processos escolares produzem essas desigualdades que, por sua vez, reproduzem as desigualdades sociais. O sistema está fechado. Abrindo-se, a escola não é mais "inocente", nem é mais "neutra"; está na sua "natureza" reproduzir as desigualdades sociais produzindo as desigualdades escolares.

No entanto, esse desafio não é simples, dada a grande resistência à não efetivação desse direito, tanto do ponto de vista social - dado o sistema de exclusão operado nos próprios ambientes escolares - quanto do ponto de vista jurídico - excesso de rigor formal construído pela doutrina e jurisprudência.

Assim sendo, pretendeu-se produzir uma reflexão atual e concreta sobre o tema proposto, procurando rever o debate a partir da análise da literatura desenvolvida na área e, 
sobretudo, da análise dos relatórios da Plataforma Brasileira de Direitos Humanos Econômicos, Sociais, Culturais e Ambientais (DhESCA) em matéria de educação.

Em contrapartida, foram ressaltados os problemas existentes na entrega da contraprestação estatal, bem como a necessária participação de vários atores, desempenhando diversos papéis sociais, tais como os operadores do direito, as organizações não governamentais, os três poderes e a sociedade civil como um todo para a efetiva realização desse direito.

Entendeu-se fundamental o aprofundamento da análise dos relatórios da Plataforma DhESCA, para uma completa identificação da situação brasileira. Com isso, foram abordados os diversos problemas existentes, tais como a questão do financiamento e as diversas tentativas isoladas de construção de uma igualdade dos direitos sociais.

$\mathrm{O}$ ponto de partida para a abordagem referente à efetivação da educação como direito humano deverá estar ligada a dois elementos principais: o acesso e a permanência. De acordo com Beisiegel (1986, p. 401),

[...] não obstante os grandes números de crianças que não chegam a ingressar na escola, o mais grave desafio que ora se coloca para o sistema escolar consiste na curta permanência dos alunos no ensino comum. As análises da situação educacional apontam a denominada "evasão escolar" como o principal indicador das deficiências do ensino.

O primeiro elemento, portanto, diz respeito ao próprio direito, que está intimamente relacionado ao processo de democratização progressiva e universalização da educação escolar brasileira, e o segundo refere-se ao aluno dentro do sistema escolar (SCHILLING, 2008, p. 275).

Ambos os elementos constituem desafios permanentes para se alcançar os objetivos da educação, dentro de um contexto em que a formação da cultura educacional brasileira sempre apontou, ao longo da história, a educação escolar por um viés de prevenção da criminalidade, de um lado, e de outro, como única forma de se garantir um espaço dentro do mercado de trabalho, limitando o papel da escola a uma função instrumental (dar o mínimo necessário para que esse ingresso se efetive) (PATTO, 2007, p. 234).

Analisando-se os relatórios da Plataforma DhESCA sobre como está sendo concretizada a educação no país, chega-se aos principais problemas surgidos na entrega dessa contraprestação estatal.

A necessidade de consolidação da educação como direito humano é evidente, pois constitui um direito fundamental de ordem social e, portanto, pertencente a todos os 
cidadãos. Isso explica a importância do Estado em cumprir o seu papel corretamente, garantindo que esse direito seja alcançado por todos, sem exceção.

Por outro lado, faz-se necessário um esforço conjunto de toda a sociedade civil para que o direito à educação se torne efetivo, desde os três poderes até o terceiro setor, passando por todos os cidadãos que igualmente são detentores desse direito, tendo cada qual um papel complementar e de fundamental importância em sua concretização.

Dessa forma, para que sejam superadas determinadas concepções que se formaram ao longo da história da educação brasileira - a escola como instituição preventiva da criminalidade, lugar de guardar crianças, ou apenas como meio para o alcance de uma vaga no mercado de trabalho -, é preciso que se garanta a todos o acesso à escola e a uma educação de qualidade, bem como se consiga vencer o obstáculo da permanência, realizando assim seu desafio de que todos e todas tenham um acesso igualitário ao patrimônio cultural e científico da humanidade.

Assim sendo, toda ação que tenha o objetivo de fazer com que o direito à educação se torne efetivo e concreto, deverá passar pela administração dos conflitos surgidos entre a igualdade preconizada por esse direito e a desigualdade produzida e presente dentro da escola.

$\mathrm{Na}$ presente pesquisa pretendeu-se, assim, reforçar a importância da efetivação da educação como direito humano, para que através dele os cidadãos possam alcançar a plena realização de outros direitos.

Com a análise dos relatórios nacionais referentes à matéria, torna-se possível a visualização de um panorama atual da questão, permitindo um maior enfrentamento dos problemas existentes nesse campo a partir dessas constatações.

A revisão bibliográfica referente ao assunto traz a possibilidade de serem discutidas possíveis alternativas para os problemas existentes, num contexto onde se deve levar em conta noções de democracia participativa e de cidadania: a atuação conjunta dos diversos atores sociais visando à concretização de um direito pertencente a todos, dado seu caráter eminentemente social.

Com os resultados obtidos a partir da análise dos relatórios nacionais de como se opera a educação, acredita-se ser possível exigir do Estado atitudes concretas e efetivas para a minimização dos problemas do acesso e da permanência dos alunos na escola, bem como a redução das desigualdades existentes dentro do próprio ambiente escolar.

Assim sendo, o primeiro tópico desta dissertação traz as principais discussões da pesquisa, tendo sido dividido em subtópicos, a fim de torná-lo mais didático, organizando 
os debates de acordo com o contexto em que estão inseridos. Analisando o panorama geral dessas discussões, percebe-se que existem inúmeros conflitos e dificuldades que impedem a realização plena e efetiva do direito à educação até os dias atuais.

Isto se deve a determinados fatores históricos que revelaram as tensões às quais os direitos humanos em geral sempre estiveram submetidos, na maioria das vezes advindas das relações tortuosas entre o Estado e a sociedade.

$\mathrm{Na}$ sequência, este tópico inaugural apresenta uma importante análise do processo de incorporação dos direitos sociais como fundamentais no âmbito da Constituição Brasileira.

Para tanto, utiliza-se como parâmetro de análise os direitos sociais ao longo da história, marcados por forte resistência à sua evolução, inclusive durante o processo de sua consolidação nas constituintes brasileiras.

Afora as tensões vivenciadas pelos direitos sociais, decorrentes de maiores privilégios em favor dos interesses privados, houve a conquista de uma posição de destaque daqueles dentro da Constituição Federal Brasileira de 1988, apesar dos óbices à sua efetivação persistirem até os dias atuais.

Outra discussão presente neste tópico trata especificamente desta questão da efetividade dos direitos sociais, deflagrando o problema da negação ao reconhecimento dos direitos sociais como direitos fundamentais.

Faz-se uma análise das errôneas interpretações doutrinárias das quais se utilizam os operadores do direito para suprimirem a importância da aplicação destes direitos, apontando-se como viável à sua efetivação a interpretação sistemática do ordenamento constitucional, que considera o direito à educação como direito fundamental.

Em seguida, ressalta-se a importância do Judiciário perante a correta interpretação dos direitos fundamentais, e a consequente efetividade dos direitos sociais.

No entanto, sem desmerecer as importantes conquistas e evolução do Poder Judiciário, o que se revela é uma forma retrógrada de solução dos conflitos sub judice, onde o excesso de rigor formal impede a verdadeira efetivação dos direitos na resolução dos litígios.

Esta grande resistência a interpretações mais flexíveis em relação aos direitos humanos e sociais acaba demonstrando a própria negação desses direitos, como forma de privilegiar interesses particulares e ambições políticas, mantendo-se o poder e o controle sobre a própria evolução da sociedade do ponto de vista coletivo. 
O quarto subtópico, por sua vez, traz os principais momentos históricos do surgimento da educação como um direito positivado, evidenciando-se que o contexto em que esse direito estava inserido era o mesmo do processo de consolidação dos direitos sociais nas constituintes brasileiras. Com isso, evidencia-se o reconhecimento da educação como um direito público subjetivo na Constituição Federal de 1988, como resultado de lutas e pressões históricas advindas de momentos anteriores.

Destaca-se o trabalho de Maria Francisca Pinheiro (1996), que apresenta a atualidade dos debates sobre o público e o privado, revelando ser este um conflito antigo, mas que possui até hoje forte influência em diversos setores da sociedade, dentre eles, a educação, que fora o objeto de pesquisa investigado pela autora.

Assim sendo, a referida autora demonstrou quais foram os problemas e dificuldades enfrentados pelos grupos políticos que participaram da consolidação da atual Constituição Brasileira em matéria de educação.

O subtópico seguinte traz a educação como parte integrante dos direitos fundamentais na Constituição Federal de 1988, fazendo-se uma análise de seu significado dentro do ordenamento, e ressaltando-se a importância de uma correta interpretação no momento de sua aplicação no caso concreto, com vistas a torná-lo eficaz.

O final deste primeiro tópico demonstra a intrínseca relação existente entre o direito à educação e os princípios constitucionais, em especial o princípio fundamental republicano da dignidade da pessoa humana.

Além disso, demonstra-se que este direito também é caracterizado, por sua importância, como um serviço público essencial, cuja responsabilidade direta por sua manutenção é atribuída ao Estado.

O segundo tópico também foi desenvolvido mediante divisão em subtópicos, onde se quis demonstrar que a educação encontra-se fundamentalmente inserida no contexto dos direitos humanos.

Destaca-se a importância deste caminho de reconhecimento do direito à educação para que se revele a igualdade de oportunidades, o exercício da cidadania e a conquista de outros direitos por parte dos cidadãos.

Inicialmente, traz-se o histórico do processo de internacionalização dos direitos humanos, como forma de se demonstrar a ampla abrangência dos compromissos internacionais assumidos pelo País para a proteção deste direito no aspecto formal, e o disparate existente com relação à sua aplicação em âmbito nacional. 
Adiante é abordado o dilema anteriormente referido através da análise da importância do Poder Judiciário, em especial o Supremo Tribunal Federal, cujo papel é o de garantir e zelar pela guarda dos direitos estampados na Constituição Federal.

A partir disso, constata-se que existem algumas contradições refletidas nos julgados advindos do STF, onde esta Corte acaba por não revelar efetivamente o seu melhor desempenho no cumprimento das funções que lhe foram atribuídas dentro de nosso sistema federativo, dentre elas o compromisso assumido pelo Estado perante as obrigações internacionais.

Dentro desse contexto da órbita internacional de proteção de direitos, o final deste tópico discute o papel da sociedade civil como forma de pressionar o Estado e seus Poderes a garantir o cumprimento de suas obrigações assumidas, principalmente no que se refere ao respeito e não violação aos direitos humanos.

Destaca-se a atuação exemplar das organizações não governamentais, cuja maneira de atuação na busca de garantia destes direitos tem se mostrado inovadora, como é o caso do exemplo citado referente ao "litígio estratégico e paradigmático".

O terceiro tópico, por sua vez, elenca os principais pactos internacionais onde a educação encontra-se inserida. Ao tratar-se do Pacto Internacional dos Direitos Econômicos, Sociais e Culturais (Pidesc), destaca-se a obrigatoriedade de elaboração de relatórios pelos Estados-membros, que objetivam descrever as providências tomadas por eles, com vistas a concretizar os direitos ali previstos, bem como enunciar as dificuldades encontradas no cumprimento de suas obrigações decorrentes deste documento.

Apesar do reconhecimento da educação no âmbito internacional por parte de todas as Nações, mediante a assinatura de Tratados que asseguram este direito, constata-se que o Brasil não tem honrado à altura este compromisso assumido internacionalmente, por conta das diversas violações aos direitos sociais ainda muito comuns em nossa realidade.

A discussão seguinte traz a educação sob o ponto de vista das normas e planos de educação nacionais. Primeiramente, faz-se uma análise dos principais pontos (altos e baixos) da Lei de Diretrizes e Bases da Educação Nacional. Em seguida, passa-se, da mesma forma, à análise do Plano Nacional de Educação, que, na visão de Ghiraldelli Júnior (2006, p. 196-198), possui a grande qualidade de trazer à tona a real situação da educação no Brasil.

Além disso, este tópico faz uma abordagem da educação no Programa Nacional de Direitos Humanos, desde a sua primeira versão até a atual, constatando-se que a educação 
não ocupa ainda o lugar de direito humano propriamente dito, mas apenas como instrumento para a conquista de outros direitos.

Como exemplo de legislação que considera a educação como um direito humano, em seu primeiro subitem, cita-se a Lei Geral sobre educação do Uruguai, analisando-se algumas importantes passagens deste documento onde esta característica encontra-se bastante clara e definida.

Nela, não há margem para interpretações dúbias ou qualquer outro tipo de dificuldade para sua aplicação no caso concreto, como é o caso ocorrido com frequência no Brasil. Na lei uruguaia, os direitos humanos são tidos como referência para o exercício do direito à educação, sendo que o princípio da gratuidade garante o cumprimento efetivo da educação e da universalização do acesso e da permanência dos indivíduos no sistema escolar, estes, por sua vez, os principais problemas existentes no Brasil.

Por outro lado, ao analisar-se o Programa de Direitos Humanos do Estado de São Paulo, percebe-se novamente uma maior valorização dos direitos civis, em detrimento dos direitos sociais. Já no Plano Municipal de Direitos Humanos da Cidade de São Paulo, os direitos econômicos, sociais e culturais aparecem como condições essenciais de existência para os direitos civis e políticos, constituindo, assim, um grande diferencial com relação aos outros.

No caso das expectativas em torno da formulação do Plano de Educação da Cidade de São Paulo, percebe-se que os debates realizados até agora trazem uma maior preocupação em tratar a educação como um direito humano, pretendendo não limitar a concepção de educando apenas aos grupos específicos.

Destacou-se neste tópico, ainda, a importância da atuação conjunta de todos os setores da sociedade, a fim de se concretizar a plena efetivação do direito à educação. Como exemplo de importante atuação neste sentido, citou-se o trabalho desenvolvido pela organização sem fins lucrativos denominada "Ação Educativa".

A proposta do quarto tópico foi efetuar uma análise da educação diante dos relatórios produzidos pela relatoria dos Direitos Humanos Econômicos, Sociais, Culturais e Ambientais (DhESCA).

Para orientar a investigação do primeiro ponto constante neste tópico, utilizou-se como principal referencial bibliográfico a publicação feita em Recife no ano de 2003, denominada: "Relatório Brasileiro sobre Direitos Humanos Econômicos, Sociais e Culturais" (RELATÓRIO..., 2003). Este documento foi produzido pela Plataforma DhESCA, como parte do projeto dos relatores nacionais neste âmbito. Constata-se que um 
dos organizadores deste relatório foi Jayme Benvenuto Lima Júnior (2001), cujo referencial bibliográfico também fora objeto de pesquisa desta dissertação.

De acordo com o item específico constante no relatório sobre o direito humano à educação, o trabalho foi desenvolvido em 2003 por Sérgio Haddad, relator nacional para o direito humano à educação, e contou com a assessoria de Mariângela Graciano (2005), cuja dissertação de mestrado também foi utilizada como referência na presente investigação.

Segundo o que consta na apresentação do referido item do relatório (RELATÓRIO..., 2003, p. 201):

[...] este relatório procura avaliar como a Educação no Brasil tem sido tratada sob o ponto de vista dos direitos humanos. Aponta, inicialmente, a que normas legais estão referidos tais direitos, analisa o contexto educacional dos últimos anos, descreve os resultados de uma missão que esta Relatoria realizou à cidade de Fortaleza, Estado do Ceará, e estabelece recomendações e conclusões.

A primeira discussão desta parte apresenta os aspectos gerais da educação neste relatório, analisando o tratamento dado à educação até aquele momento, em face dos direitos humanos.

Sobre o ensino brasileiro trazido neste relatório, percebe-se que houve uma tentativa de redução da desigualdade educacional, pois nos últimos dez anos ocorreu quase que a total universalização do ensino fundamental, apresentando um grande crescimento do número de vagas, além de um grande avanço relativo ao atendimento no ensino médio em geral.

Por outro lado, as fragilidades do sistema educacional restaram evidenciadas quando o relatório demonstrou a precariedade relativa à qualidade do ensino, que resulta em altos índices de evasão e repetência, gerando uma nova forma de exclusão, qual seja, a falta de permanência dos educandos na escola para completar sua escolarização, além dos limites para a expansão desse atendimento e as desigualdades de diversas ordens (como por exemplo, racial e de gênero) que impedem esse processo.

Outro grave problema apontado diz respeito aos desvios dos recursos destinados à educação para privilegiar interesses pessoais, por conta da existência de uma administração pública corrompida e descompromissada.

$\mathrm{Na}$ discussão seguinte foram realçadas as principais constatações relativas à missão educacional no Ceará, motivada pelo recebimento de denúncias sobre violações ao direito à educação da população daquela localidade, cujos principais temas também dizem respeito a problemas de acesso e qualidade do ensino. 
O subtópico posterior, por sua vez, traz duas subdivisões que se referem à missão da Relatoria Nacional para o Direito Humano à Educação, realizada nos Estados de Alagoas e Amazonas. A primeira parte teve como finalidade abordar os aspectos gerais da educação tratados no referido relatório, enquanto que a segunda tratou de analisar os aspectos específicos relacionados à pesquisa de campo.

Em linhas gerais, concluiu-se com a pesquisa que, apesar das violações à educação apresentarem algumas especificidades, revelam situações frequentes no país relativas à inefetividade do direito humano à educação diante dos obstáculos que impossibilitam a sua efetivação universal, tais como a corrupção na administração pública, o desrespeito às características culturais, regionais ou das diferentes etnias - no caso, as populações indígenas -, e a insuficiente fiscalização dos recursos públicos.

O subtópico seguinte teve como finalidade apresentar os resultados obtidos com o trabalho de campo da Relatoria do Direito Humano à Educação relativo às frequentes violações dos direitos educacionais e outros direitos humanos numa das principais zonas de conflito armado da cidade do Rio de Janeiro: o Complexo do Alemão.

Esta parte chamou a atenção para a intrínseca relação entre educação e segurança pública, pois em áreas conflagradas, onde a sensação de medo e insegurança prevalecem, a educação não se realiza. Trata-se, portanto, de um perfeito exemplo que corrobora uma das principais características dos direitos humanos, qual seja, a sua indivisibilidade.

Com isso, reitera-se a necessidade de diálogo e interação entre os diversos setores da sociedade e a criação de políticas públicas integradas, com vistas a se erradicar o não atendimento e/ou a violação a qualquer um dos direitos do ser humano.

Da mesma forma, o próximo subtópico contém os relatos sobre a educação no sistema prisional brasileiro, que, apesar de apresentar alguns avanços, como a aprovação de lei para a remição de pena por estudo, apresenta descontinuidade em sua realização, tendo em vista a precariedade das instalações e condições de alojamento dos detentos, a violência empregada por policiais e agentes penitenciários contra os presos, bem como a negociação deste direito por parte dos agentes do Estado para a manutenção da ordem disciplinar.

Em suma, a dissertação como um todo constatou a lenta efetivação histórica no Brasil da educação como direito humano, os problemas existentes a esse respeito, como por exemplo, a questão do seu escasso financiamento. Por outro lado, fez-se também a demonstração existente da tentativa de construção de uma igualdade dos direitos sociais. 
Por fim, o objeto central da pesquisa fora retomado para problematizar novamente esta questão da efetivação do ponto de vista concreto. Com isso, o intuito foi reforçar os dilemas vividos pela educação no Brasil e, a partir daí, pontuar alguns desafios para a sua consolidação enquanto um direito humano.

$\mathrm{Na}$ parte reservada às considerações finais há o retorno a este objeto central de pesquisa, para que nos momentos finais, este debate seja reavivado com o confronto dos resultados da análise efetuada através dos relatórios, leis e referências consultados. 


\section{CARACTERIZAÇÃO GERAL DA EDUCAÇÃO COMO DIREITO HUMANO: CONSIDERAÇÕES PRELIMINARES}

O presente tópico apresentará o panorama atual dos diplomas legais nacionais e internacionais onde está inserida a educação, a fim de se refletir sobre a necessidade de consolidá-la como um direito humano.

Para tanto, faz-se necessário recuperar alguns episódios marcantes na história dos direitos, tais como: a evolução dos direitos sociais, o surgimento da educação como um direito positivado, e a relação deste com os direitos sociais.

Isso porque, como bem ressaltado por Romualdo Portela de Oliveira (1995, p. 41), a educação constitui um pré-requisito essencial para o exercício dos demais direitos que compõem a cidadania e, por essa razão, ela é considerada até mais que um direito social, formando a própria estrutura da democracia. Não sem motivo, ainda, a educação está presente nos ordenamentos de todos os países e é reconhecida hoje como um direito de todos.

Porém, para se entender as dificuldades na efetivação desse direito fundamental e na sua consolidação como um direito humano é necessário considerar, primeiramente, que a história dos direitos humanos em geral sempre foi marcada por tensões envolvendo os seus principais agentes, representados, de um lado, pelo Estado, e de outro, pela sociedade.

\subsection{Os direitos sociais na concepção de direitos fundamentais}

Do ponto de vista constitucional brasileiro, tem-se que a incorporação dos direitos sociais como direitos fundamentais também encontrou e ainda encontra resistência por parte dos aplicadores do direito, por ser um processo que advém da própria interpretação sistemática do ordenamento constitucional e também da lenta evolução dos direitos sociais na história.

O processo de consolidação dos direitos sociais nas constituintes brasileiras assemelha-se ao processo vivenciado pela Europa, em que os direitos civis tiveram um amplo espaço no século XVIII, os direitos políticos no século XIX e os direitos sociais apenas ocuparam seu lugar durante o século XX (CURY; HORTA; FÁVERO, 1996, p. 5). 
Maria Francisca Pinheiro, em seus estudos sobre o público e o privado (1996, p. 258), faz uma importante ressalva a respeito da depreciação dos interesses sociais perante os individuais, o que muito explica em relação ao processo de consolidação tardio dos direitos sociais no Brasil, incluindo-se, entre eles, o direito à educação:

\footnotetext{
[...] no Brasil, após a década de 30, concomitante ao processo de intervenção do Estado na esfera econômica, como principal agente do desenvolvimento, ocorreu uma tendência de privatização da esfera pública. Mas o processo de interpenetração entre essas esferas caracterizou-se por um duplo prejuízo da esfera pública, pois tanto a intervenção do Estado na área econômica quanto do setor privado na esfera pública favoreceram primordialmente interesses privados e não públicos.

$\mathrm{Na}$ área educacional o conflito público-privado é antigo e remonta aos primórdios dos anos 30. Este confronto irá se manifestar através de uma disputa entre a escola pública e a escola privada pela hegemonia no campo do ensino.
}

Apesar de lenta, a evolução dos direitos sociais permitiu com que esses direitos ganhassem lugar de destaque no Título II da Constituição Federal, referente aos direitos e garantias fundamentais da pessoa humana, não podendo ser rebaixados de nenhuma forma, por possuírem tal status.

Assim sendo, a admissão desta classificação permitiu uma maior efetividade de sua proteção, já que a tutela coletiva e a sua defesa mediante a participação de entidades associativas e do Ministério Público, por exemplo, constituem instrumentos jurídicos criados para garantir a proteção desses direitos contra abusos ou violações.

Adotando-se uma interpretação sistemática e teleológica de nosso ordenamento constitucional e não simplesmente literal, e considerando-se os princípios fundamentais do Título I, há que se valorizar não apenas o indivíduo para a formação do Estado Democrático de Direito, mas os valores sociais a ele inerentes, tais como o trabalho e a livre iniciativa. A própria cidadania, que ocupa o artigo $1^{\circ}$, II da Constituição Federal não pode ser encarada como valor meramente individual, mas também social.

Isto porque, devido ao status constitucional que ostentam (direitos fundamentais do Título II), os direitos sociais devem receber o mesmo tratamento dado aos direitos individuais, inclusive no que diz respeito às restrições perante o Poder Constituinte Derivado.

Ademais, não se deve entender como fundamentais apenas os direitos sociais elencados nos artigos $6^{\circ}$ a 11 da Constituição Federal, mas também os princípios referentes a eles, que assumem um papel de destaque, uma vez que se aproximam dos princípios da 
dignidade e da democracia, sem os quais os direitos sociais perderiam o sentido de sua existência.

Apesar dos direitos sociais ocuparem um lugar de destaque dentro de nossa Constituição, existe ainda uma necessidade premente de se consolidar tais direitos a partir da hermenêutica constitucional, a fim de que direitos como à educação, os da Previdência Social e aqueles referentes à saúde e ao trabalho estejam suficientemente fortalecidos para se tornarem realmente efetivos no plano concreto.

\subsection{A problemática da efetividade dos direitos sociais}

Um dos grandes conflitos existentes até hoje em nosso ordenamento é garantir a efetividade dos direitos sociais, para que eles sejam vivenciados na prática pelos cidadãos. E esta problemática questão se inicia com a própria negação do reconhecimento dos direitos sociais como direitos fundamentais.

A partir daí, os operadores do direito retiram-lhe a aplicabilidade imediata, excluindo-os da garantia das cláusulas pétreas. Com isso, tornam-se simples pautas programáticas, ou seja, que dependem de regulação, por meio de normas infraconstitucionais posteriores, e, ainda, submetidas a uma "reserva do possível".

Ingo Sarlet (2006, p. 301-302), ao tratar da importância econômica que ostentam os direitos sociais prestacionais, discorre acertadamente sobre a "reserva do possível" como um relativo limite àqueles:

A partir do exposto, há como sustentar que a assim designada reserva do possível apresenta pelo menos uma dimensão tríplice, que abrange a) a efetiva disponibilidade fática dos recursos para a efetivação dos direitos fundamentais; b) a disponibilidade jurídica dos recursos materiais e humanos, que guarda íntima conexão com a distribuição das receitas e competências tributárias, orçamentárias, legislativas e administrativas, entre outras, e que, além disso, reclama equacionamento, notadamente no caso do Brasil, no contexto do nosso sistema constitucional federativo; c) já na perspectiva (também) do eventual titular de um direito a prestações sociais, a reserva do possível envolve o problema da proporcionalidade da prestação, em especial no tocante à sua exigibilidade e, nesta quadra, também da sua razoabilidade. Todos os aspectos referidos guardam vínculo estreito entre si e com outros princípios constitucionais, exigindo, além disso, um equacionamento sistemático e constitucionalmente adequado, para que, na perspectiva do princípio da máxima eficácia e efetividade dos direitos fundamentais, possam servir não como barreira instransponível, mas inclusive como ferramental para a garantia também dos direitos sociais de cunho prestacional.

Por outro lado, não nos parece correta a afirmação de que a reserva do possível seja elemento integrante dos direitos fundamentais, como se fosse parte do seu 
núcleo essencial ou mesmo como se estive ( $\mathrm{sic}$ ) enquadrada no âmbito do que se convencionou denominar de limites imanentes dos direitos fundamentais. A reserva do possível constitui, em verdade (considerada toda a sua complexidade), espécie de limite jurídico e fático dos direitos fundamentais, mas também poderá atuar, em determinadas circunstâncias, como garantia dos direitos fundamentais, por exemplo, na hipótese de conflitos de direitos, quando se cuidar da invocação - observados sempre os critérios da proporcionalidade e da garantia do mínimo existencial em relação a todos os direitos - da indisponibilidade de recursos com o intuito de salvaguardar o núcleo essencial de outro direito fundamental.

Com isso, a doutrina se enreda num verdadeiro círculo vicioso, tentando dar uma justificativa para modelos políticos e sociais vigentes como resposta às lutas sociais, criando-se polêmicas discussões, como se observa no caso da teoria da reserva do possível. Como visto, esta figura jurídica deve ser interpretada apenas no sentido de constituir por vezes um relativo limite jurídico e fático dos direitos fundamentais, mas nunca como óbice à aplicação e efetividade dos direitos sociais, como pretendem alguns.

Há aqueles que não consideram os direitos sociais como direitos humanos, pois desconsideram sua perspectiva da universalidade, apostando na separação, de um lado, dos direitos sociais e, de outro, dos direitos civis e políticos.

Outro argumento contrário ao reconhecimento dos direitos sociais como direitos humanos refere-se à sua efetividade, diferenciando-se os direitos sociais dos direitos civis e políticos pelo seu caráter programático.

Porém, esse argumento não merece respaldo, uma vez que deseja preservar desigualdades que a própria Constituição pretendeu superar, por conta de uma base de sustentação meramente política.

Isso porque diversos aplicadores do direito, tais como doutrinadores e magistrados, há muito já reconheceram que essa ausência de regulação infraconstitucional não pode ser obstáculo à aplicação desses direitos, pois a maior parte dos direitos sociais continua pendente de regulamentação desde a promulgação de nossa Constituição.

É certo que, mesmo não existindo detalhamento constitucional, certas disposições encontram-se previstas em nossa Carta Magna e devem ser aplicadas mediante uma generosa forma de interpretação constitucional, a fim de suprir essas lacunas. Como exemplo disso, podem ser citados os direitos relativos à previdência, bem como a implementação de diversos serviços públicos a favor dos cidadãos.

Porém, nota-se que corroborando esses posicionamentos meramente políticos, a teoria construiu uma série de obstáculos centrados em três aspectos: a) o conflito dos direitos; b) a concepção funcional dos direitos sociais; c) um excessivo formalismo positivista na interpretação dos direitos fundamentais. 
O primeiro obstáculo refere-se às dificuldades de implementação dos direitos sociais em face das liberdades individuais e da propriedade, que são direitos que justificam a essência do estado liberal.

Nesse sentido, a doutrina sustenta que os direitos sociais, se implementados, violentariam os direitos de caráter liberal, como se aqueles fossem incompatíveis ou excludentes a estes. Isso assim se explicaria, pois se atendidos, apesar das limitações orçamentárias - tal como sustenta a doutrina alemã da "reserva do possível" -, poderiam deflagrar condições sociais e econômicas que pudessem facilmente proporcionar o crescimento de ideologias tais quais a do nazismo, a fim de se salvaguardar o aspecto social em detrimento das liberdades individuais.

O segundo óbice parte da ideia errônea de que existe uma impossibilidade concreta na implementação dos direitos sociais. A partir daí, considera os direitos sociais como se fossem de segunda ordem, ou seja, subsidiários com relação aos direitos civis e políticos.

Outro grande entrave à efetividade dos direitos sociais diz respeito ao formalismo trazido pelo positivismo exacerbado - que entende o direito apenas como um conjunto de normas, acreditando existir apenas o universo abstrato trazido pelas leis -, ignorando que a realidade social e concreta está engendrada diretamente em relações de poder, e que o sistema jurídico deve suprir e melhorar as situações sociais que impedem a efetivação desses direitos.

Não se deve, de igual maneira, admitir que os direitos sociais somente podem ser concretizados em países com economia forte, pois esse argumento em si mesmo representa o jogo de interesses e de poder que se encontra por detrás dos discursos políticos. Isso representa uma ideologia ultrapassada, simplista e comodista de que as desigualdades sociais são fatalidades históricas e inerentes à própria natureza da sociedade humana.

Também se aproveita de uma retórica racional o argumento indesejado que alguns sustentam com base na teoria da "reserva do possível", como se fora este o limite concreto para a efetivação dos direitos sociais.

Porém, da mesma forma, os direitos civis e políticos, para serem efetivados, também necessitam de um alto custo da máquina estatal. Assim, sustentar esta tese implica necessariamente em se admitir que a escassez de recursos públicos ameaça a existência de todos os direitos.

Se assim o fosse, forçoso seria reconhecer que o Direito apenas daria conta de solucionar conflitos em sociedades em que imperasse a igualdade material e absoluta, ou seja, onde não houvesse carências e necessidades quaisquer. 
Por essa razão, deve-se sustentar a existência de uma fundamentação ética capaz de justificar e legitimar o investimento público na proteção de dignidades humanas fragilizadas.

Ocorre que o cerne da problemática do Estado Democrático de Direito é que a garantia da liberdade passou a ser vinculada a condições materiais que a tornem possível como exercício concreto, afastando-nos dos ideais do Estado liberal-democrático, em que os valores sociais básicos estavam insculpidos na liberdade, na propriedade individual, na igualdade, na segurança jurídica e na representação política.

Deve-se destacar que os direitos sociais derivam do princípio constitucional da dignidade da pessoa humana. Com isso, não há distinção de grau entre os direitos sociais e os direitos individuais ${ }^{4}$, pois ambos são componentes desse bem maior. Esse primado constitucional, por sua vez, possui duas faces intimamente interligadas, quais sejam, a liberdade e a igualdade, as quais os direitos sociais jamais poderão se distanciar.

Sobre o valor e efeitos das normas dentro de nosso ordenamento constitucional, Ingo Wolfgang Sarlet (2006, p. 294) considera que:

[...] a exemplo das demais normas constitucionais e independentemente de sua forma de positivação, os direitos fundamentais prestacionais, por menor que seja sua densidade normativa ao nível da Constituição, sempre estarão aptos a gerar um mínimo de efeitos jurídicos, sendo, na medida desta aptidão, diretamente aplicáveis, aplicando-se-lhes (com muito mais razão) a regra geral, já referida, no sentido de que inexiste norma constitucional destituída de eficácia e aplicabilidade.

Com isso, percebemos que apenas a consolidação dos direitos sociais dentro do próprio espaço contido na hermenêutica constitucional permite que estes direitos, inclusive o direito à educação, estejam aptos a produzirem efeitos e aplicação imediata, tornando-os efetivos no ponto de vista concreto.

4 Cita-se como exemplo, em que se percebe nitidamente a correlação entre os direitos individuais e os direitos sociais, a Declaração sobre o Direito ao Desenvolvimento, adotada pela Resolução 41/128, da Assembléia Geral das Nações Unidas, de 4 de dezembro de 1986, cujo artigo 6, 2, prescreve o seguinte: "todos os direitos humanos e liberdades fundamentais são indivisíveis e interdependentes; atenção igual e consideração urgente devem ser dadas à implementação, promoção e proteção dos direitos civis, políticos, econômicos, sociais e culturais". 


\subsection{O Judiciário face aos direitos humanos e sociais}

Um dos agentes diretamente responsáveis pela correta interpretação dos direitos fundamentais constitucionais e pela consequente efetividade dos direitos sociais é o Poder Judiciário.

No entanto, é nítida a dificuldade de aplicação da lei com relação aos direitos humanos e sociais, diante dos conflitos que estão postos perante os nossos tribunais, onde insistentemente seus membros apostam na velha fórmula de solucioná-los através do excesso de ritos e formalismos que atravancam a efetivação dos direitos nos casos concretos.

José Eduardo Faria (1998, p. 95) detectou claramente este problema ao afirmar que

[...] esse tem sido o grande paradoxo dos direitos humanos - e também dos direitos sociais - no Brasil: apesar de formalmente consagrados pela Constituição, em termos concretos eles quase nada valem quando homens historicamente localizados se vêem reduzidos à mera condição genérica de "humanidade"; portanto, sem a proteção efetiva de um Estado capaz de identificar as diferenças e as singularidades dos cidadãos, de promover justiça social, de corrigir as disparidades econômicas e de neutralizar uma iníqua distribuição tanto de renda quanto de prestígio e de conhecimento.

Nota-se uma grande resistência às interpretações mais flexíveis no campo dos direitos humanos e sociais por parte de nosso Judiciário, em que a preocupação em manter o positivismo e o normativismo jurídicos parece revelar uma forma de manutenção de poder e de controle.

Para Faria, há uma constante e sutil negação do direito, com o pretexto de se utilizar uma interpretação dogmática, onde inexistem leis complementares que regulamentem os direitos assegurados pela Constituição. Assim sendo, esses direitos possuem vigência formal, mas são materialmente ineficazes.

Com essa explicação baseada no dogmatismo, encontrou-se um excelente pretexto para se continuar justificando a inefetividade dos direitos sociais aos segmentos da sociedade menos favorecidos.

E com uma Justiça ineficiente para atender esses novos tipos de conflito diferentes daqueles aos quais os tribunais costumam lidar rotineiramente, tais como questões de direito civil, comercial, penal, trabalhista, tributário e administrativo -, 
deflagra-se uma situação de nítida violação a esses direitos sociais, justamente pelo fato de desatendê-los.

É por essa razão que a situação se conduziu à atual crise de legitimidade do Judiciário, que diz respeito desde a sua própria estrutura organizacional como a própria reação da sociedade, caminhando pela sensação de insegurança até a de impunidade diante de suas decisões, não passando despercebido este fenômeno de aplicação seletiva das leis.

Para a erradicação desses problemas, Faria (1998, p. 2000-2001) propõe uma mudança organizacional e institucional do Judiciário, a fim de se alterar a própria essência de nossa obsoleta estrutura processual:

\footnotetext{
[...] em suma: as mudanças registradas no funcionamento da Justiça brasileira, no plano processual e hermenêutico, não podem ser desprezadas por quem luta pela efetividade dos direitos humanos e sociais. Tais mudanças são condição necessária para a expansão dessas lutas. Não são, todavia, condição suficiente. Essas mudanças são apenas o começo, não o fim dessas lutas. Para que possam propiciar a modernização organizacional e institucional do Judiciário, tornando-o apto a enfrentar as novas e complexas situações sociais e a responder de modo eficaz à explosão de demanda por direitos coletivos, difusos e fragmentários, essas mudanças precisam alterar a essência da estrutura processual vigente; alteração essa que, se por um lado certamente implicará algum déficit de certeza e previsibilidade, por outro pode propiciar maior peso à eqüidade nos casos concretos.
}

Sem deixar de lado as inúmeras conquistas alcançadas pelo Judiciário ao longo dos tempos, percebe-se que ainda é preciso haver um projeto jurídico que esteja em consonância com as ambições políticas, a fim de que se faça respeitar os direitos humanos e sociais assegurados formalmente por nossa Constituição.

\subsection{A consolidação dos direitos sociais nas constituintes brasileiras: o surgimento da educação como um direito positivado}

Foi durante o século $\mathrm{XX}$, em meio ao vagaroso processo de consolidação dos direitos sociais nas constituições brasileiras, que surgiu a educação como um direito positivado, e que foi sendo aos poucos incorporado pelas constituições federais, até ser intitulado como "direito de todos e dever do Estado", com o advento da Emenda Constitucional de 1969.

Antes disso, na Constituição de 1934, a educação conquistou um capítulo próprio dentro do título com o mesmo nome, oficializando, pela primeira vez, em seu artigo 149, 
que "a educação é direito de todos e deve ser ministrada pela família e pelos poderes públicos".

Essa condição de "direito de todos" não ocorreu por um mero acaso, mas para suprir a omissão no texto da Constituição de 1891, reforçando-se o momento histórico de renovação que o País vivenciava na esfera educacional.

Foi apenas na Assembleia Constituinte de 1933 que o movimento educacional renovador mostrou sua expressão, permitindo com que a educação passasse a ser reconhecida como um direito, tal como se observa nas palavras de Rocha (1996, p. 125): "No que se refere ao direito à educação, a concepção doutrinária dos renovadores é a de considerar que o Estado moderno constitucional exige que se faça a afirmação da educação como um direito individual".

Sobre as diversas discussões em que a educação esteve envolvida nas constituintes brasileiras, Cury, Horta e Fávero (1996, p. 13-30) prosseguem nesta análise e ponderam que, antes mesmo que o Estado tivesse assumido sua posição de fundamental importância em matéria de educação, também outras instituições tiveram grande participação nesse cenário, como no caso a família, cujo importante papel foi destacado pela Constituição Brasileira de 1934.

Romualdo Portela de Oliveira (1995, p. 68-69) destaca que foi nesta última que a educação foi vista, pela primeira vez, como um direito positivado, e que assim se perpetuou pelas constituições posteriores, embora fosse assegurado, desde a Constituição Imperial de 1824, a gratuidade da instrução primária a todos os cidadãos, a saber:

Título VIII - Das Disposições Gerais e Garantias dos Direitos Civis e Políticos dos Cidadãos Brasileiros

Artigo 179: A inviolabilidade dos direitos civis e políticos dos cidadãos brasileiros, que tem por base a liberdade, a segurança individual e a propriedade é garantida pela Constituição do Império, pela maneira seguinte: [...]

32) A instrução primária é gratuita a todos os cidadãos.

33) Colégios e universidades, onde serão ensinados os elementos das ciências, belas-artes e artes.

Porém, segundo o autor, como a maioria da população, àquela época, era constituída por escravos, a restrição deste direito se dava pela definição de cidadania, predominando o analfabetismo entre a maioria da população, pois não havia interesse e esforço por parte do Poder Público para tornar a educação efetiva a todas as pessoas.

Essa preocupação com o papel do Estado e da família no que diz respeito à tarefa de educar revela uma questão conceitual mais profunda, de uma sociedade que procurava 
descobrir onde se encontravam os pilares de sua formação: na família, no indivíduo ou se haveria, dada uma proposta de nação, a necessidade da intervenção do Estado para a formação de seus cidadãos.

As duas possíveis vertentes para a educação - atribuição particular dos indivíduos/ famílias ou atribuição do Estado (esta discussão permeada pelas tensões provenientes das relações Estado/Igreja Católica, educação laica/confessional) - permaneceram como alvo das discussões presentes na Constituinte de 1946, que trouxe ainda avanços importantes para a sociedade, pois a partir dela houve a inauguração do período onde surgiram as leis de diretrizes e bases.

Com o fortalecimento dos debates sobre educação e desenvolvimento que se iniciaram nos anos de 1950 e adentraram na década seguinte, houve a criação da Lei de Diretrizes e Bases da Educação Nacional e o respectivo Plano Nacional de Educação para a universalização e extensão do ensino fundamental.

Em linhas gerais, quanto à educação, os anos de 1960 foram marcados pelo regime autoritário a que se submetia o País, sendo que o Executivo e os respectivos órgãos de planejamento procuravam adequar o projeto educacional - que envolvia todas as modalidades de ensino e formação profissional - ao projeto nacional da época.

Já os anos de 1980 começaram a deflagrar um movimento democrático, que culminou com a promulgação de nossa Constituição Federal de $1988^{5}$. Apesar de fornecer bastante destaque aos direitos coletivos e sociais, esta sempre foi questionada a respeito da efetiva garantia destes, uma vez que a Carta reflete contradições existentes nas constituições anteriores, onde os direitos, apesar de assegurados, não eram efetivos com relação às suas garantias.

Apesar de a educação ter sido reconhecida pela Constituição de 1988 como um direito público subjetivo ${ }^{6}$, esse reconhecimento não foi imediato, devido às inúmeras controvérsias advindas daqueles debates anteriormente apontados sobre o lugar ocupado pelo Estado e pela família na educação e seus respectivos papéis quanto à obrigatoriedade.

Se, por um lado, a garantia de determinados direitos, como o direito à educação, decorreu de pressões históricas necessárias, de outro, significou, no caso do Brasil, que a efetivação desses direitos ainda encontra-se longe de um mínimo exigível. Isso fica

5 Questões como a gratuidade do ensino e a destinação das verbas públicas foram as mais controvertidas entre grupos que participaram desse processo constituinte, e que se dividiam em opiniões.

6 E como consequência dessa condição, para que fossem protegidos contra abusos ou omissão do próprio Estado, mecanismos específicos de proteção a esses direitos foram criados e inseridos na Constituição, como por exemplo, o mandado de injunção. 
bastante evidenciado com relação ao direito de instrução primária, por exemplo, que é declarado como tal desde a Constituição de 1934, porém, a realidade prática de sua efetivação está ainda bem distante nos dias atuais.

Essa contradição existente entre a declaração do direito à educação na Constituição brasileira de 1988 e sua real efetivação é bem explicitada por Romualdo Portela de Oliveira (1995, p. 3) na seguinte passagem de sua tese de doutoramento, cujo debate ainda é bastante atual:

\begin{abstract}
Ao analisar as Constituições brasileiras no que diz respeito à declaração do Direito à Educação, concluí que a Carta Constitucional de 1988 representa um salto de qualidade relativamente à legislação anterior, deslocando o debate da efetivação deste direito, da esfera jurídica para a esfera da luta social; isto porque, através da maior precisão da redação e detalhamento de tal declaração, suprimiram-se os obstáculos legais formais à universalização do ensino fundamental para todos e em todas as idades, introduzindo-se, explicitamente, até mesmo, os instrumentos jurídicos para a sua efetivação.

Estes instrumentos ainda não foram completamente incorporados ao cotidiano de luta por educação e nem mesmo levados em conta na elaboração da política educacional. Ao contrário, têm sido, muitas vezes, desconsiderados, até mesmo, no próprio âmbito do Sistema de Justiça (Poder Judiciário, Ministério Público, Defensoria Pública).
\end{abstract}

Assim, o que houve na Constituição de 1988 foi uma tentativa de extensão do domínio privado - ainda que com modificações em relação às décadas passadas - sobre o público, conforme ressalta Maria Francisca Pinheiro (1996, p. 288) na seguinte passagem:

[...] não se trata de englobar e de ampliar interesses públicos, mas de delegar ao privado a representação do público. E, em parte, na questão das verbas e do dispositivo sobre o ensino de religião na escola pública foi essa concepção que prevaleceu na Constituição de 1988. Mais uma vez, o público foi confundido com o privado no campo do ensino. Assuntos da esfera privada, como a religião, são trazidos para a esfera pública, contrariando e negando o seu pluralismo.

Os estudos realizados pela autora pontuam as principais discussões geradas em torno da área educacional na Assembleia Nacional Constituinte de 1987 e 1988, tais como a própria Lei de Diretrizes e Bases da Educação Nacional, resultantes do conflito antigo entre o público e o privado na educação, refletindo o problema ainda maior das conflituosas relações entre Estado e sociedade no Brasil (PINHEIRO, 1996, p. 255-256).

Este conflito, traduzido na dicotomia entre o público e o privado, na área da educação, teve origem no início da década de 1930. Isto porque, naquela época, havia uma disputa pelo monopólio do ensino travada entre a escola pública e a escola privada (PINHEIRO, 1996). 
Por essa razão, a educação passou a ser um dos principais motivos de discussão no momento de formação da Assembleia Nacional Constituinte ${ }^{7}$, que definiria os pilares da nova Constituição Federal Brasileira.

O palco das discussões foram os diversos grupos que se formaram e se dividiram, de um lado, na defesa da escola pública, e de outro, na defesa do ensino privado. Os movimentos de ambos os lados se uniram para manter contatos com os parlamentares eleitos para o processo constituinte, a fim de fortalecerem suas propostas. Como resultado, tais grupos obtiveram um lugar de destaque na sociedade civil.

Para os grupos que defendiam a escola pública, dentre eles, o grupo coeso denominado "Fórum da Educação", os princípios do sistema educacional deveriam garantir a liberdade de expressão e o respeito aos direitos humanos, privilegiando-se a capacidade de reflexão crítica e de elaboração. Além disso, atribui-se ao Estado, em todos os âmbitos, a responsabilidade pelo acesso de todos e manutenção do ensino público.

Para esta manutenção e desenvolvimento da escola pública, esse grupo defendia, por exemplo, a proposta de investimento anual igual ou superior a $13 \%$ do orçamento por parte da União, e 25\%, no mínimo, da receita tributária, por conta dos Estados e Municípios.

Com relação ao ensino particular, a proposta defendida por eles dava conta de que o Estado somente poderia autorizar a sua existência, caso fossem seguidos determinados padrões de qualidade e normas relativas à educação nacional. Além disso, não haveria a benesse da isenção fiscal para as instituições privadas, devendo elas se sujeitar aos mesmos tributos incidentes sobre as atividades das demais empresas de natureza privada.

Dentre os grupos que defendiam o ensino particular, destaca-se a Fenen, ligada ao grupo leigo empresarial, cujas propostas repetem basicamente os textos constitucionais, defendendo a ideia principal de que cabe ao Estado o dever de prover o ensino público,

7 Sobre os fatos históricos que permearam a elaboração da Constituição de 1988, cita-se o seguinte trecho da obra de José Afonso da Silva, que nos permite, inclusive, diferenciar tecnicamente os termos "Assembléia Nacional Constituinte" e "Congresso Constituinte", muitas vezes utilizados pelos autores sem qualquer distinção: "Enquanto isso, o Presidente José Sarney, cumprindo mais uma etapa dos compromissos da transição, enviou ao Congresso Nacional proposta de emenda constitucional convocando a Assembléia Nacional Constituinte. Aprovada como EC n. 26 (promulgada em 27.11.85), em verdade, convocara os membros da Câmara dos Deputados e do Senado Federal para se reunirem, em Assembléia Nacional Constituinte, livre e soberana, no dia 1.2.87, na sede do Congresso Nacional. Dispôs, ainda, que seria instalada sobre a Presidência do Presidente do Supremo Tribunal Federal, que também dirigiria a sessão de eleição do seu Presidente. Finalmente, estabeleceu que a Constituição seria promulgada depois da aprovação de seu texto, em dois turnos de discussão e votação, pela maioria absoluta dos membros da Assembléia Nacional Constituinte. Assim se fez. Mas ao convocar os membros da Câmara dos Deputados e do Senado Federal, a rigor, o que se fez foi convocar, não uma Assembléia Nacional Constituinte, mas um Congresso Constituinte”. (SILVA, 2007, p. 89). 
mas também deve garantir ao aluno o ensino privado, caso seja esta a opção feita pela família.

Logo após a instalação da Constituinte em 1987, o conflito na esfera educacional foi imediatamente deflagrado, devido à participação da sociedade civil na Subcomissão de Educação, Cultura e Esportes.

O ensino, portanto, foi considerado um dos temas mais polêmicos, sendo que o debate entre o público e o privado neste campo acabou por dividir as posições no interior da Assembleia Nacional Constituinte.

A participação da sociedade civil na subcomissão teve uma influência bastante significativa nesse momento da Constituinte, que se abriu para as reivindicações da sociedade, resultando na aprovação de quase a totalidade das propostas relativas à escola pública.

Já na fase das comissões, como é o caso, por exemplo, da Comissão da Família, da Educação, Cultura e Esportes, da Ciência e Tecnologia e da Comunicação, a sociedade civil posicionou-se de uma maneira diferente em relação às subcomissões, caracterizandose não mais pelos debates, mas pela pressão exercida junto aos constituintes, na busca de votos dos parlamentares. As resoluções destas comissões temáticas - ao contrário das subcomissões, onde foram aprovadas propostas oriundas de grupos mais progressistas resultaram em um equilíbrio de forças entre grupos caracterizados como mais de esquerda e mais de direita.

No entanto, o conflito entre as posições políticas do Congresso ficou mais acirrado no momento da apresentação do primeiro projeto de Constituição, que não agradou totalmente nenhum grupo político, por se tratar de uma série de posições misturadas e contraditórias.

Naquele momento, restou clara a atuação e o poder das forças políticas que estava sendo exercido sobre o texto constitucional, que se encontrava em pleno processo de elaboração. O Poder Executivo não se satisfez com o projeto, principalmente devido às questões referentes à área trabalhista, bem como ao estabelecimento do sistema parlamentarista de governo.

Com isso, desvendou-se um cenário onde, em linhas gerais, a Comissão de Sistematização situava-se mais à esquerda dos integrantes do plenário da Constituinte, onde as posições de centro constituíam a maioria.

Formou-se também um poder paralelo ao desta comissão, devido à insatisfação de seus integrantes com o projeto da sistematização, pertencentes a setores de centro e de 
direita. Eles pretenderam ir contra o regimento interno da Constituinte, a fim de se anular as resoluções aprovadas anteriormente pelas subcomissões e comissões temáticas.

Segundo o regimento, não era possível ocorrer alterações de conteúdo nos anteprojetos aprovados, sendo somente permitido apresentar-se emendas de adequação. Assim sendo, o centro-esquerda e a esquerda apoiaram a manutenção do regimento, enquanto que o centro e a direita passaram a atacá-lo.

Dessa forma, instalou-se uma crise na Constituinte, que, apesar do atraso significativo em sua conclusão, passou a contar com um projeto de Constituição votado. Quanto à educação, não houve grandes alterações em seus dispositivos, em relação ao que havia sido aprovado anteriormente na subcomissão, exceto no que se refere ao destino dos recursos públicos, onde se estatuiu que as verbas públicas também se destinavam para as instituições comunitárias.

A aprovação do texto constitucional apontou para uma conciliação entre os diversos setores, em que embora tenha havido uma grande soma de forças desfavoráveis ao setor público, houve uma acirrada disputa de fôlego entre este e o grupo privatista, apesar de aquele necessitar ceder na maior parte das vezes. No entanto, as lutas pela escola pública não deixaram a desejar, mostrando sua força, apesar de minoritária, através da intensidade e vivacidade com que resistiram até o final do processo.

A crítica que Maria Francisca Pinheiro (1996, p. 284-288) faz em seu trabalho é de que a Constituição Federal Brasileira possui tendências conflitantes, desde a sua formação, podendo ser reforçada pelos governantes tanto pela sua face conservadora quanto pela sua face progressista. No que diz respeito à educação, tal como as constituições anteriores, apenas procurou conciliar o conflito entre o público e o privado, não o resolvendo, mas apenas absorvendo-o.

Especialmente no setor do ensino, o privado tem se destacado mais que o público no Brasil, devido ao fato de que o Estado não privilegia a sua própria atuação na esfera pública, transferindo mais recursos para a educação privada. Isso apenas confirma a tendência histórica do conflito entre o público e o privado, que não se limita à esfera da educação, mas refere-se à própria dificuldade de delimitação das esferas pública e privada da sociedade e das atribuições do Estado.

Observando-se, ainda, a seguinte passagem dos estudos realizados por Romualdo Portela de Oliveira (1995, p. 3): 
aparência, entre a necessidade - ideológica - de declará-lo e a não necessidade, do ponto de vista das relações econômicas - de efetivá-lo. Isto torna tal efetivação num elemento de disputa política. (grifo nosso)

Reforça-se, com isso, que foi adotado principalmente quanto ao direito à educação um excessivo rigor formal (técnico-jurídico) em relação ao seu reconhecimento e aplicação nos casos concretos - equivalente aos demais direitos sociais - distanciando-se da verdadeira essência da criação desse direito, qual seja, a realização de um anseio advindo da própria sociedade e respectivas lutas sociais para atender essencialmente a interesses políticos e econômicos.

\subsection{A educação como direito fundamental social na Constituição Brasileira de 1988}

Com o advento da Constituição Federal de 1988, a educação passou a ter previsão expressa no artigo $6^{\circ}$, fazendo parte do rol dos direitos fundamentais. O título que o integra é o da ordem social, onde sua regulamentação se encontra mais detalhada, dentro do capítulo III (artigos 205 a 214).

Os artigos 205 a 208 da Constituição Federal trazem a essência do direito fundamental à educação, estando definidos nesses dispositivos os seus contornos essenciais.

$\mathrm{O}$ artigo $205^{8}$, por sua vez, constitui norma de eficácia limitada, pois apenas impõe tarefas e objetivos aos órgãos públicos e também ao legislador. Já o artigo $207^{9}$ constitui norma de eficácia plena e aplicabilidade imediata, funcionando como direito fundamental de defesa.

8 Art. 205. "A educação, direito de todos e dever do Estado e da família, será promovida e incentivada com a colaboração da sociedade, visando ao pleno desenvolvimento da pessoa, seu preparo para o exercício da cidadania e sua qualificação para o trabalho". (BRASIL, 2010a).

9 Art. 207. "As universidades gozam de autonomia didático-científica, administrativa e de gestão financeira e patrimonial, e obedecerão ao princípio de indissociabilidade entre ensino, pesquisa e extensão.

$\S 1^{\circ}$ É facultado às universidades admitir professores, técnicos e cientistas estrangeiros, na forma da lei. (Incluído pela Emenda Constitucional no 11, de 1996).

$\S 2^{\circ} \mathrm{O}$ disposto neste artigo aplica-se às instituições de pesquisa científica e tecnológica. (Incluído pela Emenda Constitucional no 11, de 1996)". (BRASIL, 2010a) 
Quanto ao artigo $206^{10}$ da Constituição, este contém normas sobre princípios embasadores do ensino, possuindo uma série de dispositivos com aplicabilidade imediata e eficácia plena.

$\mathrm{O}$ artigo $208^{11}$ possui o estabelecimento de diretrizes na implementação do dever para com a educação por parte do legislador, ressaltando-se a garantia do ensino

10 Art. 206. "O ensino será ministrado com base nos seguintes princípios:

I - igualdade de condições para o acesso e permanência na escola;

II - liberdade de aprender, ensinar, pesquisar e divulgar o pensamento, a arte e o saber;

III - pluralismo de idéias e de concepções pedagógicas, e coexistência de instituições públicas e privadas de ensino;

IV - gratuidade do ensino público em estabelecimentos oficiais;

$\bigvee$ valorização dos profissionais do ensino, garantido, na forma da lei, plano de carreira para $\theta$ magistério público, com piso salarial profissionale ingresso exclusivamente por concurso público de provas e títtlos, assegurado regime jurídico único para todas as instittiçẽes mantidas pela União;

$\forall$ valorização dos profissionais do ensino, garantidos, na forma da lei, planos de carreira para $\theta$ magistério público, com piso salarial profissional e ingresso exclusivamente por concurso público de provas títtlos; (Redação dada pela Emenda Constitucional no 19, de 1998)

V - valorização dos profissionais da educação escolar, garantidos, na forma da lei, planos de carreira, com ingresso exclusivamente por concurso público de provas e títulos, aos das redes públicas; (Redação dada pela Emenda Constitucional no 53, de 2006)

VI - gestão democrática do ensino público, na forma da lei;

VII - garantia de padrão de qualidade.

VIII - piso salarial profissional nacional para os profissionais da educação escolar pública, nos termos de lei federal. (Incluído pela Emenda Constitucional nº 53, de 2006).

Parágrafo único. A lei disporá sobre as categorias de trabalhadores considerados profissionais da educação básica e sobre a fixação de prazo para a elaboração ou adequação de seus planos de carreira, no âmbito da União, dos Estados, do Distrito Federal e dos Municípios. (Incluído pela Emenda Constitucional n 53, de 2006)". (BRASIL, 2010a).

11 Art. 208. "O dever do Estado com a educação será efetivado mediante a garantia de:

I ensino fundamental, obrigatório e gratuito, inclusive para os que a ele não tiveram acesso na idade própria;

II- progressiva extensão da obrigatoriedade e gratuidade ao ensino médio;

I- ensino fundamental, obrigatório e gratuito, assegurada, inclusive, sua oferta gratuita para todos os que a ele não tiveram acesso na idade própria; (Redação dada pela Emenda Constitucional n ${ }^{\circ} 14$, de 1996)

I - educação básica obrigatória e gratuita dos 4 (quatro) aos 17 (dezessete) anos de idade, assegurada inclusive sua oferta gratuita para todos os que a ela não tiveram acesso na idade própria; (Redação dada pela Emenda Constitucional no 59, de 2009) (Vide Emenda Constitucional no 59, de 2009)

II - progressiva universalização do ensino médio gratuito; (Redação dada pela Emenda Constitucional $\mathrm{n}^{\circ}$ 14, de 1996)

III - atendimento educacional especializado aos portadores de deficiência, preferencialmente na rede regular de ensino;

IV atendimento em creche e pré-escola às crianças de zero a seis anos de idade;

IV - educação infantil, em creche e pré-escola, às crianças até 5 (cinco) anos de idade; (Redação dada pela Emenda Constitucional $\mathrm{n}^{\circ} 53$, de 2006)

V - acesso aos níveis mais elevados do ensino, da pesquisa e da criação artística, segundo a capacidade de cada um;

VI - oferta de ensino noturno regular, adequado às condições do educando;

VII - atendimento a educando, no ensino fundamental, através de programas suplementares de material didático-escolar, transporte, alimentação e assistência à sánde.

VII - atendimento ao educando, em todas as etapas da educação básica, por meio de programas suplementares de material didático escolar, transporte, alimentação e assistência à saúde. (Redação dada pela Emenda Constitucional $n^{\circ} 59$, de 2009)

$\S 1^{\circ}$ - $\mathrm{O}$ acesso ao ensino obrigatório e gratuito é direito público subjetivo.

$\S 2^{\circ}$ - O não-oferecimento do ensino obrigatório pelo Poder Público, ou sua oferta irregular, importa responsabilidade da autoridade competente. 
fundamental obrigatório e gratuito, inclusive para os que a ele não tiveram acesso em tempo oportuno, pois se trata de um direito público subjetivo.

Nesse sentido, merece destaque outro dispositivo constitucional que retrata a obrigação geral da família, da sociedade e do Estado para com a educação, qual seja, o artigo 227, caput $^{12}$.

Tamanha é a importância da educação, que o legislador tratou de, no artigo $212^{13}$ da Constituição Federal, destinar o montante da verba orçamentária mínima a ela, constituindo esta a maior parte do orçamento público.

Segundo o texto constitucional, cada um dos entes federativos deve dispor, anualmente, de um percentual mínimo da receita resultante de impostos, para a manutenção e o desenvolvimento do ensino, sendo a União responsável por dezoito por cento e os Estados, o Distrito Federal e os Municípios, vinte e cinco por cento.

Coube aos Municípios a atuação prioritária no ensino fundamental e infantil, enquanto que os Estados e o Distrito Federal foram incumbidos de priorizar a manutenção

$\S 3^{\circ}$ - Compete ao Poder Público recensear os educandos no ensino fundamental, fazer-lhes a chamada e zelar, junto aos pais ou responsáveis, pela frequiência à escola". (BRASIL, 2010a)

12 Art. 227. "É dever da família, da sociedade e do Estado assegurar à criança, ao adolescente e ao jovem, com absoluta prioridade, o direito à vida, à saúde, à alimentação, à educação, ao lazer, à profissionalização, à cultura, à dignidade, ao respeito, à liberdade e à convivência familiar e comunitária, além de colocá-los a salvo de toda forma de negligência, discriminação, exploração, violência, crueldade e opressão. (Redação dada Pela Emenda Constitucional n 65, de 2010)”. (BRASIL, 2010a)

13

Art. 212. "A União aplicará, anualmente, nunca menos de dezoito, e os Estados, o Distrito Federal e os Municípios vinte e cinco por cento, no mínimo, da receita resultante de impostos, compreendida a proveniente de transferências, na manutenção e desenvolvimento do ensino.

$\S 1^{\circ}$ - A parcela da arrecadação de impostos transferida pela União aos Estados, ao Distrito Federal e aos Municípios, ou pelos Estados aos respectivos Municípios, não é considerada, para efeito do cálculo previsto neste artigo, receita do governo que a transferir.

$\S 2^{\circ}$ - Para efeito do cumprimento do disposto no "caput" deste artigo, serão considerados os sistemas de ensino federal, estadual e municipal e os recursos aplicados na forma do art. 213.

$\S 3^{\circ}$ - A distribuição dos recursos públicos assegurará prioridade ao atendimento das necessidades do ensine obrigatório, nos termes do plano nacional de educação.

$\S 3^{\circ}$ A distribuição dos recursos públicos assegurará prioridade ao atendimento das necessidades do ensino obrigatório, no que se refere à universalização, garantia de padrão de qualidade e equidade, nos termos do plano nacional de educação. (Redação dada pela Emenda Constitucional $n^{\circ}$ 59, de 2009).

$\S 4^{\circ}$ - Os programas suplementares de alimentação e assistência à saúde previstos no art. 208, VII, serão financiados com recursos provenientes de contribuições sociais e outros recursos orçamentários.

$\S 5^{\circ}$-O ensino fundamental público terá como fonte adicional de financiamento a contribuição social do salário-educação, recolhida, na forma da lei, pelas empresas, que dela poderão deduzir a aplicação realizada no ensino fundamental de seus empregados e dependentes.

§ $5^{\circ}$ Oensino fundamental público terá como fonte adicional de financiamento a contribuição-social do salário-educação, recolhida pelas empresas, na forma da lei. (Redação-dada pela Emenda Constitucionat no 14 , de 1996)

$\S 5^{\circ}$ A educação básica pública terá como fonte adicional de financiamento a contribuição social do salário-educação, recolhida pelas empresas na forma da lei. (Redação dada pela Emenda Constitucional $\mathrm{n}^{\circ} 53$, de 2006) (Vide Decreto $\mathrm{n}^{\circ}$ 6.003, de 2006).

$\S 6^{\circ}$ As cotas estaduais e municipais da arrecadação da contribuição social do salário-educação serão distribuídas proporcionalmente ao número de alunos matriculados na educação básica nas respectivas redes públicas de ensino. (Incluído pela Emenda Constitucional n 53, de 2006)”. (BRASIL, 2010a) 
do ensino fundamental e médio. Porém, nada impede que esses entes possam atuar em outros níveis de educação, desde que sejam atendidos satisfatoriamente os objetos de suas atuações prioritárias.

Pelo fato de a Constituição Federal estabelecer, nos parágrafos $2^{\circ}$ e $3^{\circ}$ do artigo $211^{14}$, que os Estados e Municípios devem atuar com prioridade no ensino fundamental, e de igual forma os Estados, com relação ao ensino médio, e considerando o preceito instituído por ela da gratuidade do ensino fundamental público, não se mostram coerentes e admissíveis os argumentos que dizem respeito à reserva do possível e a incompetência dos tribunais para decidir sobre essa matéria. Isso porque todas as regras referentes à política de ensino como um todo já estão indubitavelmente contidas na própria Constituição.

Além disso, os direitos e garantias individuais compreendem tanto as liberdades individuais quanto o direito a prestações. Por essa razão, não se pode restringir a tutela constitucional apenas ao rol de direitos presente no artigo $5^{\circ}$, e que, por sua vez, não deve excluir outros previstos no texto constitucional, como conclusão decorrente da leitura do parágrafo segundo do artigo $5^{\mathrm{o} 15}$.

Com relação às questões da eficácia e efetividade dos direitos sociais, eis o importante posicionamento de Ingo Sarlet (2006, p. 368-370), dando conta de que ainda remanesce entre nós a forte inclinação à negação da efetividade dos direitos sociais, muito

14 Art. 211. “A União, os Estados, o Distrito Federal e os Municípios organizarão em regime de colaboração seus sistemas de ensino.

§ $1^{\circ}$ A União organizará e financiará o sistema federal de ensino e o dos Territórios, e prestará assistência técnica e financeira aos Estados, ao Distrito Federal e aos Municípios para o desenvolvimento de seus sistemas de ensino e 0 atendimento prioritário à escolaridade obrigatória.

$\S 2^{\circ}$-Os Municípios atuarão prioritariamente no ensino fundamental e pré-escolar.

$\S 1^{\circ}$ A União organizará o sistema federal de ensino e o dos Territórios, financiará as instituições de ensino públicas federais e exercerá, em matéria educacional, função redistributiva e supletiva, de forma a garantir equalização de oportunidades educacionais e padrão mínimo de qualidade do ensino mediante assistência técnica e financeira aos Estados, ao Distrito Federal e aos Municípios (Redação dada pela Emenda Constitucional no 14 , de 1996);

$\S 2^{\circ}$ Os Municípios atuarão prioritariamente no ensino fundamental e na educação infantil. (Redação dada pela Emenda Constitucional no 14, de 1996).

$\S 3^{\circ}$ Os Estados e o Distrito Federal atuarão prioritariamente no ensino fundamental e médio. (Incluído pela Emenda Constitucional no 14, de 1996).

$\S 4^{\circ} \mathrm{Na}$ organização de seus sistemas de ensino, os Estados e os Municípios definirão formas de colaboração, de modo a assegurar a universalização do ensino obrigatório. (Incluído pela Emenda Constitucional n $n^{\circ} 14$, de 1996).

$\S 4^{\circ} \mathrm{Na}$ organização de seus sistemas de ensino, a União, os Estados, o Distrito Federal e os Municípios definirão formas de colaboração, de modo a assegurar a universalização do ensino obrigatório. (Redação dada pela Emenda Constitucional no 59 , de 2009).

$\S 5^{\circ} \mathrm{A}$ educação básica pública atenderá prioritariamente ao ensino regular. (Incluído pela Emenda Constitucional $n^{\circ}$ 53, de 2006)". (BRASIL, 2010a)

15 Artigo $5^{\circ}$, parágrafo segundo: "Os direitos e garantias expressos nesta Constituição não excluem outros decorrentes do regime e dos princípios por ela adotados, ou dos tratados internacionais em que a República Federativa do Brasil seja parte”. (BRASIL, 2010a) 
mais relacionada com as fortes raízes de nosso passado cultural e histórico que propriamente advindos da intenção dos doutrinadores no momento da formulação de suas teorias, como é o caso da teoria da reserva do possível:

\begin{abstract}
Certamente não é isto que pretenderam ressaltar alguns dos nossos mais conceituados mestres, mas, sim, que existe - de modo especial entre nós - uma nítida tendência no sentido de negar-se pura e simplesmente aos direitos sociais sua eficácia e efetividade. Com efeito, pode-se chamar de ideológica a postura dos que tentam desqualificar os direitos sociais como direitos fundamentais, incluindo aqueles que outorgam às dificuldades efetivamente existentes o cunho de barreiras intransponíveis. [...] Além disso, é preciso ressaltar que ao Estado não apenas é vedada a possibilidade de tirar a vida (daí, por exemplo, a proibição da pena de morte), mas também que a ele se impõe o dever de proteger ativamente a vida humana, já que esta constitui a própria razão de ser do Estado, além de pressuposto para o exercício de qualquer direito (fundamental, ou não). Não nos parece absurda a observação de que negar ao indivíduo os recursos materiais mínimos para manutenção de sua existência (negando-lhe, por exemplo, uma pensão adequada na velhice, quando já não possui condições de prover seu sustento) pode significar, em última análise, condená-lo à morte por inanição, por falta de atendimento médico, etc. Assim, há como sustentar - na esteira da doutrina dominante - que ao menos na esfera das condições existenciais mínimas encontramos um claro limite à liberdade de conformação do legislador.
\end{abstract}

No entanto, a polêmica ainda persiste entre alguns doutrinadores e operadores do direito e o desvirtuamento da aplicação dessa e de outras doutrinas em prejuízo dos direitos fundamentais estatuídos em nossa Constituição ainda é recorrente, da mesma forma como também é constante o desrespeito aos direitos humanos de um modo geral.

E mais especificamente quanto ao direito à educação, mas ainda nesse sentido, prossegue afirmando com propriedade Sarlet (2006, p. 370):

\begin{abstract}
[...] neste sentido, não restam dúvidas de que manter o indivíduo sob o véu da ignorância absoluta significa tolher a sua própria capacidade de compreensão do mundo e sua liberdade (real) de autodeterminação e de formatar sua existência. O princípio da dignidade da pessoa humana pode vir a assumir, portanto, importante função demarcatória, estabelecendo a fronteira para o que se convenciona denominar de padrão mínimo na esfera dos direitos sociais. A idéia subjacente ao modelo de Canotilho e dos autores germânicos referidos parece ser precisamente esta: onde faltam as condições materiais mínimas, o próprio exercício da liberdade fica comprometido, e mesmo os direitos de defesa não passam de fórmulas vazias de sentido.
\end{abstract}

Assim sendo, diante dos conflitos de direitos e de soluções jurídicas que estão postos, a melhor doutrina entende que uma possível solução esteja calcada nas circunstâncias do caso concreto, privilegiando-se o princípio da proporcionalidade ${ }^{16}$, uma vez que não se mostra

16 André de Carvalho Ramos (2005, p. 136-137), ao tratar dos limites dos direitos humanos na ordem internacional, traz também uma abordagem elementar sobre este princípio: "o princípio da proporcionalidade consiste na aferição da idoneidade, necessidade e equilíbrio da intervenção estatal em determinado direito fundamental. Origina-se da lógica da moderação e justiça que deve incidir sobre toda intervenção estatal sobre 
possível o estabelecimento de uma única direção de critérios para ponderar os direitos e valores em conflito.

Os próprios princípios existentes na Constituição dão conta de que a administração pública deve atuar com moralidade e eficiência, principalmente quando se deve administrar a escassez de recursos e fazer com que os direitos sociais se tornem efetivos. Os órgãos estatais e agentes políticos devem se responsabilizar de maximizar os recursos e minimizar o impacto da reserva do possível, sem que esta última seja utilizada como entrave para a intervenção judicial e omissão estatal no campo da efetivação dos direitos fundamentais como um todo, principalmente os direitos sociais.

\subsection{O direito à educação e os princípios constitucionais}

Além disso, os direitos sociais são consagrados no preâmbulo da Constituição Brasileira e possuem características que os unem diretamente ao princípio da dignidade da pessoa humana.

O fato do direito à educação estar diretamente ligado aos princípios fundamentais da República Federativa do Brasil, em especial ao da dignidade da pessoa humana, advém tanto da herança do texto constitucional quanto das diversas convenções internacionais que tratam dessa matéria.

A efetividade do direito à educação está intimamente ligada à própria garantia do direito à livre determinação. A educação, portanto, classificada como um direito social é indispensável à efetivação do direito à liberdade, que até mesmo o antecede na formação do Estado de Direito.

direitos dos indivíduos, mesmo que o fim do ato restritivo seja evitar dano a outro direito individual. É uma técnica de controle do poder estatal (ou como querem alguns doutrinadores, é o limite dos limites dos direitos fundamentais), mas também é um controle indireto do conteúdo do próprio direito fundamental analisado.

A doutrina e a jurisprudência habitualmente decompõem o princípio da proporcionalidade em três elementos, a saber: a adequação das medidas estatais à realização dos fins propostos, a necessidade de tais medidas e finalmente a ponderação (ou equilíbrio) entre a finalidade perseguida e os meios adotados para sua consecução (proporcionalidade em sentido estrito).

Tal detalhamento do princípio da proporcionalidade garante transparência e coerência no controle dos atos estatais, que são efetuados em geral pelos Tribunais. Assim busca-se evitar o decisionismo ou arbítrio judicial. Esse receio de um novo arbítrio, agora judicial (em geral de um tribunal superior ou de uma Corte Constitucional, mas também de um tribunal internacional), é explicado porque o juízo de proporcionalidade avalia o próprio conteúdo do ato estatal, quer seja o conteúdo de uma lei, de uma decisão administrativa ou de uma decisão judicial". 
A Constituição Federal tratou também de regular a competência legislativa entre os entes da Federação, sendo certo de que não existe hierarquia entre as normas advindas dos diferentes entes federativos. O que existe entre eles representa apenas uma divisão de competências, em que à União compete legislar, de forma privativa, sobre diretrizes e bases da educação nacional (artigo 22, XXIV, CF/88) ${ }^{17}$, e de forma concorrente com os Estados e o Distrito Federal, compete-lhe legislar sobre educação, cultura, ensino e desporto (artigo 24, IX, CF/88) ${ }^{18}$. Os Estados podem, ainda, dispor sobre a matéria em suas respectivas Constituições, devendo estar em consonância com os princípios constantes da Constituição da República.

Havendo conflitos entre os direitos, portanto, um deles deve ceder em prol do outro, ou ambos devem fazer concessões mútuas até que seja encontrada a situação mais justa e condizente com o ordenamento jurídico no caso concreto. Essa ponderação deve se utilizar de critérios racionais, a fim de se identificar qual princípio possui o maior peso em determinada situação e se evitar subjetivismos.

Quanto às normas constitucionais relativas à educação fundamental, estas asseguram o imediato gozo desse direito, pois o próprio artigo $208, \S 1^{\circ}$ da Constituição ${ }^{19}$ trata-o como direito subjetivo público, com eficácia plena e aplicabilidade imediata. Além disso, integram o rol mínimo de direitos indispensáveis a uma existência digna, excluída qualquer hipótese de sua não efetivação.

De acordo com a doutrina, o denominado mínimo existencial corresponde ao núcleo comum dos direitos fundamentais, indicando o conteúdo intransponível desses direitos. Esse conteúdo mínimo dos direitos fundamentais possui característica de universalidade, e resulta de sua incorporação aos tratados internacionais, às cartas políticas e à legislação infraconstitucional, tornando obrigatória a sua interpretação, dado os valores maiores aí envolvidos.

Desse modo, a obediência a esse conteúdo mínimo se faz devido ao cumprimento da própria Constituição, não sendo permitido ao Estado adotar quaisquer medidas que frustrem a sua aplicação.

17 Art. 22. "Compete privativamente à União legislar sobre: [...] XXIV - diretrizes e bases da educação nacional”. (BRASIL, 2010a).

18 Art. 24. "Compete à União, aos Estados e ao Distrito Federal legislar concorrentemente sobre: (...)IX educação, cultura, ensino e desporto". (BRASIL, 2010a).

19 Art. 208. "O dever do Estado com a educação será efetivado mediante a garantia de: [...] $§ 1^{\circ}$ - O acesso ao ensino obrigatório e gratuito é direito público subjetivo”. (BRASIL, 2010a). 
Disso deflui a conclusão de que o direito à educação impõe ao Estado a sua prestação, implicando na observância necessária dos princípios contidos na atividade estatal. Constitui serviço público essencial, sendo obrigatória a sua manutenção de forma regular e contínua, nunca abaixo das exigências a serem necessariamente cumpridas.

Assim, caso haja descumprimento desse dever jurídico relativo ao direito à educação, deve-se fazer uso dos instrumentos processuais contidos no texto constitucional, tais como o mandado de segurança, o mandado de injunção e a ação civil pública. Devido ao caráter da educação como direito público subjetivo no acesso ao ensino obrigatório e gratuito, seu não oferecimento ou sua oferta irregular importa responsabilidade da autoridade competente.

A partir disso, torna-se inaceitável o simples argumento de que não existem recursos para atender à demanda desses direitos, pois, para tanto, seria necessária a prova plena e cabal dessa situação por parte do Poder Público. Caso provada a inexistência total de recursos, ainda assim, é totalmente viável a emissão de provimento jurisdicional com a finalidade de determinar a realocação de recursos orçamentários para atender os direitos prestacionais, como é o caso do direito à educação fundamental, por constituir valor atrelado à dignidade da pessoa humana. 


\section{A EDUCAÇÃO DENTRE OS DIREITOS HUMANOS: COMPETÊNCIAS E ATRIBUIÇÕES}

A igualdade de todos constitui um dos primados básicos da democracia, sendo que esta deve ser entendida como igualdade de oportunidades, para que efetivamente sejam atingidos os ideais de justiça social.

É nesse contexto que se insere a educação, ou seja, como caminho obrigatório para garantir a igualdade de oportunidades, através do desenvolvimento pleno da pessoa, sua aptidão para o trabalho e para o exercício da cidadania.

Ricardo Lobo Torres (2003, p. 37-38), em seu artigo intitulado A metamorfose dos direitos sociais em mínimo existencial, considera que

[...] a igualdade de chances ou de oportunidades, que é igualdade na liberdade, informa a idéia de mínimo existencial, que visa a garantir as condições iniciais da liberdade. Pela igualdade de chances garantem-se as condições mínimas para o florescimento da igualdade social, que pode se compaginar até com uma certa desigualdade final provocada pelo esforço de cada um. No Canadá, o art. 36 da Constituição estabelece que o Parlamento deverá adotar medidas para "a) promover a igualdade de chances (equal opportunities, égalité des chances) de todos os canadenses na procura do seu bem-estar; b) favorecer o desenvolvimento econômico para reduzir a desigualdade de chances".

A igualdade de resultados compõe a idéia de justiça. A sua obtenção depende do nível de riqueza do país e da reserva da lei. Dworkin, em obra recente, distingue entre igualdade de bem-estar (equality of welfare) e igualdade de recursos (equality of resources); a igualdade de bem-estar se aproxima da idéia de igualdade de resultados, pois se caracteriza quando o esquema distributivo já não possa deixar as pessoas "mais iguais em bem-estar" (more equal in welfare). Na França, Rosanvallon defende a possibilidade de se transformar a égalité des chances em uma equité des chances, entendida como direito igual a tratamento equivalente. A eqüidade de chances não consiste somente em compensar as desigualdades da natureza ou as disparidades da fortuna; visa a reordenar os instrumentos necessários à existência; seu objetivo é dar aos indivíduos os meios da (sic) fazer face às áleas que não são de ordem classicamente securitária (acontecimentos familiares, problemas pessoais, rupturas profissionais repetidas, etc.).

Para Romualdo Portela de Oliveira (1995, p. 59), “[...] a educação, independentemente de seu conteúdo curricular e da introdução desta ou daquela disciplina, é um elemento constitutivo da cidadania".

O conceito de cidadania envolve a própria capacidade do homem compreender e estar a par - e, assim, participar e propor mudanças - dos problemas políticos, sociais, econômicos, ambientais e culturais tanto de sua comunidade local como do país como um todo. 
Por essa razão, percebe-se que a educação possui um caráter político, devendo-se dar a ela a máxima prioridade, com vistas ao próprio aprimoramento das instituições e o aperfeiçoamento do regime democrático.

Por democracia deve-se entender um regime em que a participação do cidadão se dá a partir do seu direito à escolha dos representantes - a questão do voto -, mas acima de tudo os debates sobre como viveremos juntos, com nossos valores de liberdade e igualdade e nosso conjunto de direitos. O direito à cidadania, por seu turno, engloba o direito de votar e ser votado, de participar de processos eleitorais, e principalmente o real e concreto exercício da liberdade, assim entendido como a participação ativa perante a sociedade com poder de influência e decisão.

Dessa forma, o papel da educação revela sua fundamental importância para o exercício da cidadania, por conta de cumprir com a formação necessária para que essa participação possa, de fato, acontecer, dentro dos princípios do respeito à dignidade e igualdade do outro.

Com o levantamento das normas nacionais e internacionais que garantem o direito à educação escolar, veremos, a seguir, que apenas é suprida a questão da igualdade formal de todos no que diz respeito à abrangência deste direito. Além disso, constata-se que as políticas públicas, que deveriam ser efetivamente garantidoras da concretização do direito à educação, ainda se mostram insuficientes para atingir a igualdade material de todos em relação a este direito.

Essa situação objetivará a constatação da violação de uma das principais características definidoras da própria natureza dos direitos humanos, qual seja, o seu caráter de universalidade ${ }^{20}$.

\subsection{O processo de internacionalização dos direitos humanos}

O processo de internacionalização dos direitos humanos despontou no período do Pós-Guerra, como reação à barbárie instituída pelo nazismo, que utilizava o extermínio em massa de seres humanos como pretexto à purificação da raça.

20 A doutrina considera a universalidade, a indivisibilidade e a interdependência entre si como sendo as características definidoras dos direitos humanos. Estes direitos, por sua vez, devem estar sempre em consonância com o princípio constitucional da dignidade da pessoa humana. 
Para que se viabilizasse um projeto de reconstrução dos direitos humanos no PósGuerra, surgiu na esfera do Direito Internacional um sistema normativo internacional de proteção dos direitos humanos, voltado a garantir os direitos fundamentais e a limitar o poder do Estado (PIOVESAN, 2010).

Os primeiros pilares desse processo de internacionalização dos direitos humanos foram o Direito Internacional Humanitário, a Liga das Nações e a Organização Internacional do Trabalho.

O primeiro deles se destinava a impor limites jurídicos ao emprego da violência no âmbito internacional, em casos de guerra.

Já a Liga das Nações possuía o escopo de obter a paz, segurança e cooperação internacional, através da eliminação de toda e qualquer ameaça à integridade territorial e à independência política de seus membros.

Por sua vez, a Organização Internacional do Trabalho primava por condições de trabalho justas e dignas, impondo determinados padrões internacionais a serem seguidos.

Com o advento da Declaração de 1948, os direitos humanos foram caracterizados pela sua universalidade e indivisibilidade, interligando os direitos civis e políticos aos direitos econômicos, sociais e culturais. Nesse contexto, ainda, surgem os inúmeros instrumentos internacionais de proteção, que passam a constituir o Direito Internacional dos Direitos Humanos.

Esse sistema internacional de direitos humanos é formado por diversos tratados internacionais, onde existem padrões mínimos de proteção aos direitos humanos, denominado "mínimo ético irredutível”. Além desse sistema global, surgem os sistemas regionais de proteção, cujo objetivo principal é o de promover a internacionalização dos direitos humanos nas esferas regionais, englobando principalmente a Europa, a América e a África.

Tendo como base os princípios contidos na Declaração Universal, os sistemas global e regional são complementares, constituindo um conjunto de instrumentos de proteção dos direitos humanos no campo internacional.

Dentre esses instrumentos, destaca-se a Declaração e Programa de Ação de Viena, de 1993, que veio reafirmar a concepção da Declaração de 1948, consolidando a interrelação existente entre os preceitos dos direitos humanos, democracia e desenvolvimento.

Além disso, a criação da ONU e suas respectivas agências especializadas e o Tribunal de Nuremberg nos anos de 1945-1946 tiveram papel imprescindível na reconstrução dos direitos humanos após a $2^{\mathrm{a}}$ Guerra Mundial, com a cooperação dos 
Estados no campo civil, econômico, social e cultural, incluindo a padronização da saúde e da proteção ao meio ambiente na esfera internacional.

Assim sendo, a ONU passa a tratar de assuntos que interessam a todos os países, tornando-se o organismo responsável pelo desenvolvimento do processo de internacionalização dos direitos humanos, pois começa a tratar de temas antes restritos à esfera interna de cada nação.

Com isso, houve a emergência do valor da dignidade humana como referencial ético de orientação do constitucionalismo contemporâneo, tanto do ponto de vista local, como também regional e global. A proteção dos direitos humanos passou a despertar interesse na órbita internacional e, com isso, de acordo com Flávia Piovesan (2010, p. 120$121)$,

\footnotetext{
[...] prenuncia-se o fim da era em que a forma pela qual o Estado tratava seus nacionais era concebida como um problema de jurisdição doméstica, restrito ao domínio reservado do Estado, decorrência de sua soberania, autonomia e liberdade. Aos poucos, emerge a idéia de que o indivíduo é não apenas objeto, mas também sujeito de Direito Internacional. A partir dessa perspectiva, começa a se consolidar a capacidade processual internacional dos indivíduos, bem como a concepção de que os direitos humanos não mais se limitam à exclusiva jurisdição doméstica, mas constituem matéria de legítimo interesse internacional.
}

No entanto, esse processo de internacionalização dos direitos humanos - carregado de tensões e conflitos, como, por exemplo, entre seu universalismo suposto e os particularismos culturais - é um dos campos de luta na atualidade, pois as violações de direitos humanos acontecem, de formas diversas, nos mais variados países.

É sabido que, dentre as inúmeras atribuições pertinentes ao Estado, está a de promover medidas que atendam aos direitos humanos. No ordenamento jurídico brasileiro, a proteção desses direitos se dá através das três esferas de poder, sendo que ao Judiciário cumpre a tarefa de garantir a efetividade do cumprimento das normas, contribuindo todos eles para a efetivação das obrigações internacionais assumidas pelo país.

\subsection{O papel do Judiciário: o caso do STF}

Dentro dessa perspectiva, entende-se que apenas uma atuação concatenada entre elas pode garantir a efetiva aplicação dos direitos humanos. No Brasil, o Supremo Tribunal Federal possui o fundamental papel de guardião da Constituição Federal, a partir da 
garantia dos direitos individuais, de um lado, e a efetivação de políticas públicas, de outro lado, a permitir a realização da igualdade e a verdadeira efetividade dos direitos humanos. (AMARAL JÚNIOR; JUBILUT, 2009).

Porém, o Judiciário, de uma forma geral, continua priorizando, em sua atuação, a efetivação dos direitos civis e políticos, cuja titularidade é individual. Com isso, tal postura se reflete reiteradamente junto ao Supremo Tribunal Federal, que adequou sua jurisprudência ao Direito Internacional dos Direitos Humanos procurando atender os direitos humanos mais tradicionais, como, por exemplo, aqueles que dizem respeito à liberdade de expressão, associação e reunião e a proibição à tortura.

Contudo, resta ainda avançar no que tange aos direitos sociais e de titularidade coletiva, pois a Suprema Corte continua adotando uma posição demasiadamente conservadora, em que apenas se reconhece a existência do direito, mas não se dá efetividade aos tratados internacionais vigentes no País.

É por essa razão que os denominados direitos sociais, tais como o direito ao trabalho, à saúde e à educação são extremamente carentes de medidas de efetivação no campo do Direito Internacional dos Direitos Humanos, com o objetivo de se dar soluções adequadas e eficazes para as inúmeras questões coletivas que são suscitadas.

Dentro desse contexto, para Amaral Junior e Jubilut (2009, p. 44-45),

\footnotetext{
[...] ao adotar esta postura, verifica-se que o STF se furta a efetivar um "direito a políticas públicas" e a auxiliar a construção de uma ordem social em que o direito ao desenvolvimento (também um direito humano em si) possa ser efetivado.

Tal postura do STF parece ter como uma de suas bases uma forte preocupação em resguardar a separação de poderes e as competências exclusivas de cada esfera de poder, o que se coaduna com a ideia central, também presente nos direitos humanos, de limitar o poder. Contudo, a plena realização dos direitos humanos, como mencionado, depende da atuação combinada das três esferas de poder, e o STF, como ápice do Poder Judiciário, não pode deixar de atuar na busca da efetivação dos direitos humanos, sobretudo quando outras instâncias já incorreram em omissão.

Assim, constata-se que há espaço para uma atuação mais incisiva do STF, no que tange aos direitos de cunho social e coletivo, sem que haja violação da teoria tradicional de separação de poderes, até porque ao agir em prol dos direitos humanos o STF estará visando à própria finalidade a que serve tal teoria: limitar o poder e garantir a proteção completa do indivíduo.
}

A análise da própria jurisprudência do STF aponta para o fato de que os instrumentos processuais mais antigos, como o habeas corpus, são os mais utilizados com o objetivo de se obter reparação à violação de direitos humanos. Porém, o excesso de preocupação da Suprema Corte com a adequação formal do instrumento processual ao caso concreto, constitui outro óbice à efetividade dos direitos humanos. 
Por outro lado, tem-se que o STF somente passou a referir-se aos tratados internacionais a partir de 1988, mas sempre de forma a privilegiar a normativa interna, em detrimento da aplicação concreta do Direito Internacional dos Direitos Humanos, que ocorre apenas de forma incidental e indireta, tendo como exemplos mais típicos as questões de direito ambiental.

Nota-se que há uma grande contradição entre as decisões do STF e o que pugna o Direito Internacional dos Direitos Humanos, o que pode implicar uma responsabilização internacional do Brasil cada vez maior, como de fato já vem ocorrendo, devido ao aumento do número de casos contra o Brasil perante o Sistema Interamericano de Direitos Humanos.

Dentro desse universo de contradições vividas pelo STF, Amaral Junior e Jubilut (2009, p. 48) destacam o seguinte:

[...] a aplicação do Direito Internacional dos Direitos Humanos pelo STF parece ocorrer de forma adequada quando o tema é essencialmente tratado pelo Direito Internacional (como, por exemplo, o genocídio), mas quando se trata de tema já trabalhado pelo sistema interno a prática do STF parece minimizar as normas internacionais e, com isso, afastar a proteção mais completa que se poderia garantir à pessoa humana.

Ademais, constata-se que outra dificuldade de implementação de tratamento adequado ao tema se deve ao fato de que não existe um consenso acerca do significado de dignidade humana, tornando-se muito amplo este conceito ao ser analisado pelas decisões do STF. Isso retrata um panorama geral do Judiciário em nosso país, que parece sempre possuir dificuldade de adequação e enquadramento de medidas ao caso concreto, quando não existe positivação de determinado elemento dentro de nosso ordenamento.

Segundo a pesquisa realizada por Amaral Junior e Jubilut (2009, p. 48-49):

[...] não há na jurisprudência de nossa mais alta Corte um condensamento da teoria de direitos humanos, fato que dificulta não somente a aplicação das normas sobre o tema, mas que diminui a proteção à dignidade da pessoa humana ao não incorporar de forma sistemática a contribuição do Direito Internacional dos Direitos Humanos.

Nesse sentido, o STF minimiza seu papel de auxiliar na construção de uma ordem social que privilegie os direitos humanos e assegure o "Estado Democrático de Direito" no Brasil. Este papel vai além da decisão de casos particulares, mas passa pela alteração de toda uma cultura (jurídica e social); alteração esta que está na base do estabelecimento tanto da ética de meios quanto do respeito à dignidade humana propugnados pelo Direito Internacional dos Direitos Humanos.

Ocorre que, apesar dos direitos humanos não serem preocupação e atuação exclusiva dos Estados, é imprescindível que este adote políticas públicas adequadas a esse 
respeito em seu âmbito interno. Isso porque a própria adoção dessas políticas internas contribui para uma maior obediência aos direitos humanos no cenário internacional, buscando a solução de problemas de determinados grupos mais vulneráveis ao ataque desses direitos.

Por esses motivos é que surgiram as jurisdições internacionais, tais como o Sistema Global e os Sistemas Regionais, ambos com o propósito de padronizar a proteção aos direitos humanos, ressaltando a atuação dos Estados com relação às ordens jurídicas pertinentes a essa matéria.

Dentro desse contexto, tem-se que o dever de adotar medidas de direito interno encontra-se explícito nas Convenções que tratam da atuação nos Sistemas Regionais. A título de ilustração, serão citados apenas alguns dispositivos contidos no Sistema Interamericano, tais como os artigos $1^{\circ}$ e $2^{\circ}$ da Convenção Americana de Direitos Humanos (Pacto de San José da Costa Rica), que dispõem o seguinte:

Artigo $1^{\circ}$. Obrigação de respeitar os direitos.

1. Os Estados-partes nesta Convenção comprometem-se a respeitar os direitos e liberdades nela reconhecidos e a garantir seu livre e pleno exercício a toda pessoa que esteja sujeita à sua jurisdição, sem discriminação alguma, por motivo de raça, cor, sexo, idioma, religião, opiniões políticas ou de qualquer outra natureza, origem nacional ou social, posição econômica, nascimento ou qualquer outra condição social.

2. Para efeitos desta Convenção, pessoa é todo ser humano.

Artigo $2^{\circ}$. Dever de adotar disposições de direito interno.

Se o exercício dos direitos e liberdades mencionados no artigo $1^{\circ}$ ainda não estiver garantido por disposições legislativas ou de outra natureza, os Estadospartes comprometem-se a adotar, de acordo com as suas normas constitucionais e com as disposições desta Convenção, as medidas legislativas ou de outra natureza que forem necessárias para tornar efetivos tais direitos e liberdades. (VIEIRA, 2001, p. 256).

Nessa mesma esteira de proteção, existe o Protocolo de San Salvador, que possui caráter complementar à Convenção Americana de Direitos Humanos, e dispõe em seus artigos $1^{\circ}$ e $2^{\circ}$ acerca do dever do Estado de adotar medidas em seu direito interno, porém, neste caso, especialmente no que se refere aos direitos econômicos, sociais e culturais.

Da mesma forma, já houve o pronunciamento da Corte Interamericana de Direitos Humanos em opiniões consultivas - como é o caso da OC-11/90, de 10.08.1990 - acerca desse dever dos Estados em adotarem medidas internas, visando atender aos direitos estatuídos na Convenção Americana.

Portanto, é necessário que não haja qualquer tipo de separação entre as esferas nacional e internacional, ressaltando-se sempre o caráter de complementaridade entre ambas. Nos dizeres de Adriana Estigara (2007, p. 452), 
[...] o que se quer é a compatibilização dessas esferas e para isso inúmeros são os instrumentos à disposição, a exemplo das cláusulas facultativas para o reconhecimento da competência dos órgãos de supervisão internacional para examinar petições ou comunicações individuais ou interestatais; para o reconhecimento da jurisdição compulsória dos órgãos judiciais de proteção dos direitos humanos; cláusulas de reservas, derrogações e limitações permissíveis, dentre outros.

Assim sendo, aquelas decisões que apenas levam em conta uma situação individual acerca de um direito fundamental envolvido, sem considerar a complexidade dela diante da realidade, constituem verdadeiros óbices à efetivação dos direitos humanos fundamentais (VEÇOSO, 2009, p. 93).

Cabe ao Poder Judiciário, em especial ao Supremo Tribunal Federal, a missão de assegurar de modo efetivo os pactos sociais e políticos onde estão contidos os direitos humanos. Mesmo sabendo que este Poder, por si só, não se mostra suficiente para a realização de todos esses direitos - uma vez que a atuação conjunta dos três Poderes é imprescindível nesse propósito -, o seu papel de guardião da Constituição Federal é fundamental para a efetivação do Estado Democrático de Direito.

No que tange à proteção jurídica internacional, o Brasil está diretamente relacionado ao Sistema Interamericano de Direitos Humanos, onde se opera a responsabilização internacional do Estado perante as violações aos direitos humanos.

Para situá-lo na história, esse sistema surgiu com o advento da Convenção Americana de Direitos Humanos, em 1969, também conhecido como Pacto de San José da Costa Rica, diante do panorama da Organização dos Estados Americanos (OEA), cuja criação se deu em 1948.

O objetivo da criação da Convenção foi o de criar obrigação jurídica para os países, de acordo com o que foi instituído pela Corte Interamericana de Direitos Humanos. Além disso, a Comissão Interamericana foi instituída em 1959, cuja finalidade de seus órgãos é a de proporcionar o funcionamento do Sistema.

Cita-se também outros instrumentos, de natureza declarativa, que executam a função de orientação do Sistema Interamericano, quais sejam, a Declaração Americana dos Direitos e Deveres dos Homens e o Protocolo de San Salvador.

A Convenção Americana significou uma grande evolução normativa, cuja importante expressão se deu na Declaração Americana de Direitos e Deveres do Homem, representando a parte normativa do Sistema Interamericano. 
O principal objetivo da Comissão é proporcionar a caracterização e a defesa dos direitos humanos inseridos na Convenção Americana sobre Direitos Humanos, relativos aos seus Estados-partes, bem como aqueles estatuídos na Declaração Americana de Direitos e Deveres dos Homens relativos aos outros Estados-membros, funcionando como órgão de caráter consultivo da Organização com relação a esse assunto ${ }^{21}$. Já a Corte Interamericana de Direitos Humanos possui atuação de natureza jurisdicional ou contenciosa e consultiva.

Seguindo esse raciocínio, Adriana Estigara (2007, p. 460-61) afirma que

[...] o desempenho da função jurisdicional pode ser provocado pela Comissão, quando, a despeito de ter aguardado o prazo concedido para o Estado tomar as providências recomendadas no relatório, este não as observou, desde, é claro, que o Estado denunciado tenha reconhecido a jurisdição compulsória da Corte, ou por iniciativa do Estado interessado que seja Parte da Convenção e que tenha aceito a sua competência obrigatória.

A competência consultiva alude à interpretação e à aplicação da Convenção Americana sobre Direitos Humanos, das disposições de tratados concernentes à proteção dos direitos humanos nos Estados americanos, bem como da compatibilidade da legislação e políticas públicas dos países, não reclamando convenção especial, e o exercício da mesma pode ser provocado por qualquer membro da OEA, seja ou não, parte da Convenção.

A competência contenciosa abarca denúncias de violações dos direitos consagrados na Convenção e é reservada aos Estados-Partes da Convenção que tenham reconhecido a jurisdição da Corte.

Uma vez advinda ao Estado uma condenação no âmbito internacional, resta a ele cumprir a decisão da Corte que lhe foi imposta, seguindo o seu procedimento interno de execução de sentenças. Nesse sentido, não é permitido ao Estado alegar motivo de impedimento sob o pretexto de seu direito interno, pois fica comprometido em proteger os direitos humanos.

21 Como informa Adriana Estigara (2007, p. 459): “entre as funções da Comissão Interamericana, destacam-se a 'promotora' e a 'protetora'. No âmbito daquela, verifica-se algumas formas através das quais o Sistema pode atuar fomentando políticas públicas de direitos humanos nos Estados americanos. Entre elas, encontram-se: a) fazer recomendações aos governos dos Estados-Membros prevendo a adoção de medidas adequadas à proteção destes direitos; b) preparar estudos e relatórios que se mostrem necessários; c) requisitar aos Governos informações relativas às medidas por eles adotadas concernentes à efetiva aplicação da Convenção; d) submeter um relatório anual à Assembléia Geral da $O E A$.

No desempenho da função protetora, a Comissão encarrega-se de examinar as petições encaminhadas por indivíduo, grupos de indivíduos ou entidades não-governamentais, que denotem violação aos direitos consagrados na Convenção Americana. Esta função é reconhecida pelos Estados tão logo se tornem partes da Convenção. Eles aceitam automática e obrigatoriamente a competência da Comissão para examinar petições individuais, não sendo necessária a elaboração de qualquer declaração expressa e específica para este fim" (grifo nosso). 
De acordo com os artigos 67 e 68 da Convenção Americana sobre Direitos Humanos $^{22}$, a Corte Interamericana possui a tarefa jurisdicional de promover um controle sobre o cumprimento de suas próprias sentenças, enquanto que a Comissão não possui esse mesmo mecanismo de controle sobre suas recomendações.

Assim sendo, caso o Estado descumpra uma decisão da Corte Interamericana, farse-á uma comunicação à Assembleia Geral da OEA, podendo gerar punições de caráter econômico.

Com isso, tem-se que o Sistema Interamericano acaba por pressionar os Estados a promoverem políticas públicas de direitos humanos, mesmo no âmbito da Comissão. Já no que diz respeito à decisão da Corte, esta possui grande força nesse sentido, pois caso não sejam cumpridas suas recomendações, poderão acarretar punições na esfera econômica, bem como reflexos negativos para o Estado violador do ponto de vista político, perante toda a ordem internacional ${ }^{23}$.

\subsection{O papel da sociedade civil}

Atualmente, porém, não se pode atribuir a responsabilidade exclusiva ao Estado na proteção dos direitos humanos, uma vez que para satisfazê-los plenamente, deve-se passar necessariamente pela implementação de políticas públicas, a serem efetivadas não somente através de ações do Estado, mas também de ações advindas pelo esforço conjunto de diversos segmentos da sociedade.

22 Artigo 67 - "A sentença da Corte será definitiva e inapelável. Em caso de divergência sobre o sentido ou alcance da sentença, a Corte interpretá-la-á, a pedido de qualquer das partes, desde que o pedido seja apresentado dentro de noventa dias a partir da data da notificação da sentença".

Artigo 68 - 1. "Os Estados-partes na Convenção comprometem-se a cumprir a decisão da Corte em todo caso em que forem partes.

2. A parte da sentença que determinar indenização compensatória poderá ser executada no país respectivo pelo processo interno vigente para a execução de sentenças contra o Estado". (ORGANIZAÇÃO DOS ESTADOS AMERICANOS, 1969).

23 “A adesão do Brasil à jurisdição obrigatória de órgãos estruturados especificamente por meio de tratados para a apuração transparente e técnica de violação de direitos humanos é vantajosa tanto ao indivíduo quanto ao próprio Estado brasileiro. [...] Com o reconhecimento brasileiro da jurisdição obrigatória da Corte beneficiou-se o indivíduo, que agora tem direito à proteção judicial internacional; beneficiou-se o Estado brasileiro, que pode repelir a aplicação de sanções unilaterais e beneficiou-se a sociedade internacional como um todo, por ser a proteção dos direitos humanos um importante passo rumo ao estabelecimento de uma sociedade justa e igual entre todos os povos da Terra". (RAMOS, 2001, p. 517$18]$. 
No Brasil, dentre as iniciativas existentes para a efetivação desses direitos, cita-se a atuação das organizações do terceiro setor, que passaram a exercer uma advocacia específica para o Direito Internacional dos Direitos Humanos.

Contextualizando nosso País em relação aos litígios internacionais em que se encontra envolvido, tem-se que, conforme noticiado pela imprensa nacional de 17 de agosto de 2011, "aumenta o número de denúncias contra o Brasil nos órgãos da OEA”. Tal notícia também nos dá conta de que:

[...] nos últimos dez anos, o Brasil foi objeto de 507 denúncias de violação do chamado "Pacto San José", firmado em 1969 e ratificado pelo País em 1992. Desse total, 29 denúncias foram acolhidas para análise pela Comissão. Só em um desses casos o Brasil sofreu nove medidas cautelares, uma das quais resultou no fechamento, em 2007, da unidade que a antiga Febem mantinha no bairro do Tatuapé. As demais exigiam providências imediatas para o descongestionamento do sistema prisional [...] O balanço da Comissão também revela que o número de denúncias apresentadas contra o Brasil nos órgãos da OEA vem aumentando significativamente. Hoje, há 108 petições protocoladas por casos de assassinato, prisões degradantes e crimes contra a infância e a adolescência. (O BRASIL..., 2009).

Para melhor compreensão desse fenômeno, cumpre observar que houve mudança no perfil dos proponentes dessas ações internacionais submetidas à Comissão Interamericana de Direitos Humanos, em decorrência do próprio momento histórico vivido por eles:

[...] considerando a demarcação dos dois distintos períodos, observa-se que durante o regime militar, de 1964 a 1985, 90\% das comunicações examinadas foram encaminhadas por indivíduo ou grupo de indivíduos - em apenas um único caso a comunicação foi encaminhada por entidades não governamentais. Já no segundo período, relativo ao processo de democratização, $100 \%$ dos casos examinados foram encaminhados por entidades não governamentais de defesa dos direitos humanos, de âmbito nacional ou internacional, e, por vezes, pela atuação conjunta dessas entidades. (PIOVESAN, 2010, p. 343).

Percebe-se, através da leitura desses dados, que, na medida em que houve uma libertação do regime ditatorial, houve também um fortalecimento da sociedade civil, podendo-se falar em um movimento que culminou num processo de democratização.

Dentro desse processo de democratização, as organizações não governamentais ocuparam posição de destaque ${ }^{24}$, contribuindo para o fortalecimento da proteção dos

24 Sobre a importância da atuação das organizações não governamentais na proteção internacional dos direitos humanos, cita-se importante estudo realizado por Marina Feferbaum (2012, p. 112-113), referente ao sistema africano: "Outro fator que poderá comprometer a efetividade jurídica do sistema regional africano é a dificuldade de acesso à tutela do Tribunal. Restrito aos Estados envolvidos e organizações intergovernamentais, o acesso à jurisdição do Tribunal Africano tem motivação 
direitos humanos, em nosso País, através da advocacia do Direito Internacional dos Direitos Humanos.

O principal fator que leva essas denúncias ao âmbito da Comissão Interamericana é a insuficiência ou até mesmo a ausência de resposta por parte do Estado brasileiro, sendo que em ambos os períodos históricos, a maior parte das denúncias diz respeito a violações a direitos civis e/ou políticos. Isso revela um movimento ainda inexpressivo a respeito da apresentação para proteção de denúncias relacionadas à violação de direitos sociais, econômicos ou culturais.

Outro fator objetivo que fez com que houvesse um estímulo à proposição de ações internacionais junto à Comissão Interamericana foi a própria ratificação da Convenção Americana, a partir de 1992.

Sobre o aumento significativo dessas denúncias perante os órgãos da OEA,

[...] em grande parte, isso se deve à atuação de alguns movimentos sociais que profissionalizaram sua atuação. Além de investir na formação de redes de atores não estatais no continente, de estudar exaustivamente as legislações nacionais e internacionais em matéria de direitos humanos e de contratar advogados especializados, eles desenvolveram o conceito de "litígio estratégico ou paradigmático". A ideia é concentrar a atenção em casos exemplares e com grande impacto social, dando-lhes o máximo possível de visibilidade política, com o objetivo de obter "precedentes" no Sistema Interamericano de Proteção dos Direitos Humanos. O passo seguinte é pressionar os tribunais nacionais a acolher esses precedentes e os governos a adotar novas políticas sociais. Em outras palavras, o "litígio estratégico ou paradigmático" envolve a prática de uma advocacia mais engenhosa, que vai além do simples denuncismo, por parte dos movimentos sociais. Essa estratégia deu certo na Colômbia, Chile e Peru, países cujas Cortes superiores converteram em jurisprudência vários precedentes abertos na Comissão e na Corte Interamericana dos Direitos Humanos. (O BRASIL..., 2009).

O aumento dessas denúncias acaba por revelar uma questão positiva para o nosso País, qual seja, a de que o Brasil está fazendo parte de um processo que o levará para um avanço no tocante à proteção e efetivação dos direitos humanos. Isso porque, com essas

preponderantemente política, o que mitiga a pouca judicialidade que possui. Ou seja, como o caráter jurídico do Tribunal requer atuação no plano político, a tutela dos direitos distancia-se dos seus destinatários. Idealmente, o sistema deveria impor a obrigatoriedade da ação direta pelo particular, como é o caso no sistema regional europeu. Porém, mesmo que esse procedimento seja adotado pelo sistema africano, outros obstáculos poderão surgir entre o Tribunal e o indivíduo, e entre a decisão e sua execução por parte do Estado demandado. Tome-se como exemplo o recente caso sudanês: Em retaliação à decisão do TPI pela sua prisão, Omar Al Bashir, atual presidente do Sudão, expulsou as ONGs de direitos humanos e de ajuda humanitária do país. Perdeu-se, com isso, uma importante interface entre os indivíduos e o sistema regional africano, já que ONGs dessa natureza, além de atuarem como observadoras, desempenham a relevante função de viabilização de acesso ao sistema por meio de apoio técnico, jurídico e até mesmo material. Lembrando que a disparada maioria dos africanos é extremamente pobre e possui pouca ou nenhuma instrução, o acesso ao sistema sem algum tipo de apoio torna-se inviável, mesmo em países sem regimes autoritários”. 
denúncias crescentes, criam-se fatos políticos externos que passam a representar uma verdadeira pressão política interna, fazendo com que os governos e o Judiciário passem a despender mais esforços em prol dos direitos humanos. ${ }^{25}$

Denota-se que o sistema interamericano de proteção dos direitos humanos possui o condão de fortalecer a efetivação dos direitos humanos no Brasil. Isso porque esse sistema estabelece um padrão de atuação para os Estados, sendo que, ao serem desrespeitados esses parâmetros internacionais, torna-se automaticamente possível o direcionamento de comunicações dessas violações por parte dos indivíduos e das organizações não governamentais. Esse parâmetro de atuação internacional proporciona a tutela e a fiscalização do modo pelo qual os Estados defendem os direitos humanos.

O movimento crescente do "litígio estratégico ou paradigmático", também conhecido comumente na linguagem desse universo atinente às organizações não governamentais como advocacy, dentro do cenário brasileiro, revela o grande potencial transformador da dinâmica de proteção efetiva dos direitos humanos no País.

Assim mesmo, tem-se que a internacionalização dos direitos humanos ainda não está efetivamente completa, devido às mencionadas tensões e há diversas violações aos direitos humanos que restam impunes, como é o próprio caso do Estado brasileiro.

Apesar de grande parte da tarefa de consolidação do Direito Internacional dos Direitos Humanos pertencer ao Poder Judiciário - que, como explicitado anteriormente, ainda mostra-se resistente a algumas mudanças -, principalmente à Suprema Corte brasileira, enquanto guardiã da Constituição Federal, outra parcela também considerável do esforço se deve à própria sociedade civil, na exata medida de suas esferas de atuação.

Daí a importância também aqui ressaltada do papel das organizações não governamentais, que têm lançado mão de um processo de internacionalização dos direitos humanos, seja através de suas marcantes ações sociais, seja pela promoção do denominado "litígio estratégico ou paradigmático". Esse tipo de advocacia em prol dos direitos humanos tem dado mostras de um processo positivo de difusão dessa tarefa, pois os resultados em que se observa a condenação de nosso Estado perante a violação de direitos

25 Para Flávia Piovesan (2010, p. 350-351): “A experiência brasileira revela que a ação internacional tem também auxiliado a publicidade das violações de direitos humanos, o que oferece o risco do constrangimento político e moral ao Estado violador, e, nesse sentido, surge como significativo fator para a proteção dos direitos humanos. Ademais, ao enfrentar a publicidade das violações de direitos humanos, bem como as pressões internacionais, o Estado é praticamente 'compelido' a apresentar justificativas a respeito de sua prática. A ação internacional e as pressões internacionais podem, assim, contribuir para transformar uma prática governamental específica, no que se refere aos direitos humanos, conferindo suporte ou estímulo para reformas internas". 
humanos servem como elementos de pressão às autoridades dos três Poderes para amenizar a situação de nosso País diante dos holofotes internacionais.

Como exemplo da atuação marcante e eficaz desse tipo de advocacia a que as organizações não governamentais têm se dedicado, cita-se o mais recente caso que acaba de entrar para a história de nossa jurisprudência nacional, em que o Superior Tribunal de Justiça, em 27 de outubro de 2010, decide pela primeira vez federalizar um crime por violação a direitos humanos:

O Superior Tribunal de Justiça (STJ) decidiu ontem por 5 votos a 2 federalizar a investigação do assassinato do advogado e defensor de direitos humanos Manoel Bezerra de Mattos e de outros crimes relacionados. Mattos foi morto em 24 de janeiro do ano passado, depois de ter denunciado a existência de um grupo de extermínio atuando na divisa entre Pernambuco e Paraíba.

Foi a primeira decisão do gênero. Em 2004, estabeleceu-se o chamado Incidente de Deslocamento de Competência (IDC), que permite a federalização, mas nunca foi usado. Em 2005, o STJ negou o pedido para investigação federal da morte da irmã Dorothy Stang, assassinada no Pará. No dia 1..$^{\circ}$ de junho, quando Mattos faria 42 anos, ele teve seu nome citado no relatório da Organização das Nações Unidas (ONU) sobre execuções sumárias, que criticou o STJ pela demora na federalização.

Com a decisão, a investigação e o julgamento dos cinco suspeitos do assassinato de Mattos saem da alçada das autoridades locais e passam para a competência da Polícia Federal, do MPF e da Justiça Federal da Paraíba. A medida pode garantir maior isenção e segurança nos trabalhos. "É uma decisão histórica, que pode abrir caminho para que outros casos semelhantes sejam federalizados", disse a advogada Andressa Caldas, diretora executiva da Justiça Global, uma das organizações não governamentais que entraram com pedido para que a Procuradoria Geral da República levasse o caso ao STJ.

Nascido em Pernambuco, na cidade de Itambé, vizinha de Pedras de Fogo, na Paraíba, Mattos passou a trabalhar com direitos humanos na década de 1990, quando autoridades da divisa montaram um grupo de extermínio para matar suspeitos de roubos e furtos na região - incluindo crianças e adolescentes.

Em 2002, Mattos passou a ser ameaçado de morte, juntamente com outras quatro pessoas. Depois de ser procurada por ONGs, a Organização dos Estados Americanos (OEA) determinou que fossem tomadas medidas para proteger as testemunhas. Pouco foi feito e o advogado acabou assassinado sete anos depois.

De acordo com levantamento da promotora de Justiça Rosemary Souto Maior, da Comarca de Itambé, que atua na cidade desde 1994, ocorreram mais de 200 assassinatos só no lado pernambucano. "São casos que não foram investigados e acabaram registrados como de autoria desconhecida, uma vez que poucos têm coragem de denunciar."

O grupo de extermínio continua atuante na fronteira. A mãe de Mattos, Nair Ávila, e a promotora estão sofrendo ameaças de morte. Nair esteve presente ontem no julgamento e ficou emocionada com a decisão da Justiça. "Fiquei muito feliz com a decisão, que me leva a acreditar mais na Justiça. Tenho orgulho de meu filho, que sempre foi um homem de bem.” (MANSO, 2010).

Espera-se que, a partir das condenações resultantes desses processos levados às cortes internacionais, sejam tomadas, em larga escala, medidas internas a reforçar, nesses casos, a insuficiência de nossa legislação interna perante os direitos lesados, contribuindo para que a nossa democracia se distancie cada vez mais de suas remanescentes marcas 
autoritárias resultantes de uma época em que ainda não se cogitava a formação de um Estado Democrático de Direito. 


\section{A EDUCAÇÃO E OS PACTOS INTERNACIONAIS}

Conforme descrito no tópico inaugural, a instrução foi garantida pela Declaração Universal dos Direitos Humanos das Nações Unidas de 1948, em seu artigo $26^{26}$, ao lado de outros direitos inerentes ao homem (ISHAY, 2006, p. 654).

$\mathrm{Na}$ Convenção Europeia para a Proteção dos Direitos Humanos e das Liberdades Fundamentais, de 04 de novembro de $1950^{27}$, a educação aparece no primeiro de seus oito protocolos, denominado: "Primeiro Protocolo à Convenção para a Proteção dos Direitos Humanos e das Liberdades Fundamentais" firmado em Paris, no ano de 1952 (ISHAY, 2006, p. 665):

Artigo $2^{\circ}$ : A ninguém pode ser negado o direito à instrução. $\mathrm{O}$ Estado, no exercício das funções que tem de assumir no campo da educação e do ensino, respeitará o direito dos pais a assegurar aquela educação e ensino consoante as suas convicções religiosas e filosóficas.

Já no Pacto Internacional das Nações Unidas sobre os Direitos Econômicos, Sociais e Culturais de 1966 (Pidesc), a educação encontra-se detalhadamente descrita e assegurada em seus artigos 13 e $14^{28}$ (ISHAY, 2006, p. 694-696), embora reafirme o conteúdo descrito anteriormente na Declaração Universal dos Direitos Humanos.

26 Artigo 26

“1. Toda pessoa tem direito à instrução. A instrução será gratuita, pelo menos nos graus elementares e fundamentais. A instrução elementar será obrigatória. A instrução técnico-profissional será acessível a todos, bem como a instrução superior, esta baseada no mérito.

2. A instrução será orientada no sentido do pleno desenvolvimento da personalidade humana e do fortalecimento do respeito pelos direitos humanos e pelas liberdades fundamentais. A instrução promoverá a compreensão, a tolerância e a amizade entre todas as nações e grupos raciais ou religiosos, e coadjuvará as atividades das Nações Unidas em prol da manutenção da paz.

3. Os pais têm prioridade de direito na escolha do gênero de instrução que será ministrada a seus filhos". (ISHAY, 2006, p. 654).

27 A sua entrada em vigor ocorreu somente em 3 de setembro de 1953.

28 Artigo 13

“1. Os Estados signatários do presente Pacto reconhecem o direito de toda pessoa à educação. Concordam em que a educação deverá visar ao pleno desenvolvimento da personalidade humana e do seu senso de dignidade e a fortalecer o respeito pelos direitos humanos e liberdades fundamentais. Concordam ainda que a educação deverá capacitar todas as pessoas a participar efetivamente de uma sociedade livre, favorecer a compreensão, a tolerância e a amizade entre todas as nações e entre todos os grupos raciais, étnicos ou religiosos e promover as atividades das Nações Unidas em prol da manutenção da paz.

2. Os Estados signatários do presente Pacto reconhecem que, com o objetivo de assegurar o pleno exercício desse direito:

a. a educação primária deverá ser obrigatória e acessível gratuitamente a todos;

b. a educação secundária em suas diferentes formas, inclusive a educação secundária técnica e profissional, deverá ser generalizada e tornar-se acessível a todos, por todos os meios apropriados e, principalmente, pela implantação progressiva do ensino gratuito; 
Mas como bem ressaltado por Flávia Piovesan (2009, p. 176), o objetivo principal deste Pacto foi instituir preceitos jurídicos capazes de obrigar os Estados-membros a cumprirem suas obrigações legais, sob pena de responsabilização internacional. Os direitos ali elencados constituem, portanto, deveres impostos aos Estados, cuja realização deve se dar de forma progressiva.

Isso significa que os direitos econômicos, sociais e culturais são programáticos, ou seja, estão sujeitos a políticas públicas para a sua realização. Além disso, sua aplicação deverá ocorrer de maneira progressiva, pois dependem, para a sua implementação, de um mínimo de recursos econômicos disponível, além de contar com o auxílio econômico de outros países $^{29}$.

Entretanto, para cada um desses direitos constantes no Pidesc, os Estados-partes devem garantir o seu núcleo essencial mínimo, conforme orientação do Comitê de Direitos Econômicos, Sociais e Culturais, criado especificamente para o auxílio nesta tarefa.

Outro mecanismo criado no contexto do Pidesc para a efetivação desses direitos consiste na elaboração de relatórios por conta dos Estados-membros, que passarão a ser objeto de investigação da presente pesquisa, com vistas a se concluir sobre a real efetivação da educação como um direito humano em nosso contexto atual.

c. a educação de nível superior deverá igualmente tornar-se acessível a todos, com base na capacidade de cada um, por todos os meios apropriados e, principalmente, pela implantação progressiva do ensino gratuito;

$d$. dever-se-á fomentar e intensificar, na medida do possível, a educação de base para aquelas pessoas que não receberam educação primária ou não concluíram o ciclo completo de educação primária;

$e$. será preciso prosseguir ativamente o desenvolvimento de uma rede escolar em todos os níveis de ensino, implantar um sistema adequado de bolsas de estudo e melhorar continuamente as condições materiais do corpo docente.

3. Os Estados signatários do presente Pacto comprometem-se a respeitar a liberdade dos pais e, quando for o caso, dos tutores legais de escolher para seus filhos escolas distintas daquelas criadas pelas autoridades públicas, sempre que atendam aos padrões mínimos de ensino prescritos ou aprovados pelo Estado, e de fazer com que seus filhos venham a receber educação religiosa ou moral que esteja de acordo com suas próprias convicções.

4. Nenhuma das disposições do presente artigo poderá ser interpretada no sentido de restringir a liberdade de indivíduos e de entidades de criar e dirigir instituições de ensino, desde que respeitados os princípios enunciados no parágrafo $1^{\circ}$ do presente artigo e que essas instituições observem os padrões mínimos prescritos pelo Estado.

Artigo 14

Todo Estado signatário do presente Pacto que, no momento de sua adesão ao Pacto, ainda não tenha garantido em seu próprio território ou em território sob a sua jurisdição a obrigatoriedade ou a gratuidade da educação primária, se compromete a elaborar e a adotar, dentro de um prazo de dois anos, um plano de ação detalhado destinado à implementação progressiva, dentro de um número razoável de anos estabelecido no próprio plano, do princípio da educação primária obrigatória e gratuita para todos". (ISHAY, 2006, p. 654).

29 Nesse sentido, ainda, Flávia Piovesan (2009, p. 180-181) acrescenta que: "da obrigação da progressividade na implementação dos direitos econômicos, sociais e culturais decorre a chamada cláusula de proibição do retrocesso social, na medida em que é vedado aos Estados retroceder no campo da implementação desses direitos. Vale dizer, a progressividade dos direitos econômicos, sociais e culturais proíbe o retrocesso ou a redução de políticas públicas voltadas à garantia de tais direitos”. 
Esses relatórios são exigidos por ambos os Pactos (Direitos Civis e Políticos e Direitos Econômicos, Sociais e Culturais), devendo conter as medidas adotadas pelo Estado-parte para a concretização dos direitos neles presentes. Faz-se necessário, ainda, trazer os obstáculos enfrentados neste processo de cumprimento das obrigações inscritas no Pidesc. (PIOVESAN, 2009, p. 179).

A partir disso, os Estados-partes deverão encaminhar os seus relatórios ao Secretário-Geral das Nações Unidas e, em seguida, este enviará cópia ao Conselho Econômico e Social para apreciação. Vale ressaltar que este Conselho, por sua vez, implementou um Comitê sobre Direitos Econômicos, Sociais e Culturais com competência para examinar os relatórios enviados pelos Estados ${ }^{30}$.

Naquele mesmo ano da criação do Pidesc, foi também criado o Pacto Internacional das Nações Unidas sobre os Direitos Civis e Políticos, sendo que o Brasil ratificou ambos os Pactos de 1966 por meio do Decreto Legislativo n. ${ }^{\circ}$ 226, de 12 de dezembro de 1991.

Diferentemente do Pidesc, os direitos elencados no Pacto dos Direitos Civis e Políticos são direcionados aos indivíduos, possuindo a característica da autoaplicabilidade, ou seja, seus efeitos podem ser sentidos de maneira imediata.

Outro documento fundamental para a consolidação do direito à educação no âmbito internacional foi a Convenção Americana de Direitos Humanos, assinada em 22 de novembro de 1969, em San Jose da Costa Rica, cuja entrada em vigor se deu somente em 18 de julho de 1978 (ISHAY, 2006, p. 712). No capítulo III deste mesmo documento, especificamente no artigo $26^{31}$, encontra-se assegurado o desenvolvimento progressivo dos direitos econômicos, sociais e culturais, incluindo-se entre eles o direito à educação.

30 Ainda sobre a sistemática da implementação dos direitos advindos do Pidesc, Flávia Piovesan (2009, p. 179-180) complementa: "diversamente do Pacto dos Direitos Civis e Políticos, que institui o Comitê de Direitos Humanos como órgão principal de monitoramento, o Pacto dos Direitos Econômicos, Sociais e Culturais não cria um Comitê próprio, que, como realçado, foi estabelecido posteriormente pelo Conselho Econômico e Social. Ainda diversamente do Pacto dos Direitos Civis, o Pacto dos Direitos Sociais não estabelece o mecanismo de comunicação interestatal; tampouco, mediante Protocolo Facultativo, permite a sistemática das comunicações individuais. Em suma, o mecanismo de proteção dos direitos sociais, econômicos e culturais continua a se restringir à sistemática dos relatórios, embora a Declaração de Viena tenha recomendado a incorporação do direito de petição a esse Pacto, mediante a adoção de protocolo adicional. Para fortalecer a efetividade dos direitos econômicos, sociais e culturais, a Conferência de Viena de 1993 recomendou ainda o exame de outros critérios, como a aplicação de um sistema de indicadores, para medir o progresso alcançado na realização dos direitos previstos no Pacto Internacional de Direitos Econômicos, Sociais e Culturais. Recomendou também seja empreendido um esforço harmonizado, visando a garantir o reconhecimento dos direitos econômicos, sociais e culturais nos planos nacional, regional e internacional".

31 Artigo 26. "Desenvolvimento progressivo

Os Estados signatários comprometem-se a adotar as providências, tanto no âmbito interno, como mediante cooperação internacional, especialmente econômica e técnica, a fim de conseguir progressivamente a plena efetividade dos direitos que decorrem das normas econômicas, sociais e sobre educação, ciência e cultura, constantes da Carta da Organização dos Estados Americanos, reformada pelo 
Já o Protocolo Adicional à Convenção Americana de Direitos Humanos sobre os Direitos Econômicos, Sociais e Culturais, que ficou conhecido simplesmente como Protocolo de San Salvador, datado de 17 de novembro de $1988^{32}$ veio reafirmar o constante no conteúdo do Pidesc com relação ao direito à educação, sendo que o grande diferencial trazido pelo primeiro foi a criação da Comissão Interamericana de Direitos Humanos, responsável por investigar denúncias ali trazidas de violações de direitos, e da respectiva Corte Interamericana de Direitos Humanos, cuja atribuição é o julgamento daquelas violações assim consideradas pela Comissão (GRACIANO, 2005, p. 26).

Especificamente com relação ao direito à educação, constante no artigo $13^{33}$ do Protocolo de San Salvador, instituiu-se a prerrogativa de apresentação de petição individual como instrumento direcionado especialmente para a sua salvaguarda em caso de violação, muito embora o que se observa é que o mecanismo utilizado para a proteção desses direitos tem se resumido apenas à confecção dos referidos relatórios (PIOVESAN, 2009, p. 180-181).

Com a internacionalização dos direitos humanos, surge a possibilidade de tanto os indivíduos como as organizações da sociedade civil recorrerem a um tribunal internacional

Protocolo de Buenos Aires, na medida dos recursos disponíveis, por via legislativa ou por outros meios apropriados". (ISHAY, 2006, p. 654).

32 Esse Protocolo foi criado por meio da Conferência Interamericana de São Salvador, tendo sido ratificado em 1966 pelo Estado Brasileiro.

33 Artigo 13 - "Direito à educação

1. Toda pessoa tem direito à educação.

2. Os Estados-partes neste Protocolo convêm em que a educação deverá orientar-se para o pleno desenvolvimento da personalidade humana e do sentido de sua dignidade e deverá fortalecer o respeito pelos direitos humanos, pelo pluralismo ideológico, pelas liberdades fundamentais, pela justiça e pela paz. Convêm, também, em que a educação deve capacitar todas as pessoas para participar efetivamente de uma sociedade democrática e pluralista, conseguir uma subsistência digna, favorecer a compreensão, a tolerância e a amizade entre todas as nações e todos os grupos raciais, étnicos ou religiosos e promover as atividades da manutenção da paz.

3. Os Estados-partes neste protocolo reconhecem que, a fim de conseguir o pleno exercício do direito à educação:

a) $\mathrm{O}$ ensino de primeiro grau deve ser obrigatório e acessível a todos gratuitamente;

b) $\mathrm{O}$ ensino de segundo grau, em suas diferentes formas, inclusive o ensino técnico e profissional de segundo grau, deve ser generalizado e tornar-se acessível a todos, pelos meios apropriados e, especialmente, pela implantação progressiva do ensino gratuito;

c) $\mathrm{O}$ ensino superior deve tornar-se igualmente acessível a todos, de acordo com a capacidade de cada um, pelos meios que forem apropriados e, especialmente, pela implantação progressiva do ensino gratuito;

d) Deve-se promover ou intensificar, na medida do possível, o ensino básico para as pessoas que não tiverem recebido ou terminado o ciclo completo de instruções do primeiro grau;

e) Deverão ser estabelecidos programas de ensino diferenciado para os deficientes, a fim de proporcionar instrução especial e formação a pessoas com impedimentos físicos ou deficiência mental.

4. De acordo com a legislação interna dos Estados-partes, os pais terão direito a escolher o tipo de educação a ser dada aos seus filhos, desde que seja de acordo com os princípios enunciados acima.

5. Nada do disposto neste protocolo poderá ser interpretado como restrição da liberdade dos particulares e entidades de estabelecer e dirigir instituições de ensino, de acordo com a legislação interna dos Estados-partes". (PIOVESAN, 2009, p. 514-515). 
toda vez que a Justiça (o direito interno) de um país for insuficiente para fazer com que determinado direito seja concretizado, em caso de desatendimento, ou até mesmo que o autor da violação a um direito seja punido.

A educação, então, passou a ser reconhecida no âmbito internacional como um assunto que interessa a todas as nações, e cujo descumprimento acarreta sanções perante o Tribunal Internacional, e não somente no âmbito interno dos Estados.

A análise do ponto de vista da educação constante nesses documentos permite concluir que a obrigação dos Estados consiste em oferecer instrução primária ou fundamental, garantindo a progressividade e evitando retrocessos. Mas, por outro lado, não há nada que garanta a questão da universalização desse direito (GRACIANO, 2005, p. 27).

Nesse sentido, nota-se que os avanços atuais na área da educação no Brasil decorrem mais dos movimentos das organizações da sociedade civil - progressivamente assumidos pelos Estados - do que propriamente do cumprimento de tais acordos internacionais (SPOSITO, 1984).

Isto porque, na prática, ainda são toleradas as frequentes violações aos direitos sociais, econômicos e culturais, cujo peso - por conta das tensões que percorrem os direitos humanos e sua interpretação, tal como analisadas anteriormente - parece bem menor se comparado às violações de direitos civis e políticos, com menor nível de tolerância internacional. $^{34}$

\subsection{A educação nas normas e planos de educação nacionais}

Tal como vimos no primeiro tópico, a educação aparece pela primeira vez na Constituição Imperial de 1824, ligada à noção de cidadania. Este era o maior entrave à sua efetividade, pois a maioria da população daquela época era escrava e, portanto, não era considerada cidadã. Com isso, a educação era privilégio de poucos, enquanto que a imensa maioria era analfabeta.

34 Sobre a desigualdade de tratamento no âmbito internacional entre os direitos civis e políticos e os direitos econômicos, sociais e culturais, Flávia Piovesan (2009, p. 184) considera que: “em geral, a violação aos direitos sociais, econômicos e culturais é resultado tanto da ausência de forte suporte e intervenção governamental como da ausência de pressão internacional em favor dessa intervenção. É, portanto, um problema de ação e prioridade governamental e implementação de políticas públicas, que sejam capazes de responder a graves problemas sociais.

Acrescente-se que a globalização econômica tem agravado ainda mais as desigualdades sociais, aprofundando as marcas da pobreza absoluta e da exclusão social". 
No entanto, ela permaneceu inscrita nas constituições republicanas brasileiras, onde foi se adequando ao tempo e ao meio em que se encontrava situada, até ser reconhecida como um direito declarado.

A previsão nos artigos 205 a 214 da Constituição Federal de 1988 fez surgir, posteriormente, a Lei de Diretrizes e Bases da Educação Nacional n. ${ }^{\circ}$ 9.394, de 20 de dezembro de 1996, a fim de regulamentar os referidos dispositivos.

Conforme afirma Ghiraldelli Júnior (2006, p. 170-173), a LDB acabou sendo uma mistura entre o projeto oriundo dos debates dos setores envolvidos com a educação brasileira, sindicatos, associações de professores e o projeto do senador Darcy Ribeiro. Para ele, um dos pontos fracos da LDB é a questão da democratização do ensino, pois poderia ter-se dado maior ênfase ao ensino de qualidade.

Além disso, ao estabelecer um núcleo comum e outro diversificado com relação ao conteúdo do ensino a ser praticado nas escolas, a LDB demonstrou não ter sido autoritária, permitindo com que se ampliasse a literatura de um modo geral.

No que diz respeito aos pontos comuns a serem aplicados em todo o território, a LDB conta com o Título II, em que estão devidamente estabelecidos os princípios e fins da educação nacional:

Art. $2^{\circ}$ A educação, dever da família e do Estado, inspirada nos princípios de liberdade e nos ideais de solidariedade humana, tem por finalidade o pleno desenvolvimento do educando, seu preparo para o exercício da cidadania e sua qualificação para o trabalho.

Art. $3^{\circ} \mathrm{O}$ ensino será ministrado com base nos seguintes princípios:

I - igualdade de condições para o acesso e permanência na escola;

II - liberdade de aprender, ensinar, pesquisar e divulgar a cultura, o pensamento, a arte e o saber;

III - pluralismo de idéias (sic) e de concepções pedagógicas;

IV - respeito à liberdade e apreço à tolerância;

$\mathrm{V}$ - coexistência de instituições públicas e privadas de ensino;

VI - gratuidade do ensino público em estabelecimentos oficiais;

VII - valorização do profissional da educação escolar;

VIII - gestão democrática do ensino público, na forma desta Lei e da legislação dos sistemas de ensino;

IX - garantia de padrão de qualidade;

$\mathrm{X}$ - valorização da experiência extra-escolar;

XI - vinculação entre a educação escolar, o trabalho e as práticas sociais. (BITTAR; ALMEIDA, 2010, p. 120-121).

Já o artigo 15 da LDB, por exemplo, refere-se expressamente à "autonomia pedagógica":

Art. 15. Os sistemas de ensino assegurarão às unidades escolares públicas de educação básica que os integram progressivos graus de autonomia pedagógica e 
administrativa e de gestão financeira, observadas as normas gerais de direito financeiro público. (BITTAR; ALMEIDA, 2010, p. 83).

No Capítulo II, que trata da educação básica, ficam evidenciadas a parte comum e a diversificada quanto ao conteúdo do ensino nos ambientes escolares:

Art. 26. Os currículos do ensino fundamental e médio devem ter uma base nacional comum, a ser complementada, em cada sistema de ensino e estabelecimento escolar, por uma parte diversificada, exigida pelas características regionais e locais da sociedade, da cultura, da economia e da clientela. (BITTAR; ALMEIDA, 2010, p. 125).

Quanto à educação superior, seus cursos e programas estão previstos em regulamento específico do governo, bem como nas demais disposições contidas a exemplo do artigo 44 da LDB:

Art. 44. A educação superior abrangerá os seguintes cursos e programas: (Regulamento) <http://www.planalto.gov.br/CCIVIL/decreto/2001/D3860.htm> I - cursos sequenciais por campo de saber, de diferentes níveis de abrangência, abertos a candidatos que atendam aos requisitos estabelecidos pelas instituições de ensino;

II - de graduação, abertos a candidatos que tenham concluído o ensino médio ou equivalente e tenham sido classificados em processo seletivo;

III - de pós-graduação, compreendendo programas de mestrado e doutorado, cursos de especialização, aperfeiçoamento e outros, abertos a candidatos diplomados em cursos de graduação e que atendam às exigências das instituições de ensino;

IV - de extensão, abertos a candidatos que atendam aos requisitos estabelecidos em cada caso pelas instituições de ensino. (BITTAR; ALMEIDA, 2010, p. 128).

No entanto, a educação superior também goza de autonomia, estando ela reafirmada em várias passagens do capítulo da Lei que lhe é destinado, a exemplo do artigo 53 da LDB:

Art. 53. No exercício de sua autonomia, são asseguradas às universidades, sem prejuízo de outras, as seguintes atribuições:

I - criar, organizar e extinguir, em sua sede, cursos e programas de educação superior previstos nesta Lei, obedecendo às normas gerais da União e, quando for o caso, do respectivo sistema de ensino; (Regulamento) <http://www.planalto.gov.br/CCIVIL/decreto/2001/D3860.htm>

II - fixar os currículos dos seus cursos e programas, observadas as diretrizes gerais pertinentes;

III - estabelecer planos, programas e projetos de pesquisa científica, produção artística e atividades de extensão;

IV - fixar o número de vagas de acordo com a capacidade institucional e as exigências do seu meio;

$\mathrm{V}$ - elaborar e reformar os seus estatutos e regimentos em consonância com as normas gerais atinentes;

VI - conferir graus, diplomas e outros títulos;

VII - firmar contratos, acordos e convênios; 


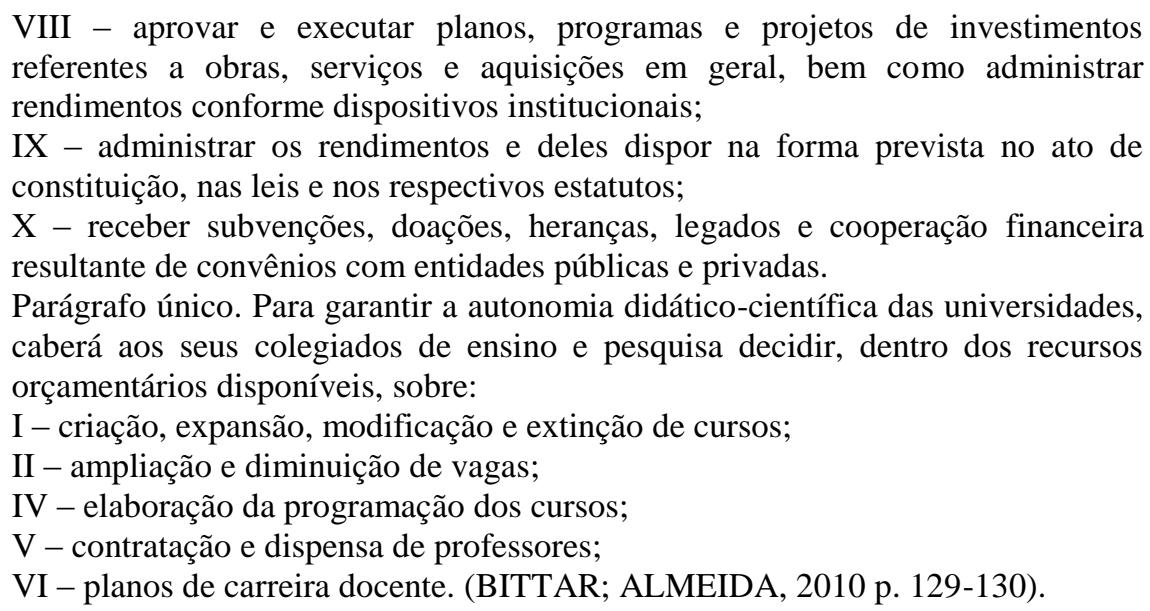

Do ponto de vista financeiro, a LDB fixou prazos para o repasse de recursos para a educação por parte da União, dos Estados e dos Municípios, sob pena de se incorrer em crime, caso esta regra viesse a ser violada.

Após o advento da LDB, o Poder Executivo enviou ao Congresso Nacional a Mensagem n. ${ }^{\circ}$ 180/98, referente ao projeto de lei que veio instituir o Plano Nacional de Educação (Lei 10.172/2001).

Esse plano traçou objetivos e prioridades a serem atendidos no período compreendido entre 2001 e 2011. Os principais objetivos descritos pelo Plano Nacional de Educação são os seguintes:

$[\ldots]$

- a elevação global do nível de escolaridade da população;

- a melhoria da qualidade do ensino em todos os níveis;

- a redução das desigualdades sociais e regionais no tocante ao acesso e à permanência, com sucesso, na educação pública e

- democratização da gestão do ensino público, nos estabelecimentos oficiais, obedecendo aos princípios da participação dos profissionais da educação na elaboração do projeto pedagógico da escola e a participação das comunidades escolar e local em conselhos escolares ou equivalentes. (BITTAR; ALMEIDA, 2010, p. 137-138).

O PNE elegeu também as seguintes prioridades, segundo o critério relativo à limitação dos recursos financeiros, bem como o desafio lento e gradativo de se construir uma educação compatível, na extensão e na qualidade, à dos países desenvolvidos:

1. Garantia de ensino fundamental obrigatório de oito anos a todas as crianças de 7 a 14 anos, assegurando o seu ingresso e permanência na escola e a conclusão desse ensino. [...]

2. Garantia de ensino fundamental a todos os que a ele não tiveram acesso na idade própria ou que não o concluíram. [...]

3. Ampliação do atendimento nos demais níveis de ensino [...]

4. Valorização dos profissionais da educação. 
5. Desenvolvimento de sistemas de informação e de avaliação em todos os níveis e modalidades de ensino. (BITTAR; ALMEIDA, 2010, p. 138).

Além disso, o PNE define: "as diretrizes para a gestão e o financiamento da educação", "as diretrizes e metas para cada nível e modalidade de ensino" e as "diretrizes e metas para a formação e valorização do magistério e demais profissionais da educação, nos próximos dez anos".

Ghiraldelli Júnior (2006) aponta como uma das grandes qualidades deste plano o fato de ter deflagrado abertamente qual era a verdadeira situação da educação brasileira. $\mathrm{O}$ PNE mostrou alguns dados animadores, como um bom crescimento das matrículas no País entre 1991 e 1996, o que apontava para uma diminuição das diferenças regionais, mas atestou diversos problemas ali apontados, destacando-se, por exemplo: "o PNE contou que a partir de 1993 as matrículas praticamente se fixaram na casa de 4,2 milhões, diante de um aumento populacional considerável e diante da concentração de renda que fez crescer o número de "famílias abaixo do nível de pobreza" (GHIRALDELLI JÚNIOR, 2006, p. 196-198).

O PNE relatou, ainda, as difíceis condições nas escolas, sendo que, em sua própria avaliação (GHIRALDELLI JÚNIOR, 2006, p. 199),

[...] o fato de ainda haver crianças fora da escola não teria como causa determinante o déficit de vagas, mas estaria relacionado à precariedade do ensino e às condições de exclusão e marginalidade social em que vivem segmentos da população brasileira. Não bastaria, então, somente abrir vagas. Programas paralelos de assistência a famílias seriam fundamentais para o acesso à escola e a permanência nela da população muito pobre, que seria dependente do trabalho infantil.

O quadro do ensino médio, segundo o PNE, era o mais calamitoso. O documento revelou um número reduzido de matrículas neste setor. Apenas 30,8\% da população de 15 a 17 anos tinha acesso a esse nível de ensino. No entanto, não haveria falta de escolas, pois a oferta de vagas na primeira série teria sido maior do que a procura. $\mathrm{O}$ que estava ocorrendo, pelas análises dos gráficos dispostos pelo PNE, é que os alunos, devido a um ensino fundamental fraco, estariam abandonando e/ou repetindo as séries do ensino médio.

De acordo com o PNE, alguns dos fatores que levaram a esta precária situação se devem ao fato de que

[...] o ensino médio convive, também, com alta seletividade interna. Se os alunos estão chegando em maior número a esse nível de ensino, os índices de conclusão nas últimas décadas sinalizam que há muito a ser feito. Na coorte 1970-73, 74\% dos que iniciavam o ensino médio conseguiam concluí-lo; na coorte 1977-80, este índice caiu para 50,8\%; na de 1991-94, para 43,8\%.

Causas externas ao sistema educacional contribuem para que adolescentes e jovens se percam pelos caminhos da escolarização, agravadas por dificuldades da própria organização da escola e do processo ensino-aprendizagem. Os números 
do abandono e da repetência, apesar da melhoria dos últimos anos, ainda são bastante desfavoráveis [...].

[...] Entretanto, no caso do ensino médio, não se trata apenas de expansão. Entre os diferentes níveis de ensino, esse foi o que enfrentou, nos últimos anos, a maior crise em termos de ausência de definição dos rumos que deveriam ser seguidos em seus objetivos e em sua organização. Um aspecto que deverá ser superado com a implementação das Novas Diretrizes Curriculares para o ensino médio e com programas de formação de professores, sobretudo nas áreas de Ciências e Matemática. (BITTAR; ALMEIDA, 2010, p. 149).

O próprio texto do plano, no tocante ao ensino médio, revela que a educação média é especialmente vulnerável à desigualdade social, deflagrando-se constantemente o conflito entre as orientações de cunho econômico (profissionalizantes) e as de cunho humanista (acadêmicas):

[...] a tensão expressa nos privilégios e nas exclusões decorre da origem social. Em vista disso, o ensino médio proposto neste plano deverá enfrentar o desafio dessa dualidade com oferta de escola média de qualidade a toda a demanda. Uma educação que propicie aprendizagem de competências de caráter geral, forme pessoas mais aptas a assimilar mudanças, mais autônomas em suas escolhas, que respeitem as diferenças e superem a segmentação social. (BITTAR; ALMEIDA, 2010, p. 150).

Constatadas essas dificuldades, o PNE se propõe a implementar, no item referente às diretrizes, um ensino médio que

[...] deverá permitir aquisição de competências relacionadas ao pleno exercício da cidadania e da inserção produtiva: auto-aprendizagem; percepção da dinâmica social e capacidade para nela intervir; compreensão dos processos produtivos; capacidade de observar, interpretar e tomar decisões; domínio de aptidões básicas de linguagens, comunicação, abstração; habilidades para incorporar valores éticos de solidariedade, cooperação e respeito às individualidades.

[...] As metas de expansão da oferta e de melhoria da qualidade do ensino médio devem estar associadas, de forma clara, a diretrizes que levem à correção do fluxo de alunos na escola básica, hoje com índices de distorção idade-série inaceitáveis. (BITTAR; ALMEIDA, 2010, p. 150).

Vale ressaltar que o PNE realizou também um importante diagnóstico referente à educação superior, principalmente com relação ao acesso, comparando a situação brasileira com o restante dos países da América Latina. Percebe-se, pela leitura do documento, que o Brasil encontrava-se em situação desfavorável a países como o Chile (20,6\%), Venezuela (26\%) e Bolívia (20,6\%), mesmo considerando o setor privado (BITTAR; ALMEIDA, 2010, p. 152-153).

Além desta legislação específica destinada à educação, há que se mencionar a presença da educação no Programa Nacional de Direitos Humanos, que se encontra atualmente em sua terceira versão. 
O PNDH-I surgiu pela primeira vez em 1996, através do Decreto n. ${ }^{\circ} 1.904$, quando o Governo Federal passou a atender a determinação da Conferência Mundial de Direitos Humanos, ocorrida em Viena no ano de 1993 (GRACIANO, 2005, p. 35 e ss.).

Logo na Introdução desta primeira edição do Programa, apesar de se admitir a indivisibilidade dos direitos humanos, já há um óbice colocado pelo próprio Governo à execução destes direitos, calcado na escassez de recursos. ${ }^{35}$

Além disso, o Programa esvazia a função do Estado de realizar políticas públicas para a promoção dos direitos humanos, ficando este papel totalmente a cargo da sociedade civil, a saber:

[...] o Programa contempla, igualmente, iniciativas que fortalecem a atuação das organizações da sociedade civil, para a criação e consolidação de uma cultura de direitos humanos. Nada melhor para atingir esse objetivo do que atribuir a essas organizações uma responsabilidade clara na promoção dos direitos humanos, especialmente nas iniciativas voltadas para a educação e a formação da cidadania. (BITTAR; ALMEIDA, 2010, p. 44).

Dentre as propostas de ações governamentais existentes nesse Programa, a educação aparece com roupagens diversas, mais ligada à ideia de "educação em direitos humanos", e não como um direito humano em si.

Em primeiro lugar, surge como um instrumento genérico para a construção e aperfeiçoamento da própria sociedade, em um tópico intitulado: "Educação e Cidadania. Bases para uma cultura de Direitos Humanos", cujo subitem trata da "Produção e Distribuição de Informações e Conhecimento", onde a meta se caracteriza, a

Curto Prazo: criar e fortalecer programas de educação para o respeito aos direitos humanos nas escolas de primeiro, segundo e terceiro grau, através do sistema de "temas transversais" nas disciplinas curriculares, atualmente adotado pelo Ministério da Educação e do Desporto, e através da criação de uma disciplina sobre direitos humanos. (BITTAR; ALMEIDA, 2010, p. 54).

Novamente a educação aparece, porém, como forma de treinamento para pessoas ligadas à área da segurança, entre as metas de "curto prazo" do item: "Conscientização e Mobilização pelos Direitos Humanos”, consistente em

35 INTRODUÇÃO - A natureza do Programa Nacional de Direitos Humanos:

"O Programa Nacional de Direitos Humanos, como qualquer plano de ação que se pretenda exequível, deve explicitar objetivos definidos e precisos. Assim, sem abdicar de uma compreensão integral e indissociável dos direitos humanos, o Programa atribui maior ênfase aos direitos civis, ou seja, os que ferem mais diretamente a integridade física e o espaço de cidadania de cada um". (BITTAR; ALMEIDA, 2010, p. 44). 
[...] apoiar programas de informação, educação e treinamento de direitos humanos para profissionais de direito, policiais, agentes penitenciários e lideranças sindicais, associativas e comunitárias, para aumentar a capacidade de proteção e promoção dos direitos humanos na sociedade brasileira. (BITTAR; ALMEIDA, 2010, p. 54).

Por último, a educação aparece com a conotação de servir para a reinserção dos detentos na sociedade, no tópico referente às penas privativas de liberdade, cuja meta a "médio prazo" é de "promover programas de educação, treinamento profissional e trabalho para facilitar a reeducação e recuperação do preso" (BITTAR; ALMEIDA, 2010, p. 48).

Conclui-se, portanto, que o tratamento dedicado à educação ficou muito aquém de ser considerada por si só como um direito humano. Não há qualquer passagem em que ela seja reconhecida de tal forma, mas apenas com o objetivo de servir de instrumento para o alcance de outro direito.

No entanto, em 2002, o Programa Nacional de Direitos Humanos foi revisado e atualizado em relação à sua edição anterior. O PNDH-II teve como principal mudança a equiparação de valores entre os direitos civis e políticos e os direitos econômicos, sociais e culturais, conforme se verifica da leitura de seu item introdutório (BITTAR; ALMEIDA, 2010, p. 58):

[...] o processo de revisão do PNDH constitui um novo marco na promoção e proteção dos direitos humanos no País, ao elevar os direitos econômicos, sociais e culturais ao mesmo patamar de importância dos direitos civis e políticos, atendendo a reivindicação formulada pela sociedade civil por ocasião da IV Conferência Nacional de Direitos Humanos, realizada em 13 e 14 de maio de 1999 na Câmara dos Deputados, em Brasília.

O PNDH-II traz um tópico denominado: "Garantia do Direito à Educação", cujas metas específicas nesse sentido vão desde o n. 295 ao n. ${ }^{\circ} 327$. Além das previsões do programa anterior e daquelas constantes na Constituição Federal, destaca-se uma maior preocupação com as questões de acesso e permanência no sistema escolar, bem como a melhoria da qualidade do ensino público ${ }^{36}$.

36 Como exemplo disso, cita-se: "Garantia do Direito à Educação:

[...]

300. Incrementar a qualidade do ensino, com intervenções em segmentos determinantes do sucesso escolar.

301. Consolidar um sistema de avaliação dos resultados do ensino público e privado em todo o país.

[...]

305. Garantir a universalização, a obrigatoriedade e a qualidade do ensino fundamental, estimulando a adoção da jornada escolar ampliada, a valorização do magistério e a participação da comunidade na gestão das escolas, e garantindo apoio ao transporte escolar. 
Atualmente, o Brasil conta com a terceira edição do Programa Nacional de Direitos Humanos (PNDH-III), formalizado em Decreto n. ${ }^{\circ}$ 7.037, de 21 de dezembro de 2009, atualizado pelo Decreto n. ${ }^{\circ} 7.177$, de 12 de maio de 2010 .

Conforme descrito em sua apresentação, uma das inovações trazidas por este programa foi sua proposição por 31 ministérios. O PNDH-III foi o resultado das resoluções da $11^{\text {a }}$ Conferência Nacional de Direitos Humanos e propostas aprovadas em diversas conferências que versam sobre o tema, desde 2003. Nessa Conferência, optou-se por uma metodologia onde as discussões giraram em torno de eixos orientadores, e não por temas específicos, como era feito nos programas anteriores (BRASIL, 2010d, p. 16).

Nele percebe-se, ainda, a presença esparsa da educação em seus diversos eixos temáticos, porém, ainda é vista como um instrumento para a garantia de outros direitos igualmente importantes, mas não como um direito humano propriamente dito.

Por outro lado, um importante exemplo de legislação estrangeira que traz em seu corpo, bem marcado e definido, o lugar da educação dentre os direitos humanos é a Lei de Educação do Uruguai (n. ${ }^{\circ} 18.437$, de 12 de dezembro de 2008).

Logo no Título I, encontram-se as definições, finalidades e orientações gerais da educação naquele país, sendo que o artigo $1^{\circ}$ chega a ser o mais importante dispositivo deste diploma, por tratar a educação como um direito humano fundamental ${ }^{37}$.

Aqui se encontra uma das referências centrais desta pesquisa, por tratar diretamente do objeto de investigação aqui discutido, a tradução da educação como um direito humano fundamental em uma lei recente sobre educação. Com a leitura deste documento, é possível chegar a algumas importantes conclusões relacionadas à situação brasileira quanto à consolidação e o tratamento destinado à educação.

A maneira como a educação é vista no Uruguai é bastante peculiar, por demonstrar claramente a caracterização deste direito, sem dar margem a qualquer tipo de dúvida no momento de seu reconhecimento e aplicação no caso concreto.

No Uruguai, os princípios da educação estão dispostos na própria lei ordinária, porém, no Brasil, os princípios constam do texto constitucional, sendo que as leis ordinárias se limitam a regulamentar as situações fáticas para a concretização daquele

306. Promover a equidade nas condições de acesso, permanência e êxito escolar do aluno no ensino fundamental, por meio da ampliação de programas de transferência direta de renda vinculada à educação (bolsa-escola) e de aceleração da aprendizagem". (BITTAR; ALMEIDA, 2010, p. 72)..

37 "Artículo $1^{\circ}$ (De la educación como derecho humano fundamental). - Declárase de interés general la promoción del goce y el efectivo ejercicio del derecho a la educación, como un derecho humano fundamental. El Estado garantizará y promoverá una educación de calidad para todos sus habitantes, a lo largo de toda la vida, facilitando la continuidad educativa". (URUGUAI, 2008). 
direito, principalmente por se tratar de um direito social, cuja natureza é de norma programática (que depende de complementação trazida por lei ordinária).

No caso brasileiro, apesar dos princípios para a interpretação do direito à educação estarem estampados na Constituição Federal, existe até hoje grandes dificuldades na aplicação deste direito por parte de seus operadores, devido à incorreta interpretação da Carta Magna, cuja hermenêutica deve ser considerada de maneira sistemática.

Tanto em nossa Constituição Federal como em nossas leis ordinárias - que devem ser interpretadas à luz da Carta Magna e todos estes em conjunto com o ordenamento internacional - não há este lugar claro definido para a educação como um direito humano. Ela assim deve ser considerada pela interpretação que se deve fazer do texto constitucional, que considera a educação como um direito fundamental ${ }^{38}$.

Curioso é notar, no entanto, que uma pesquisa de 2008, baseada na opinião pública sobre os direitos humanos, atestou, em um de seus itens, que, dentre os direitos sociais reconhecidos como direitos humanos, o direito à educação ocupou o primeiro lugar, juntamente com o direito à saúde. Pelos dados colhidos na amostra, a porcentagem de indivíduos que assim o considerou foi de $98 \%{ }^{39}$.

Ainda com relação à Lei do Uruguai, esta reconhece a educação como sendo um bem público, cuja finalidade é o desenvolvimento físico, psíquico, ético, intelectual e social de todas as pessoas, sem qualquer forma de discriminação.

Para definir o lugar da educação dentre os direitos humanos, o artigo $4^{\circ}$ da lei uruguaia considera os direitos humanos como referência para o exercício do direito à educação, levando em consideração a Declaração Universal dos Direitos Humanos, a Constituição da República e o conjunto de instrumentos internacionais ratificados por aquele país.

$\mathrm{O}$ artigo $8^{\mathrm{o}^{40}}$ trata da inclusão educativa e da igualdade de oportunidades, sendo dever do Estado assegurar os direitos das minorias no tocante ao direito à educação. Já o

38 Nesse sentido, porém, não resta qualquer dúvida atualmente na doutrina: “Além disso, sob a ótica normativa internacional, está definitivamente superada a concepção de que os direitos sociais, econômicos e culturais não são direitos legais. Os direitos sociais, econômicos e culturais são autênticos e verdadeiros direitos fundamentais". (PIOVESAN, 2009, p. 181).

39 A pergunta que gerou o resultado desta amostra foi a seguinte: "P12a. E destes outros direitos, na sua opinião o ...(direito)... é um direito humano ou não? (se sim) Totalmente ou em parte? (BRASIL, 2010, p. 257).

40 "Artículo 8”: (De la diversidad e inclusión educativa) - El Estado asegurará los derechos de aquellos colectivos minoritarios o en especial situación de vulnerabilidad, con el fin de asegurar la igualdad de oportunidades en el pleno ejercicio del derecho a la educación y su efectiva inclusión social. 
artigo $9^{\circ}$ traz uma ferramenta imprescindível para que os indivíduos se tornem cidadãos, qual seja, a participação no processo educativo, tratada por essa lei como um princípio fundamental da educação, pois visa a formação crítica do saber e a autonomia das pessoas, buscando a erradicação da discriminação e a construção de uma sociedade formada por indivíduos solidários.

Quanto à política educativa nacional, disposta a partir do capítulo III da Lei $\mathrm{n}^{\circ}$ 18437/08, esta possui como principal objetivo que todos os habitantes do País tenham um ensino de qualidade, por toda a vida e em todo lugar daquele território, através de ações educativas desenvolvidas e promovidas pelo Estado, tanto de caráter formal como não formal. Ao mesmo tempo, as outras políticas sociais deverão favorecer o cumprimento dos objetivos da política educacional.

Por essa razão, o sistema educativo uruguaio se propõe a garantir o livre acesso de todos os cidadãos a educação. Isso significa que desde o nível 4 da educação inicial até o $3^{\circ}$ ano da educação média, todos os cidadãos (meninos e meninas) residentes no território nacional devem frequentar obrigatoriamente os seguintes níveis de educação formal: níveis 4 e 5 de educação inicial, do $1^{\circ}$ ao $6^{\circ}$ ano da educação primária e do $1^{\circ}$ ao $3^{\circ}$ ano da educação média básica. Essa obrigatoriedade foi ampliada a um total de 14 anos de escolarização em decorrência da inclusão da educação média superior ${ }^{41}$.

O sistema nacional de educação do Uruguai é definido, então, como um conjunto de propostas educativas integradas e articuladas para todos os habitantes do país, ao longo de toda a vida, constituído pela educação formal e não formal, assim como pela educação na primeira infância ${ }^{42}$.

O Uruguai foi o primeiro país das Américas a ter uma educação primária universal, gratuita e obrigatória, influenciado pelo presidente José Pedro Varela (1875-1876). Como resultado, tem-se que uma das maiores conquistas na esfera educacional é que o país

Para el efectivo cumplimiento del derecho a la educación, las propuestas educativas respetarán las capacidades diferentes y las características individuales de los educandos, de forma de alcanzar El pleno desarrollo de sus potencialidades". (URUGUAI, 2008).

41 "El sistema educativo uruguayo se propone garantizar el libre acceso de todos los ciudadanos a la educación. [...] Es decir que, desde el nivel 4 de educación inicial, hasta el $3^{\circ}$ año de educación media, todos los ciudadanos, niños y niñas residentes en el territorio nacional, deben transitar obligatoriamente los siguientes niveles de educación formal: niveles 4 y 5 de Educación Inicial, Educación Primaria (de $1^{\circ}$ a $6^{\circ}$ año) y Educación Media Básica (de $1^{\circ}$ a $3^{\circ}$ año). Esta obligatoriedad ya ha sido ampliada a 14 años de escolarización mediante la incorporación de la Educación Media Superior”. (URUGUAY, 2009, p. 27, tradução livre).

42 "El Sistema Nacional de Educación es definido como un conjunto de propuestas educativas integradas y articuladas para todos los habitantes del país, a lo largo de toda la vida, conformado por la educación formal y no formal, así como por la educación en la primera infância”. (URUGUAY, 2009, p. 27, tradução livre). 
possui um alto índice de alfabetização, atingindo uma marca de 98\% de alfabetismo, segundo pesquisa realizada em 2003 pelo The World Factbook (CENTRAL INTELLIGENCE AGENCY, 2011).

Esse índice fez com que o Uruguai atingisse a marca de maior índice de alfabetização da América Latina, sendo que o alfabetismo entre as mulheres possui um índice um pouco mais elevado com relação aos homens (98,4\% para as mulheres e 97,6\% para os homens) $)^{43}$.

Já o artigo $16^{44}$, em especial, trata de uma questão bastante enfrentada na realidade brasileira no que diz respeito à educação, que é a barreira do acesso e da permanência no sistema escolar. Na lei uruguaia, é o princípio da gratuidade o responsável por assegurar o cumprimento efetivo do direito à educação e da universalização do acesso e da permanência dos indivíduos naquele sistema.

Quanto ao financiamento, o artigo $19^{45}$ traz a previsão de que os recursos necessários para assegurar o direito à educação e o cumprimento do conteúdo previsto na referida lei devem ser de responsabilidade do Estado.

Os demais capítulos da lei trazem questões administrativas do sistema educacional uruguaio, instituindo como deverá ser cada tipo de educação, de acordo com a faixa etária, modalidade de ensino, dentre outros.

Para garantir a correta aplicação desta lei e de seus princípios fundamentais ali contidos, o artigo $120^{46}$ considera prioridade o interesse do educando, devendo seus direitos serem reconhecidos e respeitados pelo simples fato dele ostentar a qualidade de pessoa humana e, portanto, merecedora de respeito à sua dignidade.

Portanto, percebe-se um maior avanço da legislação uruguaia em relação à brasileira, por reconhecer e tratar a educação como um direito humano, interpretando-o à luz dos princípios de direitos humanos e, desta forma, gerando resultados concretos, de acordo com os dados aqui apresentados, que garantem a sua universalidade.

43 Estes dados são confirmados no Informe sobre Desenvolvimento Humano de 2005, realizado pelo Programa das Nações Unidas para o Desenvolvimento, no qual o Uruguai mantém sua posição de líder da América Latina em relação a alfabetização, com 97,7\% da população, seguido pela Argentina (97,2\%) e Cuba (96,9\%).

44 “Artículo 16: (De la gratuidad) - El principio de gratuidad asegurará el cumplimiento efectivo del derecho a la educación y la universalización del acceso y permanencia de las personas en el sistema educativo". (URUGUAY, 2008).

45 “Artículo 19: (De los recursos) - El Estado proveerá los recursos necesarios para asegurar el derecho a la educación y el cumplimiento de lo establecido en la presente ley”. (URUGUAY, 2008).

46 "Artículo 120: (Principio específico de interpretación e integración) - Para la interpretación e integración de la presente ley se deberá tener en cuenta el interés superior del educando, que consiste en el reconocimiento y respeto de los derechos inherentes a su calidad de persona humana. En consecuencia, este principio no se podrá invocar para menoscabo de tales derechos". (URUGUAY, 2008). 
Ainda com relação ao caso brasileiro, a nova proposta de trabalho em eixos, advinda do PNDH-III, revela que o Ministério da Educação possui incumbência conjunta com os outros ministérios, dentre os mais variados assuntos de direitos humanos ali existentes.

O Programa Nacional de Direitos Humanos também instituiu a elaboração de Planos Estaduais e Municipais de Direitos Humanos, a fim de propor ações governamentais ali previstas, bem como propor novas medidas para proteção dos direitos humanos, de acordo com as peculiaridades de cada Estado, por exemplo.

O Programa de Direitos Humanos do Estado de São Paulo foi instituído pelo Decreto n. ${ }^{\circ}$ 42.209, de 15 de setembro de 1997, do Governador Mário Covas. Assim como o PNDH, os direitos sociais ficaram em segundo plano, valorizando-se, em patamar mais elevado, os direitos civis.

A educação, em especial, corresponde a um item dentro do tópico intitulado: "Direitos econômicos, sociais, culturais e ambientais". Ali, existem oito subitens que tratam da educação de modo específico, visando um ensino público de melhor qualidade, e procurando diminuir a evasão escolar e garantir o direito de acesso à educação.

Porém, da maneira como são descritas essas metas, há uma contradição com relação à universalidade da garantia da educação para os jovens e adultos, pois para estes, o poder público apenas teria como incumbência a promoção de cursos de alfabetização. Já o acesso ao ensino fundamental e médio, por sua vez, é tido como uma garantia e até mesmo um dever do poder público (GRACIANO, 2005, p. 40).

Neste programa, ainda, a educação aparece dentre os direitos civis e políticos como um instrumento para o alcance de outros fins. E, nesse aspecto, há um ponto de encontro com o Programa Nacional de Direitos Humanos, na medida em que a educação ora aparece como caminho para o alcance da capacitação profissional, ora como forma de se atingir a ressocialização.

Além disso, a educação aparece também no Plano Municipal de Direitos Humanos da Cidade de São Paulo, aprovado durante a primeira Conferência Municipal de Direitos Humanos, nos dias 09 e 10 de dezembro de 1997. Este Plano foi finalizado em março de 1998, exatamente no ano em que a Declaração Universal de Direitos Humanos completou 50 anos (DIREITOS..., 2011).

A iniciativa de sua elaboração coube ao Poder Legislativo, por meio da criação da Comissão de Direitos Humanos e Cidadania e a instalação do Fórum Municipal de Direitos da Pessoa Humana. 
Uma das grandes diferenças do presente Plano com relação aos outros anteriormente mencionados diz respeito à hierarquia de valores dos direitos civis $\mathrm{e}$ políticos, comparados aos direitos econômicos, sociais e culturais.

Neste plano, os direitos econômicos, sociais e culturais são condições essenciais de existência para os direitos civis e políticos, a saber: "assegura-se, então, o princípio da indivisibilidade dos direitos humanos. É impossível a realização dos direitos civis e políticos sem o acesso aos direitos econômicos, sociais e culturais". (DIREITOS..., 2011).

A educação está presente neste documento no tópico referente às propostas para a garantia dos direitos humanos de "Gays, Lésbicas e Travestis", a fim de se criar programas específicos para a garantia da livre orientação sexual (GRACIANO, 2005, p. 43).

Da mesma forma, a educação aparece no item relativo à "Terceira Idade" e também no tópico referente aos "Prisioneiros e Prisioneiras". No entanto, estas propostas para grupos específicos da população acabaram permitindo com que apenas "Crianças e adolescentes" e "Terceira Idade" tivessem direito a políticas educacionais reconhecidas como direito humano.

Isto porque, ao prever ações para os outros grupos, o Plano prevê ações de formação em direitos humanos, tratando dos agentes de Estado que lidam com estes, bem como ações visando ao acesso à informação para possibilitar as condições para as pessoas exercerem seus direitos.

Cabe mencionar, porém, que nesse Plano, ainda, não há qualquer iniciativa para a educação de portadores de necessidades especiais em nenhuma modalidade. Assim também, apesar de prever a universalidade da educação, não há garantias específicas para os jovens e adultos que não tiveram acesso à escolarização na primeira etapa da vida escolar, bem como para a população carcerária em geral.

Percebe-se, portanto, com a análise destes documentos, que o tratamento da educação como um direito humano somente ocorre no caso de grupos específicos. No que se refere às ações, a educação aparece como instrumento de formação para ou em direitos humanos, ou seja, geralmente como forma de garantia para o alcance de outras finalidades (GRACIANO, 2005, p. 44). Isso significa que a universalidade, que é uma das principais características dos direitos humanos, não foi totalmente atendida, apesar de afirmada nesses documentos.

No entanto, no presente momento, existe a expectativa de formulação de outro importante documento que tratará especificamente da educação em nosso município, qual seja, o Plano de Educação da Cidade de São Paulo. Nos debates para a sua construção 
realizados até agora, percebe-se uma maior preocupação na concepção da educação como um direito humano, na medida em que isto fará parte da determinação dos eixos e concepções orientadoras do referido Plano.

As metas a serem estabelecidas neste documento servirão de baliza por durante uma década. Dentre os objetivos pretendidos, de acordo com as palavras do secretário municipal de educação Alexandre Schneider, durante o processo de construção participativa do Plano de Educação da Cidade de São Paulo (SÃO PAULO, 2009, p. 6), estão:

[...] ampliar e qualificar o atendimento da Educação Infantil, acabar com as escolas de terceiro turno, diminuir o número de alunos por sala de aula, valorizar nossos educadores e aumentar o tempo de permanência dos alunos nas escolas. $\mathrm{O}$ Plano traçará novas e mais auspiciosas metas em direção à qualidade de ensino que buscamos.

O Plano de Educação da Cidade de São Paulo ocorrerá em atendimento à Lei n. ${ }^{\circ}$ 10.172/01, que criou o Plano Nacional de Educação, aprovado pelo Congresso Nacional em 2001. Atende também o constante na Lei de Diretrizes e Bases da Educação Nacional (Lei n. ${ }^{\circ}$ 9.394/96), bem como o artigo 214 da Constituição Federal. Logo no início da apresentação do documento relativo ao processo de construção do Plano (SÃO PAULO, 2009, p. 6), constata-se o enquadramento da educação como um direito em si: "Tais políticas devem garantir as condições para a concretização do direito humano à educação de qualidade para todas as pessoas".

Com isso, pretende-se elaborar um Plano com a ampla participação da sociedade civil, que é a maior interessada neste assunto, bem como dos diversos setores do poder público, cuja responsabilidade se atribui visando à efetividade em sua implantação.

Após a convocatória para a construção do plano, realizou-se uma reunião para o seu lançamento oficial, em 15 de agosto de 2008, contando com a participação de diversos agentes da sociedade civil e do poder público.

$\mathrm{O}$ documento que ali se produziu contém um diagnóstico da cidade e de seu atendimento educacional, mapeando-se as redes de ensino na cidade, nos diferentes estágios de instrução.

Um aspecto bastante positivo encontrado nesse esboço de construção do Plano (SÃO PAULO, 2009, p. 19-20) diz respeito à questão metodológica. Para atingir os objetivos ali propostos, desenvolveu-se uma metodologia voltada a gerar um processo participativo, procurando atender a quatro questões-chave: "1) qual a educação que queremos (para a nossa escola, comunidade, região e cidade)?; 2) o que vivemos: qual a 
educação que temos hoje (diagnóstico)?; 3) quais as perguntas sobre o atendimento educacional que gostaríamos de fazer ao poder público de nossa cidade?; 4) quais as principais propostas que temos para alcançar uma educação de qualidade em nossa escola, comunidade, região e/ou cidade?"

Além disso, este Plano possuirá como eixo orientador, em seu item 3.1.1, a educação como direito humano e, nesse sentido,

\begin{abstract}
[...] pressupõe a construção de relações de respeito à diversidade, entendida como "a construção histórica, cultural e social da diferença existente nos seres humanos, e como tal deve ser respeitada e valorizada para desmistificar a idéia de inferioridade que paira sobre a diferença humana. O desafio está em desenvolver uma postura de não hierarquização das diferenças e entender que nenhum grupo humano e social é melhor do que o outro. Na realidade, todos são diferentes e devem ser tratados com justiça social e equidade". (BRASIL, 2008, p. 32-42).
\end{abstract}

Outro eixo constante neste esboço do Plano (SÃO PAULO, 2009, p. 22-23) considera a educação como fator de inclusão e de desenvolvimento social, estruturando as políticas educacionais de forma a contribuir na discussão da relação entre formação, diversidade, inclusão e qualidade social da educação, promovendo reflexões e ações específicas para combater o racismo, o sexismo, a homofobia e a intolerância, bem como promover a igualdade de gênero, a diversidade regional e cultural, dentre outros.

Existe também a orientação da educação no sentido de se obter uma cultura de paz, tanto no âmbito coletivo como no âmbito individual. Nesse caso, de acordo com o que se pretende no futuro Plano (SÃO PAULO, 2009, p. 23), tanto a educação como a instituição escolar devem assumir essa função essencial visando à formação de cidadãos e agentes de transformação social.

Note-se, por fim, que, ao tratar da educação como direito humano, o Plano pretende não se resumir apenas aos grupos específicos, mas a todas as crianças, adolescentes, jovens, adultos e idosos. Todos estes, de acordo com o item 3.2.4 do projeto do Plano, formam uma das concepções orientadoras do Plano, qual seja, a concepção de educando.

Resta saber se, no momento de sua implementação, o Plano irá atender efetivamente a todos os sujeitos de direitos educacionais, e se as políticas públicas serão concretizadas. Ainda assim, em caso positivo, será necessária a realização de um novo balanço, a fim de se constatar se tais ações educativas atenderão ou não aos quesitos da universalidade e indivisibilidade dos direitos humanos, ou se, apesar de sua formulação no projeto, tais políticas terão o caráter de uma educação voltada para os direitos humanos ou 
uma educação específica em direitos humanos, ignorando-se a própria educação como um direito humano em si e principal finalidade para se atingir a cidadania e a consolidação de nossa democracia.

No entanto, é importante ressaltar que a plena efetivação do direito à educação também deve se dar através da atuação conjunta dos diversos setores da sociedade civil, como se pode citar, por exemplo, no trabalho da organização sem fins lucrativos denominada "Ação Educativa".

No próprio site desta organização do terceiro setor, pode-se encontrar uma "cartilha" completa contendo o passo a passo para que todo e qualquer cidadão saiba como agir em caso de violação ao direito à educação ${ }^{47}$. Há também diversos links de acesso direto aos principais documentos nacionais e internacionais que versam sobre o assunto, objetivando orientar todas as pessoas, e não somente os operadores do direito ou demais técnicos em educação.

Nesse ambiente virtual, qualquer pessoa poderá, também, entender como se recorre à justiça, bem como poderá encontrar endereços e dicas úteis para assessoria jurídica, incluindo-se desde modelos de petição e explicações de quando é necessária a presença de advogado, até quando ela também é dispensável.

Além disso, há explicações sobre o funcionamento dos diversos órgãos que são direta ou indiretamente responsáveis pela aplicação deste direito, desde as principais organizações da sociedade civil até os respectivos órgãos públicos. Há também excelentes fontes de consulta para atualização e pesquisa sobre o tema, difundindo-se a ideia e a recente discussão acerca da educação como direito humano.

Um dos programas desenvolvidos pela Ação Educativa chama-se "Ação na Justiça”, cuja compreensão acerca da exigibilidade do direito à educação é bastante ampla, envolvendo as três dimensões essenciais para se fazer valer este direito: a social, a política e a jurídica. A primeira delas diz respeito à própria pressão social a ser exercida por um conjunto de pessoas, podendo ser de diferentes formas, tais como denúncias aos meios de comunicação de massa, protestos, atos públicos, abaixo-assinados, cartas endereçadas aos órgãos públicos, etc. A segunda forma diz respeito a ações de mobilização social em favor de legislações e políticas públicas previstas nas leis internas e nos tratados internacionais.

47 Nesse sentido, existe também uma cartilha que constitui outro importante material de pesquisa e instrumento de apoio a todo e qualquer cidadão que pretende fazer valer o direito humano à educação, podendo ser encontrado no endereço eletrônico da Plataforma Brasileira de Direitos Humanos Econômicos, Sociais, Culturais e Ambientais. Disponível em:

<http://www.dhescbrasil.org.br/index.php?option=com_docman\&Itemid=125>. Acesso em: 12 out. 2010. 
Para tanto, existem diversos mecanismos de participação popular ativa, tais como os conselhos de educação. Por último, a outra forma diz respeito à exigibilidade jurídica, pleiteando-se este direito através do sistema judiciário.

É importante ressaltar que o principal objetivo deste Programa é a própria difusão do conceito de educação como direito humano, acreditando-se que, pelo simples fato de ser um direito, já é passível de ser exigido pelas autoridades que se responsabilizaram em garanti-lo, independentemente das situações econômicas ou mercadológicas. Acredita-se, também, que o fato de se reagir a circunstâncias onde houve violação a um direito educativo (tanto no que diz respeito ao seu acesso como à sua qualidade), já constitui um meio idôneo a se ampliar a efetividade deste direito.

Nesse sentido, cita-se o trabalho efetuado pelas equipes da Relatoria Nacional para o Direito Humano à Educação que se dedicaram, no ano de 2007, à investigação de denúncias de desrespeito ao direito à educação de crianças, jovens e adultos das instituições de ensino do Complexo do Alemão, na zona norte do Rio de Janeiro. Isso se deveu ao fato de haver inúmeros confrontos entre a Polícia Militar e os criminosos daquela região, ocasionando sucessivas interrupções do trabalho de creches e escolas. E como forma de pressão a uma solução para estes abusos, a ideia desenvolvida pelos defensores desse direito foi a de apresentar um relatório sobre a situação para a Organização dos Estados Americanos ${ }^{48}$.

Se, por um lado, o aumento do número de denúncias a violações de direitos humanos, em especial o direito à educação, de casos brasileiros perante as Organizações Internacionais representa um motivo de grande preocupação para o Estado brasileiro, por outro, constitui o avanço na exploração de uma forma idônea de se exigir um direito garantido e consagrado em nossas leis.

Espera-se, com isso, que tal forma de pressão aos organismos internacionais possa fazer frente ao cumprimento de leis internas, colocando o nosso País em evidência perante os demais, de modo a contribuir para a diminuição de casos semelhantes.

48 Conforme notícia veiculada na Internet: Defensores do direito à educação investigam o Complexo do Alemão (FOLHA ON LINE, 2010). 


\section{A EDUCAÇÃO NOS RELATÓRIOS BRASILEIROS SOBRE DIREITOS HUMANOS ECONÔMICOS, SOCIAIS, CULTURAIS E AMBIENTAIS}

O presente tópico visa a discutir o trabalho das relatorias nacionais dos Direitos Humanos Econômicos, Sociais, Culturais e Ambientais (DhESCA), cuja denominação passou a incluir os direitos ambientais nesse rol de direitos. Para atender à delimitação do objeto desta pesquisa, optou-se pelo detalhamento da situação da educação, tal como descrita nos relatórios disponíveis da Plataforma Brasileira DhESCA. Neste item serão apresentados alguns resultados gerais do relatório de 2003 e, após, as observações específicas realizadas na missão sobre educação da Relatoria em Fortaleza, Ceará. Antes disso, far-se-á a apresentação do histórico da constituição da referida Plataforma.

A justificativa desta escolha reside no fato de que esses documentos, além de apresentarem dados relevantes para a análise da situação da educação brasileira, constituem um importante ponto de partida para a efetivação deste direito no plano concreto. E também representam um grande paradigma em nossa história, devido à implementação de uma nova relação entre o governo e a sociedade civil, resultando na abertura a um produtivo diálogo.

Inicialmente, as organizações de diversos setores da sociedade civil e redes nacionais que compõem a Plataforma Brasileira de Direitos Humanos Econômicos, Sociais, Culturais e Ambientais ${ }^{49}$ espelharam-se no histórico vivenciado pelos Relatores

49 A Plataforma Dhesca Brasil é uma articulação nacional de 36 movimentos e organizações da sociedade civil que desenvolve ações de promoção, defesa e reparação dos Direitos Humanos Econômicos, Sociais, Culturais e Ambientais (doravante abreviados em Dhesca), visando o fortalecimento da cidadania e a radicalização da democracia.

As organizações filiadas à Plataforma DhESCA Brasil são: Associação Brasileira de Nutrição e Direitos Humanos (Abrandh); Ação Educativa - Assessoria, Pesquisa e Informação; Ações em Gênero, Cidadania e Desenvolvimento (Agende); Articulação de Mulheres Brasileiras (AMB); Articulação de Organizações de Mulheres Negras Brasileiras (AMNB); Centro de Defesa da Vida Herbert de Souza (CDVHS); Centro de Educação e Assessoramento Popular (Ceap); Centro Dom Helder Câmara de Estudos e Ação Social (Cendhec); Centro Feminista de Estudos e Assessoria (Cfemea); Centro Indigenista Missionário (Cimi); Comissão de Justiça e Paz de São Paulo (CJP-SP); Conectas Direitos Humanos; Conselho Nacional de Igrejas Cristãs (Conic); Comissão Pastoral da Terra (CPT); Criola Organização de Mulheres Negras; Dom da Terra; Fala Preta! Organização de Mulheres Negras; Federação dos Órgãos de Assistência Social e Educacional (Fase Nacional); Rede de Informação e Ação pelo Direito Humano a se Alimentar (Fian Brasil); Gabinete de Assessoria Jurídica às Organizações Populares (Gajop); Geledés Instituto da Mulher Negra; Instituto Brasileiro de Análises Sociais e Econômicas (Ibase); Instituto de Estudos Socioeconômicos (Inesc); Instituto Pólis - Instituto de Estudos, Formação e Assessoria em Políticas Sociais; Justiça Global; Movimento Atingidos por Barragens (MAB); Movimento de Educação de Base (MEB); Movimento das Mulheres Camponesas (MMC); Movimento Nacional de Direitos Humanos 
Especiais das Nações Unidas para analisar situações de violação aos direitos humanos. (TERRA DE DIREITOS, 2005).

Essas organizações e redes nacionais, contando com a ajuda do programa de Voluntários das Nações Unidas ${ }^{50}$, nomearam seis relatores nacionais ${ }^{51}$ para investigarem as

(MNDH); Movimento Nacional de Meninos e Meninas Rua (MNMMR); Movimento dos Trabalhadores Rurais Sem Terra (MST); Rede Feminista de Saúde, Direitos Sexuais e Reprodutivos (Rede Saúde); Rede Social de Justiça e Direitos Humanos (Rede Social); Sociedade Paraense de Defesa dos Direitos Humanos (SDDH); Sociedade Maranhense de Direitos Humanos (SMDH) e Terra de Direitos. (RELATORIAS DE DIREITOS HUMANOS, 2011).

A Plataforma Brasileira de Direitos Humanos Econômicos, Sociais, Culturais e Ambientais - DhESCA Brasil - constitui-se como seção nacional da Plataforma Interamericana de Direitos Humanos, Democracia e Desenvolvimento (PIDHDD), sendo uma rede de articulação de entidades que atuam em direitos humanos econômicos, sociais e culturais. Está aberta à adesão. Fundada em novembro do ano 2000 por um conjunto de instituições que lidam com a temática dos direitos humanos em suas mais diversas vertentes, a DhESCA Brasil propõe-se a estabelecer um amplo debate sobre a indivisibilidade e universalidade dos direitos humanos. Assim, o acréscimo da palavra "humanos" à sigla DESC (direitos econômicos, sociais e culturais) é o mais visível símbolo do compromisso político da Plataforma com a luta por todos os direitos de todos os seres humanos.

São objetivos da Plataforma DhESCA Brasil: 1. Difundir os direitos humanos econômicos, sociais e culturais, como direitos universais e indivisíveis, sem diferenciação geracional entre estes e os direitos civis e políticos; 2. Desenvolver uma ampla cultura de direitos a partir da noção de que todos e todas são sujeitos de direitos; 3. Buscar consenso entre as várias redes, organizações e movimentos, visando à integração dos vários olhares destes grupos em torno de uma perspectiva de luta por direitos.

A Plataforma DhESCA Brasil possui as seguintes esferas de atuação: 1. Atividades de lobbying e articulação em âmbito internacional em torno da validação de direitos humanos; 2. Realização de campanhas anuais no Brasil em torno de temas associados à temática dos DhESCA; 3. Monitoramento da implementação dos direitos humanos no Brasil através do acompanhamento do processo de revisão e aplicação dos direitos econômicos, sociais e culturais no Plano Nacional de Direitos Humanos e; criação da figura dos relatores nacionais com a finalidade de desenvolverem processos de consulta ao nível nacional sobre a situação destes direitos no Brasil; 4. Formação em direitos humanos; 5. Seleção de "casos de exigibilidade" ao nível jurídico nacional e internacional (Nações Unidas e Organização dos Estados Americanos); 6. Publicações especializadas sobre direitos humanos. A Plataforma é Coordenada pela representação das seguintes entidades: Movimento Nacional de Direitos Humanos - MNDH; Comissão Justiça e Paz de São Paulo - CJP-SP; Rede de Informação e Ação pelo Direito a se Alimentar - Fian; Gabinete de Assessoria Jurídica às Organizações Populares - Gajop; Centro de Justiça Global; Federação de Órgãos para Assistência Social e Educacional - Fase. (ASSOCIAÇÃO DE COMBATE AOS POLUENTES, 2011, p. 4-5).

50 Desde 1971, o programa dos Voluntários das Nações Unidas (VNU), administrado pelo Pnud, envia especialistas e voluntários de campo profissionalmente experientes para trabalhar em projetos de cooperação nacional e internacional de desenvolvimento. Além da cooperação técnica, o núcleo do trabalho concentra-se cada vez mais em áreas de apoio humanitário, de preservação e respeito dos direitos humanos e da preparação e observação de eleições. Outra tarefa muito importante do Programa é a promoção do voluntariado entre os cidadãos para ampliar o seu engajamento voluntário em diversas áreas.

Todos os anos, em torno de 7.000 mulheres e homens qualificados e com grande experiência profissional de mais de 170 nacionalidades servem como voluntários da ONU em mais de 140 países. 60\% deles atuam em países que não são os seus próprios e são recrutados por suas especialidades profissionais em uma das mais de 100 categorias profissionais disponíveis. 40\% dos voluntários da ONU servem como voluntários nacionais nos seus próprios países e apoiam as iniciativas de construção de capacidades locais além de facilitar o estabelecimento de redes locais e de troca de informações.

O programa dos Voluntários das Nações Unidas no Brasil foi criado em 1998. É um programa em crescimento, de cooperação com projetos de parceiros diferentes em todo o Brasil para os quais necessita de pessoas qualificadas que cumprem serviços voluntários nesses projetos de desenvolvimento. No Brasil, milhões de pessoas já estão engajadas como voluntários em clubes, ONGs, igrejas, escolas etc. e milhares de voluntários participam em projetos sociais de empresas privadas com o objetivo de melhorar as condições de vida em comunidades carentes, proteger o meio ambiente ou contribuir para outras 
ofensas aos direitos à alimentação, água e terra rural; ao meio ambiente; à saúde; à moradia adequada e à terra urbana; à educação, bem como o direito ao trabalho, surgindo, assim, as relatorias nacionais dos DhESCA.

O processo de seleção dos relatores nacionais ocorreu por meio de um edital público, divulgado entre redes, fóruns, organizações e diversos setores da sociedade civil, com o objetivo de selecionar especialistas em direitos humanos que atuassem nas temáticas definidas em cada período (PLATAFORMA BRASILEIRA DE DIREITOS HUMANOS ECONÔMICOS, SOCIAIS, CULTURAIS E AMBIENTAIS, 2009a, p. 19).

Nesse edital foram definidos os eixos prioritários que deveriam ser atribuídos a cada relatoria, apontados pela própria Plataforma DhESCA como assuntos fundamentais para a construção do referido mandato. Também se encontram no edital as perspectivas que devem balizar o trabalho de todos os relatores, tais como as desigualdades sociais e a dimensão dessas desigualdades nas questões racial e de gênero. Para isso, existe um termo de mandato que contém elementos comuns e também específicos de cada área temática, elaborados com a participação dessas organizações da sociedade civil.

A partir desses requisitos mencionados no edital, o processo de seleção dos relatores foi feito por intermédio de um Conselho de Seleção independente, composto por

atividades específicas. Nesse sentido, o programa VNU procura também parcerias com as empresas privadas, com universidades e fundações, pois acreditamos que uma maior participação desses atores sociais na cooperação de desenvolvimento pode trazer vantagens a todas as partes envolvidas. (ORGANIZAÇÃO DAS NAÇÕES UNIDAS, 2011).

51 As Relatoras e os Relatores são especialistas em suas áreas temáticas. São escolhidos para o mandato de dois anos, tendo por base alguns critérios: conhecimento e experiência profissional no campo dos direitos humanos; reconhecimento público do compromisso com a promoção dos direitos; legitimidade perante fóruns, redes e organizações da sociedade civil; autonomia e independência perante os órgãos governamentais.

Os/As relatores/as exercem sua função de forma voluntária, sem remuneração profissional. Em geral, são ligados às redes da Plataforma que lhe dão suporte e sugestões de demandas. Têm por atribuição: monitorar a situação dos direitos humanos de forma exemplar, ou seja, conhecer profundamente os problemas relacionados ao seu mandato; articular amplos setores sociais em busca da cooperação e soluções para os problemas verificados; e apresentar soluções viáveis por meio de políticas públicas e de novas leis que objetivam melhorar a qualidade de vida da população brasileira.

Por exercerem voluntariamente seus mandatos, as Relatorias contam com o suporte operacional da secretaria executiva e, principalmente das assessorias. Cada Relatoria possui uma assessoria, também especialista no tema específico e referenciada nas redes e organizações de apoio. As assessorias são figuras essenciais no preparo, execução e sistematização das atividades das Relatorias, dando-lhes todo o suporte necessário. (RELATORIAS DE DIREITOS HUMANOS, 2011).

Os assessores das Relatorias são pessoas que devem ter um conhecimento básico e alguma experiência sobre os direitos das Relatorias. Eles podem ser indicados pelos relatores e pelas organizações que integram as redes e fóruns que apoiam o desenvolvimento do Projeto Relatores Nacionais em DhESC. O processo de escolha é feito também com base nos critérios do Programa Voluntários das Nações Unidas que é um dos parceiros do projeto. Os assessores são selecionados através deste programa de forma conjunta com os Relatores e a Coordenação do projeto e são considerados membros do UNV. Como voluntários das Nações Unidas, recebem uma bolsa auxílio mensal para exercerem as funções da assessoria. (RELATORIAS NACIONAIS EM DIREITOS HUMANOS ECONÔMICOS, SOCIAIS E CULTURAIS, 2004, p. 9). 
representantes das organizações da coordenação executiva da rede e de órgãos públicos e agências da ONU (PLATAFORMA BRASILEIRA DE DIREITOS HUMANOS ECONÔMICOS, SOCIAIS, CULTURAIS E AMBIENTAIS, 2009a, p. 20).

O primeiro grupo de relatores nacionais foi nomeado em outubro de 2002, para um mandato de dois anos, enquanto que o segundo grupo de relatores foi designado no início de 2005, pelo Conselho de Escolha dos Relatores Nacionais em Direitos Humanos Econômicos, Sociais e Culturais (DhESC), constituído por nove organizações da sociedade civil, quatro organismos do Estado Brasileiro e outras seis entidades ligadas às Nações Unidas $^{52}$. Especificamente para a produção do relatório do Complexo do Alemão em 2007, a Relatoria Nacional para o Direito Humano à Educação, vinculada à Plataforma DhESCA, constituía-se pelo trabalho conjunto entre quarenta e três organizações e redes nacionais de direitos humanos (RELATORIA NACIONAL PARA O DIREITO HUMANO À EDUCAÇÃO, 2007).

A grande missão atribuída aos relatores nacionais é de avaliar a efetividade desses direitos em uma determinada sociedade, apresentando projetos para a solução dos problemas.

Com isso, procura-se incentivar o Estado brasileiro na adoção de um patamar mínimo de respeito aos direitos humanos econômicos, sociais e culturais, e também ambientais, levando-se em conta os compromissos assumidos pelo País internamente, traduzidos, principalmente, pela Constituição brasileira e o Programa Nacional de Direitos Humanos, bem como pelos tratados internacionais de direitos humanos ratificados pelo País.

O ponto de partida de uma determinada missão ocorre com a denúncia de uma situação de violação de direitos humanos. A partir desta revelação, a missão se desloca até o local, passando a elaborar relatórios a respeito daquela ocorrência.

A metodologia de trabalho dos relatores, após o recebimento da denúncia urgente, compreende, além da visita ao local da violação relatada, reuniões periódicas para a troca de ideias e experiências entre todos os relatores e assessores e a prestação de contas às autoridades públicas em geral por meio de relatórios anuais específicos para esse fim.

52 Especificando cada uma das nove organizações da sociedade, tem-se: a Federação de Órgãos para a Assistência Social e Educacional - Fase; Movimento Nacional de Direitos Humanos - MNDH; Gabinete de Assessoria Jurídica às Organizações Populares - Gajop; Centro de Justiça Global; Agende; FianBrasil; Criola; Terra de Direitos e Sociedade Paraense de Direitos Humanos. Os quatro organismos do Estado Brasileiro são constituídos por: Comissão de Direitos Humanos da Câmara Federal, Departamento de Direitos Humanos do Ministério das Relações Exteriores, Procuradoria Federal dos Direitos do Cidadão e Secretaria Especial de Direitos Humanos. Já as seis entidades vinculadas às Nações Unidas são: Unicef, Unesco, UNV, Pnud, FAO e OIT. (TERRA DE DIREITOS, 2005). 
No âmbito interno, os relatórios anuais são apresentados nas Conferências Nacionais de Direitos Humanos da Câmara Federal, no Conselho de Defesa dos Direitos da Pessoa Humana, e nos ambientes onde se discutam os temas das relatorias. Já no âmbito internacional, esses relatórios podem ser apresentados perante a Comissão de Direitos Humanos da ONU e a Comissão de Direitos Humanos da OEA.

O Observatório da Educação, grupo organizado especificamente para a elaboração do relatório DESC de educação, no marco da organização não-governamental Ação Educativa, classifica a organização de uma missão da relatoria em cinco fases:

a) qualificação da denúncia: período em que ocorre o levantamento de informações sobre a problemática a partir da denúncia do caso de violação do direito humano à educação;

b) realização da missão: momento que abrange a pesquisa de campo, ou seja, as visitas às comunidades atingidas, entrevistas com os alunos, seus familiares, os educadores e os dirigentes escolares, reuniões com autoridades locais, realização de audiência pública com as populações atingidas e as autoridades para a discussão da problemática em questão e a elaboração de um plano de trabalho com vistas a enfrentá-la;

c) elaboração do relatório: a equipe da relatoria elabora um texto contendo a denúncia, as entrevistas realizadas e o plano elaborado para a solução do problema;

d) entrega do relatório às autoridades e divulgação nacional e internacional: após sua divulgação pela imprensa nacional e internacional, o relatório é entregue às autoridades nos âmbitos federal, estadual e municipal, e algumas instâncias internacionais para providências;

e) seguimento: após determinado período preestabelecido, é realizada uma missão para o acompanhamento da efetivação do plano de ação. (OBSERVATÓRIO DA EDUCAÇÃO, 2009).

O intuito da elaboração desses relatórios é disponibilizar o seu uso para que as organizações da sociedade civil os implementem na defesa e promoção dos direitos humanos na prática. Para tanto, conforme mencionado anteriormente devem conter parâmetros essenciais de análise definidos previamente para a realização de um trabalho de campo direcionado, tais como as perspectivas étnico-racial, de gênero e regional dos problemas do País, além de serem fiéis às informações e fontes consultadas.

Com isso, o objetivo principal da Plataforma DhESCA é não só primar pela qualidade dos relatórios das missões, mas estimular a participação da sociedade civil na elaboração de políticas públicas e construção de uma estrutura que garanta a inclusão dos 
indivíduos nos processos coletivos, por meio do amplo debate da sociedade civil, obtendo a participação de todos na defesa da garantia universal de direitos.

Segundo o informe 2009/2011 da Plataforma DhESCA (RELATORIAS DE DIREITOS HUMANOS, 2011), as relatorias de direitos humanos, quando estão em suas missões, não atuam sozinhas, contando também com o incentivo de organizações locais, redes temáticas, entidades filiadas à própria Plataforma e pessoas da sociedade civil. Este projeto como um todo traz a coleta de dados significativos de direitos humanos, permitindo aprimorar os instrumentos jurídicos e administrativos existentes e apontar as recorrentes violações de direitos humanos no Brasil, servindo como norte para a criação de políticas públicas no combate a essas violações.

Conforme destacado naquele informe, esta sistemática das relatorias de direitos humanos brasileiras já foi adotada pela Argentina e, aos poucos, começa a se difundir por outros países, como, por exemplo, a Colômbia ${ }^{53}$.

Passaremos a apresentar algumas informações gerais e ainda iniciais sobre os trabalhos das relatorias. Posteriormente, faremos um apanhado mais detalhado dos trabalhos e seus resultados.

Primeiramente, vale ressaltar que a Plataforma DhESCA realiza periodicamente reuniões com os relatores e assessores para planejar as respectivas missões. Durante esses encontros são discutidos os procedimentos para a realização das missões e os temas estratégicos que serão abordados pelas Relatorias (PLATAFORMA BRASILEIRA DE DIREITOS HUMANOS ECONÔMICOS, SOCIAIS, CULTURAIS E AMBIENTAIS, 2009b).

No período compreendido entre os anos de 2002 a 2004, a Relatoria Nacional para o Direito Humano à Educação teve seu primeiro mandato representado pelo Relator Nacional Sérgio Haddad e a Assessora Nacional Mariângela Graciano.

53 Na Argentina, citam-se como exemplos os relatórios anuais do Centro de Estudos Legais e Sociais (CELS) sobre a situação dos direitos humanos naquele país, como, por exemplo, o de 2002-2003, que abordou uma amplitude de temas, que vão desde os crimes cometidos durante a ditadura militar que governou o país na década de 80 , as transformações no sistema judicial, a insegurança policial e outras formas de violência institucional. Este relatório tratou também a situação da violência e da aglomeração nas prisões e delegacias, as agressões perpetradas contra militantes sociais e as respostas do Estado frente a crise social e o colapso do sistema de saúde (ARGENTINA..., 2003). Além disso, merecem também destaque as informações apresentadas pelo relatório "Violação dos Direitos Humanos das Pessoas Lésbicas, Bissexuais, Travestis, Transgênero, Transexuais e Intersexual (LBTTTI) na Região Noroeste da Argentina (NOA)" na 46 ${ }^{\mathrm{a}}$ Sessão do Comitê da Convenção sobre Eliminação de Todas as Formas de Discriminação contra a Mulher (Cedaw). (UNIVERSIDADE LIVRE FEMINISTA, 2010).

$\mathrm{Na}$ Colômbia, o Relatório de Atividades do CICV (Comitê Internacional da Cruz Vermelha) divulgado em abril de 2011 registrou ao menos 768 casos de violações de direitos humanos registrados em 2010. (OPERA MUNDI, 2011). 
Especificamente no período de janeiro de 2003 a setembro de 2004, a referida Relatoria averiguou violações ao direito humano à educação em missões realizadas aos estados de Alagoas e Amazonas, dando conta dos entraves à efetivação deste direito de maneira universal.

Uma das situações relatadas no estado de Alagoas diz respeito aos desvios das verbas públicas destinadas à educação, corrupção e precária fiscalização e administração dos recursos públicos e violência empregada contra os profissionais da educação em geral.

Outra situação constatada refere-se à observação realizada no Amazonas, em que o direito à educação diferenciada das populações indígenas brasileiras, incluindo o respeito às suas especificidades culturais, apesar de assegurado, é frequentemente violado na prática. (RELATORIAS NACIONAIS EM DIREITOS HUMANOS ECONÔMICOS, SOCIAIS E CULTURAIS, 2004, p. 28).

Entre os anos de 2007 a 2009, a missão da Relatoria dos DhESCA destacou-se por monitorar o acesso à educação nos sistemas prisionais brasileiros. Antes disso, em 2006, pela primeira vez, a Relatoria Nacional para o Direito Humano à Educação tratou o tema “Educação nas Prisões”. Naquele ano, a Relatora Nacional de Educação, Edla Soares, exsecretária municipal de educação de Recife, e sua assessora Ednar Cavalcanti realizaram missão sobre a situação das unidades prisionais femininas de Pernambuco (OBSERVATÓRIO DA EDUCAÇÃO, 2009).

Como repercussão dos trabalhos realizados pela relatoria do direito humano à educação, destaca-se a aprovação das diretrizes nacionais de educação nas prisões, pelo Conselho Nacional de Educação. O texto desse documento traz citações do Relatório da missão 2009 sobre educação nas prisões brasileiras. Tal relatório foi considerado um importante instrumento para a elaboração das normas nacionais sobre educação nas prisões, sendo que suas recomendações foram apresentadas ao Conselho em dezembro de 2009.

No plano de trabalho da Relatoria do Direito Humano à Educação, representado, nos anos de 2008 e 2009, pelo primeiro mandato de Denise Carreira, jornalista e educadora, e sua assessora Suelaine Carneiro, o foco consistiu na questão da educação e segurança pública, cujas principais missões realizadas foram a de monitoramento da situação educacional no Morro do Alemão e o acesso à educação nos sistemas prisionais brasileiros.

Para o segundo mandato de Denise Carreira, nos anos de 2010 e 2011, devido à sua recondução ao cargo de relatora, o principal foco dessas missões tem sido a educação 
quilombola, a intolerância religiosa e o racismo no cotidiano escolar (RELATORIAS DE DIREITOS HUMANOS, 2011).

Para tratar da problemática da intolerância religiosa, os relatores se prestaram a acompanhar de perto a situação vivida em três grandes estados: Rio de Janeiro, Bahia e São Paulo. Estas missões se dispõem a ouvir os depoimentos de líderes religiosos, estudantes, profissionais ligados à educação, pesquisadores e autoridades públicas, como, por exemplo, alguns representantes do Ministério Público e das Secretarias de Educação.

As denúncias abrangem casos de violência física, marcados por socos e até mesmo apedrejamento contra estudantes, demissão ou afastamento de profissionais de educação ligados a religiões de origem africana, ou simplesmente pelo fato de tratarem dos conteúdos dessas religiões em sala de aula, a proibição do ensino da capoeira, a dolorosa omissão diante da discriminação, dentre outras.

De acordo com o Informe 2009/2011 das Relatorias de Direitos Humanos (2011, p. 6), esses relatos revelam que a intolerância está aumentando em virtude do crescimento de determinados grupos religiosos nas periferias das cidades e de sua forte influência perante a mídia, além das contraditórias políticas educacionais do Estado que, embora defendam a laicidade do Estado, produzem leis sobre o ensino religioso nas escolas, de forma ecumênica. ${ }^{54}$ Isso revela mais que contradições, revela situações de conflitos de interesse e de poder que geram tensões na sociedade causadas pelas diferentes religiões ${ }^{55}$.

Os dados resultantes das experiências vividas nas missões serão parte integrante do relatório nacional apresentado perante o Congresso Nacional, o Conselho Nacional de Educação, o Ministério Público Federal, as autoridades educacionais, os organismos das Nações Unidas e demais instâncias internacionais de direitos humanos.

Outro importante destaque contido no informe n. ${ }^{\circ}$ 2009/2011 da Plataforma DhESCA é que, para receber denúncias acerca do racismo na educação, a relatoria disponibiliza dois canais de contato (telefone ou e-mail) para o encaminhamento dos casos.

54 O ensino religioso tornou-se realidade em nosso Estado a partir da deliberação do Conselho Estadual da Educação número 16, do dia 27 de julho de 2001, que regulamentou o artigo 33 da Lei 9.394, da Lei de Diretrizes e Bases da Educação Nacional, com nova redação dada pela Lei 9.475/97.

55 "Ora, para que o caráter facultativo seja efetivo e a possibilidade de escolha se exerça como tal, é necessário que, dentro de um espaço regrado como o é o das instituições escolares, haja a oportunidade de opção entre o ensino religioso e outra atividade pedagógica igualmente significativa para tantos quantos que não fizerem a escolha pelo primeiro. Não se configura como opção a inatividade, a dispensa ou as situações de apartamento em locais que gerem constrangimento. Ora, essa(s) atividade(s) pedagógica(s) alternativa(s), constante(s) do projeto pedagógico do estabelecimento escolar, igualmente ao ensino religioso, deverão merecer, da parte da escola para os pais ou alunos, a devida comunicação, a fim de que estes possam manifestar sua vontade perante uma das alternativas". (CURY, 2004, p. 189). 


\subsection{A educação e o relatório brasileiro de 2003}

O primeiro relatório brasileiro sobre os DhESC advém do período em que o grupo de relatores nacionais que fora nomeado em outubro de 2002, tendo realizado suas primeiras missões a partir de novembro do referido ano, faz a apresentação de seus primeiros relatórios em abril de 2003, perante as Nações Unidas, e, em maio de 2003, perante a Conferência Nacional de Direitos Humanos, que ocorre todos os anos em Brasília e é marcada pela participação da sociedade civil brasileira (RELATÓRIO..., 2003).

A missão desse grupo de relatores nomeados em 2002 pelo Conselho de Escolha dos Relatores Nacionais em Direitos Humanos Econômicos, Sociais e Culturais $(\mathrm{DhESC})^{56}$, constituído por seis organizações da sociedade civil ${ }^{57}$, quatro organismos do Estado Brasileiro $^{58}$ e outras três entidades ligadas às Nações Unidas ${ }^{59}$, ocorreu na cidade de Fortaleza, contando com o relator nacional para o direito humano à educação, Sérgio Haddad, e com a assessora da relatoria, Mariângela Graciano (vide apêndice A).

O conteúdo do relatório referente ao direito humano à educação é datado de março de 2003, em que procura analisar como a educação no Brasil havia sido tratada, até aquele momento, sob o ponto de vista dos direitos humanos. Para tanto, realiza um apanhado geral

56 Conforme mencionado anteriormente, reitera-se que: "a escolha dos relatores nacionais teve por base a utilização de critérios que combinam a capacidade profissional, a capacidade de articular amplos setores nacionais, a disponibilidade para o trabalho em caráter voluntário, com elementos de diversidade racial, de gênero e regional. O desafio desses especialistas tem sido o de monitorar a situação dos direitos humanos no país de forma exemplar, o que implica em conhecer profundamente os problemas relacionados ao seu mandato; articular amplos setores sociais em busca de cooperação e soluções para os problemas verificados; e apresentar soluções viáveis por meio de políticas públicas e de novas leis que venham a melhorar a qualidade de vida da população brasileira. Durante o período de seu mandato, os relatores são irremovíveis e desenvolvem um trabalho em capacidade independente, embora tenham o trabalho balizado por um Termo de Mandato, com elementos comuns a todos e específicos, construídos com a participação da sociedade organizada, no Seminário para a Construção da Metodologia de Trabalho dos Relatores Nacionais em DhESC, realizado em São Paulo, em outubro de 2002". (RELATÓRIO..., 2003, p. 8-9).

57 Citam-se: Federação de Órgãos para a Assistência Social e Educacional (FASE); Movimento Nacional de Direitos Humanos (MNDH); Gabinete de Assessoria Jurídica às Organizações Populares (GAJOP); Centro de Justiça Global; FoodFirst Information \& Action Network - Rede de Ação e Informação pelo Direito a se Alimentar (FIAN - Brasil) e Comissão de Justiça e Paz de São Paulo. (RELATÓRIO..., 2003, p. 8).

58 São eles: Comissão de Direitos Humanos da Câmara Federal; Departamento de Direitos Humanos do Ministério das Relações Exteriores; Procuradoria Federal dos Direitos do Cidadão e Secretaria Especial de Direitos Humanos. (RELATÓRIO..., 2003, p. 8).

59 São elas: Fundo das Nações Unidas para a Infância (Unicef); United Nations Volunteers (UNV); Programa das Nações Unidas para o Desenvolvimento (Pnud). (RELATÓRIO..., 2003, p. 8). 
sobre as normas onde estão contidos esses direitos, expõe a situação da educação naquele contexto, narra a experiência vivida por aqueles relatores durante a missão em Fortaleza, e, por fim, apresenta suas conclusões e recomendações.

\subsubsection{Aspectos gerais da educação no relatório brasileiro de 2003}

Ao tratar do sistema de ensino brasileiro, o relatório expõe a tentativa de redução da desigualdade educacional: nos últimos dez anos houve praticamente a universalização do atendimento no ensino fundamental e um crescimento no atendimento do ensino médio em proporção maior que nos outros níveis de ensino. Além disso, houve uma queda no atendimento das chamadas classes de alfabetização, caracterizadas por serem unidades isoladas de ensino que estavam sendo pouco a pouco incorporadas ao ensino fundamental, sendo elas características das regiões mais pobres do Brasil (Norte e Nordeste). (RELATÓRIO..., 2003, p. 211-212).

Com relação ao número de matrículas totais, os números do relatório revelaram o seu crescimento, como resultado do incentivo da democratização da oferta, que, no período de 1991 a 2000, considerando-se a somatória do ensino pré-escolar, do ensino fundamental e do ensino médio, ocorreram em proporção maior nas regiões mais pobres do Brasil, em relação ao Sul e Sudeste, considerados como locais de maior renda.

Constatou-se também que a principal causa do crescimento do ensino básico no Brasil se deu por meio da ampliação do ensino público, sendo que a participação do ensino privado na educação básica era minoritária em todos os graus. Por outro lado, no ensino superior prevalecia a iniciativa privada.

Além disso, tem-se que o governo federal possui um papel fundamental sobre a equidade na distribuição dos recursos em relação aos outros entes da federação, contando com a participação de apenas $1 \%$ das matrículas no ensino básico, mas com maior atribuição de responsabilidade pelo ensino superior e por algumas escolas técnicas de nível médio.

Assim sendo, grande parte das desigualdades no sistema educacional ficam bastante expostas quando o relatório enfrenta a questão dos limites do atendimento, revelando as insuficiências da expansão quanto à quantidade e à qualidade do ensino. 
Nesse tópico, os dados indicam que não houve a universalização do atendimento escolar, mesmo tendo crescido o número de vagas. Na faixa etária compreendida entre os 7 e os 14 anos de idade, constatou-se que era maior o número de meninas fora da escola em relação ao número de meninos, sendo que, em virtude do não atendimento da escolaridade obrigatória, elevaram-se as taxas de analfabetismo absoluto entre jovens e adultos. (RELATÓRIO..., 2003, p. 216).

Outra conclusão importante refere-se à qualidade do ensino, que não apresentou melhoria, apesar do crescimento da oferta de vagas. Isso se deve a alguns fatores de ordem econômica, tais como: precária qualificação dos professores, baixos salários, elevado número de alunos em sala de aula, tempo de aulas reduzido, instalações materiais inadequadas, falta de material pedagógico, entre outros.

A combinação desses elementos fez com que houvesse elevados índices de evasão e repetência que, apesar de sua diminuição nos últimos anos, ainda eram bastante elevados (19,5\% no Brasil).

Por trás desse índice, estavam inseridas as desigualdades regionais, onde, nas regiões Norte e Nordeste, encontraram-se os mais altos índices de evasão e repetência: $27,3 \%$ e $27,5 \%$, respectivamente, confirmando a incompatibilidade entre a demanda e a qualidade da oferta. (RELATÓRIO..., 2003, p. 217-218).

Alguns fatores de ordem cultural também influenciaram bastante o aproveitamento dos educandos, como, por exemplo, o fato de que, antes da massificação, a escola pública recebia um público elitizado, passando, depois, a se deparar com uma população mais pobre e com uma diferente cultura escolar, que se encontra, na escola, com professores também provenientes de famílias com pouca vivência da cultura escolar e com poucos elementos para conseguir dar conta dos novos parâmetros exigidos nacional e internacionalmente.

Outro fenômeno provocado pela soma dos altos índices de evasão e repetência com o grande número de crianças e jovens fora do sistema de ensino foram as altas taxas de defasagem entre idade e série.

Essa situação dá ensejo a um baixo nível de escolaridade média no País, constatada pelo alto índice de analfabetismo funcional (pessoas que possuem apenas de um a três anos de escolaridade). Isso significa que, somando-se estes índices à quantidade de analfabetos absolutos, existiam 42.844.220 pessoas acima de 10 anos que estavam impossibilitadas de ler e escrever, representando $31,4 \%$ da população dessa faixa etária. Da mesma forma que as anteriores, estes índices foram agravados na região Nordeste: $17,92 \%$ da população 
desta faixa etária eram analfabetos absolutos, representando mais que o triplo da Região Sul, enquanto que 28,93\% eram analfabetos funcionais. (RELATÓRIO..., 2003, p. 218219).

Quanto à qualidade do ensino médio, o resultado do Exame Nacional do Ensino Médio - Enem 2001 demonstrou a existência de um baixo desempenho para todos os grupos sociais. No entanto, os alunos de escolas públicas possuíam rendimento inferior aos das escolas privadas, sendo que os grupos com maior atraso de escolaridade eram constituídos pelos não brancos. Quanto ao gênero, tem-se que as mulheres possuíam desempenho bastante inferior aos homens na avaliação "objetiva”, possuindo apenas melhor resultado em redação, apesar da pequena diferença constatada. (RELATÓRIO..., 2003, p. 220).

Com relação à qualidade do ensino básico, ela se apresentava boa apenas para um número muito reduzido de escolas privadas que atendiam as minorias de elevado poder aquisitivo.

Por sua vez, no ensino superior, verifica-se que as instituições de melhor qualidade eram as públicas, frequentadas, em sua maioria, por estudantes de maior poder aquisitivo, que tiveram acesso a uma educação básica de melhor qualidade, refletindo melhores resultados nos concursos de ingresso, em detrimento daqueles que não tiveram acesso a melhores oportunidades no passado escolar.

Outro fator de grande impacto na qualidade do ensino era a baixa remuneração dos professores, que fazia com que aqueles com maior experiência e formação migrassem para o ensino privado ou outras ocupações, ficando no ensino público apenas aqueles mais jovens, com menor experiência e formação.

Por não haver, ainda, naquele momento, um piso salarial nacional ${ }^{60}$ nem um plano de carreira docente, a baixa remuneração dos professores refletia ainda mais as

60 A EC n. ${ }^{\circ}$ 53/2006, além de criar o Fundo de Manutenção e Desenvolvimento da Educação Básica e de Valorização dos Profissionais da Educação - Fundeb, instituiu, no inciso VIII do art. 206 da Constituição, novo princípio do ensino: o piso salarial profissional nacional para os profissionais da educação escolar pública. Segundo a referida EC, tanto o Fundeb como o Piso deveriam ser regulamentados em leis federais específicas, cuja iniciativa legislativa caberia ao Poder Executivo Federal.

O novo inciso VIII do art.206 da Constituição foi parcialmente regulamentado pela Lei $\mathrm{n}^{\circ} 11.738 / 2008$, que dispõe sobre o piso salarial profissional nacional para os profissionais do magistério público. Tal norma está inserida em um amplo processo de reforma do financiamento da educação básica, fundado na Emenda Constitucional (EC) n. ${ }^{\circ}$ 53/2006 e regulamentado pela Lei n. ${ }^{\circ}$ 11.494/2007, que trata do Fundo de Manutenção e Desenvolvimento da Educação Básica e de Valorização dos Profissionais da Educação - Fundeb. Esta reforma se caracteriza pela ampliação global dos recursos públicos vinculados a esta etapa de ensino, principalmente com a elevação da participação da União em sua manutenção e desenvolvimento. (AÇÃO EDUCATIVA, 2011b). 
desigualdades regionais, pois os docentes eram obrigados a se sujeitar às condições econômicas das regiões a que pertenciam. Nesse sentido, os professores do Nordeste eram os que tinham os piores salários, em todos os níveis de escolaridade.

O relatório demonstra, ainda, que se anteriormente um dos grandes problemas na educação era a exclusão do acesso, pela falta de oferta de vagas, a ampliação do número de vagas não vinha acompanhada por um padrão mínimo de qualidade o que acabava por gerar um novo tipo de exclusão, que era a falta de permanência dos alunos na escola para completar a sua escolarização. Os dados coletados pela missão revelam que de 100 alunos que ingressavam no ensino fundamental, apenas 59 conseguiam terminar a oitava série e somente 40 chegavam ao final do ensino médio. (RELATÓRIO..., 2003, p. 222).

Apesar desta alarmante situação, as políticas públicas de incentivo à escolarização são escassas, fracassando na tarefa de evitar a evasão e a repetência, bem como de garantir o acesso à escola àqueles que não o tiveram na idade apropriada.

Constatou-se também, por meio dos dados apontados pelo IBGE, que, apesar dos avanços na escolaridade dos brasileiros, ainda permanecem as desigualdades raciais nesse sentido: em 2001, os brancos possuíam, em média, 6,7 anos de estudos, contra 4,5 anos de escolaridade média dos negros.

Além disso, dados coletados pelo MEC indicam que o número de negros que se formam nas universidades constitui apenas $15,7 \%$ do total, não condizente com o número de $45,2 \%$ de negros que integram a população brasileira ${ }^{61}$. (RELATÓRIO..., 2003, p. 223 224).

A desigualdade também está presente no que diz respeito à educação especial para os brasileiros com necessidades especiais de todas as ordens: dentre os 5.507 municípios pesquisados, 59,1\% não disponibilizavam este tipo de educação, sendo que as diferenças são ainda mais salientes nas diferentes regiões do país: na região Nordeste, 78,3\% dos municípios não o possuem, enquanto que no Sul, este número reduz-se para 41,9\%.

A situação de exclusão dos indígenas é ainda mais evidente, revelada pela quantidade ínfima de recursos que foram alocados para sua educação em 2003, representada pelo índice de $0,001 \%$ do orçamento federal, limitando-se apenas a algum tipo de educação rural.

O relatório demonstrou, ainda, que os diversos indicadores, ao serem cruzados, deflagram uma situação mais nítida em relação às violações ao direito à educação,

61 Considerando a soma da população que se autodeclara preta e parda nos censos. 
significando que o analfabetismo possuía endereço definido, como por exemplo, era o caso das $36,67 \%$ das pessoas sem instrução que viviam na zona rural do Nordeste.

Vale dizer que, apesar da existência de medidas advindas do poder público, como o aumento da oferta do ensino fundamental, fatores diversos, como a deficiente qualidade do ensino, os altos índices de pobreza concentrados em alguns regiões e grupos sociais, bem como questões de gênero, etnia e faixa etária, acentuavam fatores de desigualdade entre determinados grupos, significando que o sistema escolar brasileiro mantém mecanismos de discriminação e de exclusão. (RELATÓRIO..., 2003, p. 225-226).

Quanto ao financiamento e os gastos do ensino público no Brasil, tem-se que o investimento do governo federal com educação em 2002 representou 1,83\% do total da despesa efetuada pela União, significando que nem todo o valor orçado $(2,01 \%)$ foi gasto.

O que ocorre é uma desigualdade nos gastos públicos por aluno em relação a cada uma das regiões, acentuando ainda mais as diferenças regionais.

O Fundo de Manutenção e Desenvolvimento do Ensino Fundamental e de Valorização do Magistério (Fundef) passou a vigorar desde $1^{\circ}$ de janeiro de 1998, implementando um novo mecanismo de redistribuição dos recursos destinados ao Ensino Fundamental. (RELATÓRIO..., 2003, p. 227-231).

A criação do Fundef possibilitou uma maior redistribuição de recursos e uma consequente diminuição das desigualdades regionais no financiamento do ensino Fundamental.

Porém, a crítica que se faz a esse fundo é o fato de ter excluído da educação fundamental, a educação de jovens e adultos, violando totalmente os direitos das pessoas que se enquadram nesta categoria, além de preterir os recursos para a educação infantil.

Isso fez com que o Estado desviasse o foco de sua responsabilidade redistributiva e pela melhoria da qualidade de ensino, desde a valorização dos salários aos profissionais até o incremento das condições materiais.

Outro grave problema constatado são os desvios de investimentos em educação para outras finalidades, bem como os altos índices de corrupção da administração pública, onde fica evidenciado o sobrepujamento dos interesses públicos para a prevalência dos interesses particulares.

A conjunção de alguns fatores, tais como o desinteresse da sociedade civil no controle e fiscalização dos recursos públicos, além do complexo mecanismo de funcionamento do sistema orçamentário, colaboram para a manutenção da corrupção. 


\subsubsection{Aspectos específicos sobre o trabalho de campo: a missão educacional no Ceará}

Até 2003, época em que foi feita a missão ao Ceará, especificamente entre os dias 18 e 21 de fevereiro de 2003, este Estado ocupava o segundo lugar dentre os municípios com os maiores índices de exclusão escolar. (RELATÓRIO..., 2003, p. 232).

Dentre a faixa etária de 15 anos ou mais, a taxa de analfabetismo era de 25,4\%, representando menos que a taxa da Região Nordeste, com cerca de $26,2 \%$, e mais que a do Brasil, correspondente à 13,6\%, de acordo com o Censo Demográfico de 2000.

Com relação à taxa de escolarização líquida para o ensino fundamental, representava 93,2\%, sendo menor que a nacional (94,3\%), mas superior à da Região Nordeste $(92,8 \%)$. No que diz respeito ao ensino médio, o desempenho do Estado $(20,1 \%)$ era menor que a nacional $(33,3 \%)$, porém, acima da regional $(16,7 \% \%)$.

$\mathrm{O}$ atendimento estadual para a população de 7 a 14 anos era 96,1\%, maior que a taxa regional (95,2\%) e menor que a nacional (96,4\%). Na faixa etária dos 15 aos 17 anos, o atendimento do Estado representava $86,6 \%$, sendo maior que as taxas regional $(82,4 \%) \mathrm{e}$ nacional (83,0\%), de acordo com dados do MEC/Inep de 2001.

Quanto à distribuição de matrícula por sexo, os dados de 2001 demonstravam que a presença de mulheres era menor apenas no ensino fundamental, com uma taxa de 49,27\%, enquanto que para os homens, esta taxa ficava entre os 50,73\%. Corroborando tal afirmação, verificava-se que para o ensino médio, as taxas ficavam entre 55,98\% de mulheres, e $44,02 \%$ de homens, e para o ensino superior, as mulheres representavam $53,9 \%$, contra $46,1 \%$ dos homens, de acordo com a mesma fonte anteriormente citada.

A infraestrutura das escolas era muito precária, sendo que 58,5\% das escolas não ofereciam quadra de esportes, e 51,2\% não possuíam biblioteca.

Foi diante deste quadro e do recebimento de denúncias quanto à violação ao direito à educação, realizadas pela Comissão de Defesa do Direito à Educação, Fórum Interinstitucional de Educação e Comitê Cearense da Campanha Nacional pelo Direito à Educação, que foi realizada a missão da Relatoria Nacional para o Direito Humano à Educação em Fortaleza, no período compreendido entre os dias 18 e 21 de fevereiro de 2003. (RELATÓRIO..., 2003, p. 235).

Ao serem recebidas as denúncias, elas foram organizadas de acordo com dois temas principais: os problemas referentes ao acesso e aqueles relativos à qualidade. No primeiro 
caso, as denúncias tratavam da falta de vagas no ensino infantil e ensino médio, bem como para pessoas portadoras de necessidades especiais.

Já no segundo caso, as denúncias davam conta da má qualidade do atendimento em creches e pré-escola em Fortaleza, a precariedade das instalações para atender a pré-escola e as escolas de ensino fundamental, assim como o sistema Telensino e o ensino médio, a falta de políticas públicas voltadas para a educação de jovens e adultos, além das péssimas condições materiais oferecidas aos profissionais da área da educação.

A Relatoria averiguou as denúncias por meio de visitas a estabelecimentos de ensino estaduais e municipais, sendo que os temas nelas tratados entraram na pauta de encontros realizados entre a Relatoria e os gestores públicos responsáveis, àquela época, pelas políticas educacionais do Estado e do município. (RELATÓRIO..., 2003, p. 236).

Quanto à educação infantil, as denúncias relativas à oferta insuficiente de vagas referia-se a um déficit de 205,1 mil vagas, em que, na faixa etária dos 0 aos 3 anos, a oferta cobria menos de $10 \%$ da demanda, e para a faixa dos 3 aos 6 anos, a cobertura era de apenas $60 \%$.

Para os denunciantes, o poder público municipal não realizava a devida divulgação do período de matrículas para o ensino infantil, impedindo que as pessoas tivessem o respectivo acesso ao direito.

Já nas creches ligadas ao Estado, os professores não possuíam a formação exigida na Lei de Diretrizes e Bases da Educação e, dentre as denúncias de precariedade das condições materiais, cita-se o exemplo constatado pela Relatoria nas visitas às creches "Sonho Infantil" e "Santa Edwiges", em que havia problemas com as instalações hidráulicas e elétricas; os colchões onde as crianças repousavam encontravam-se úmidos e rasgados, não havendo itens básicos para o bom funcionamento dos banheiros, tais como: porta, luz elétrica e papel higiênico.

Além disso, não havia qualquer material pedagógico, nem qualquer tipo de acomodação para as crianças permanecerem sentadas. A remuneração de todas as funcionárias, não importando o tipo de função que exerciam, era sempre o de um salário mínimo, equivalente à época a uma quantia de duzentos reais.

Com base nisso, a Recomendação da Relatoria foi no sentido de dar continuidade à ampliação da rede de educação infantil, com vistas a se garantir a universalização do atendimento, e em providências urgentes para a melhoria das condições de infraestrutura física e pedagógica das unidades em funcionamento. (RELATÓRIO..., 2003, p. 238). 
O Telensino, método de aprendizado utilizado em todo ensino fundamental do Ceará, que diz respeito à transmissão de programas de TV educativos acompanhados em sala de aula por um "orientador de aprendizagem", sofreu denúncias relativas à falta de qualidade.

Isso ficou comprovado pelo sistema de avaliação estadual, cujo resultado apresentado foi o de que o desempenho de um aluno da $8^{\mathrm{a}}$ série do sistema Telensino era equiparado ao de um aluno da $4^{\mathrm{a}}$ série do sistema presencial.

Os problemas ali constatados iam desde a defasagem do material didático, bem como a falta de quantidade suficiente para todos os alunos e professores. Além disso, estes últimos acabavam prestando orientações em todas as disciplinas, apesar de possuírem uma única especialidade.

Segundo a avaliação técnica da Secretaria da Educação, a queda na qualidade do Telensino se deveu ao processo de universalização, em que os professores se viram obrigados a adotar o sistema, prejudicando o seu rendimento e interferindo diretamente em sua qualidade.

No entanto, apesar de ter sido cogitada a extinção do Telensino, a posição defendida pela Secretaria era de que, caso isso acontecesse, haveria a paralisação do sistema educacional daquele Estado. Com isso, as propostas da Secretaria Estadual foram no sentido de se investir na atualização do material, e tornar o sistema opcional. Para a Relatoria, a recomendação foi no sentido de se iniciar a imediata e progressiva substituição do Telensino pelo sistema regular.

Quanto ao ensino médio, a denúncia feita à missão era com relação à má qualidade e insuficiência ao seu acesso. No primeiro caso, a causa apontada seria a atuação de professores não especializados e a implementação de programas de TV preparados pela Fundação Roberto Marinho, que também contribuíam para a disseminação de monitores não especializados. (RELATÓRIO..., 2003, p. 241-242).

Para tentar reverter o problema da baixa qualidade do ensino médio, atribuído à falta de preparo dos professores, a Secretaria passou a propor medidas como reuniões do conselho de escola nos encontros pedagógicos e a maior participação dos alunos no cotidiano pedagógico e administrativo da escola, além de deixar para o próprio aluno optar pelo sistema convencional ou o supletivo televisivo denominado "Programa Tempo de Avançar para o Ensino Médio".

Durante visita ao estabelecimento de ensino "Bom Jesus de Praga", a Relatoria encontrou situações como falta de aparelho de TV e vídeo para aplicar o programa 
supletivo televisivo, sob a alegação de que ambos ficavam guardados em uma sala separada para se evitar furtos.

Além disso, constatou-se grande diversidade na faixa etária dos alunos, encontrando-se desde adolescentes até pessoas da terceira idade. Porém, apesar de a maioria absoluta manifestar o interesse em continuar nos estudos, alguns educandos relataram que tentaram matricular-se no ensino médio regular, mas não encontraram vagas, o que os obrigou a participar do programa supletivo televisivo.

Com isso, a recomendação da Relatoria foi no sentido de reverter a ampliação do programa Tempo de Avançar para o Ensino Médio, para que houvesse maior ampliação com vistas à universalização do sistema regular de ensino, bem como a fiscalização, por parte da Secretaria Estadual de Educação, do sistema de transporte, visando a garantir maior segurança aos estudantes.

Outra denúncia à missão foi motivada pela ausência de políticas públicas para a educação de jovens e adultos, em que o Estado e os municípios não dispunham de ações conjuntas e abrangentes para permitir que esta categoria de educandos permanecesse na escola regular. Foi constatado que houve apenas uma ampliação de oferta no ensino supletivo, com baixa e insuficiente produtividade para atender a todos. (RELATÓRIO..., 2003, p. 242-244).

Quanto ao acesso, esta modalidade de educação não estava incluída na proposta político-pedagógica da escola regular, além das unidades de atendimento a esta categoria de pessoas estarem distante das moradias dos estudantes.

Aqui também havia o mesmo problema apontado anteriormente, com relação à universalização do programa supletivo televisivo e à falta de preparo dos monitores. Com relação a isso, o secretário municipal de educação afirmou que o problema não era de insuficiência no atendimento da demanda, mas sim dos altos índices de evasão.

Apesar disso, verificou-se, nas visitas da missão a duas unidades dessa categoria de ensino, o esforço dos educadores para manter a frequência dos alunos, através de iniciativas como a organização de laboratórios de Química e Física, biblioteca, cursos de artesanato, informática e atividades de lazer.

Porém, o que se verificou nesta modalidade de ensino não foi só um problema vivido em Fortaleza, mas em todo o País, em que não há unidade nas iniciativas, dissipando-se pelas diferentes esferas de governo, e significando uma grande perda de recursos e esforços, além das limitações de alcance das iniciativas. 
Outro grande problema constatado pela Relatoria referente aos programas supletivos foi de que havia um sério fator de exclusão dos alunos nas instalações a eles destinadas, denominados “prédios Anexos”. (RELATÓRIO..., 2003, p. 244-247).

Destaca-se o fato de que, num estabelecimento, em uma sala de aula, dos quarenta alunos matriculados, apenas dois frequentaram o programa supletivo ofertado pelo Governo do Estado. Uma das razões disso era a precariedade das instalações diante da quantidade de alunos. No caso do anexo "Bom Jesus de Praga", em uma sala de aproximadamente 21 metros quadrados, havia apenas uma pequena janela e um total de 59 alunos matriculados. No dia da visita, constatou-se que a sala já estava repleta com um total de cerca de 30 alunos, não havendo a menor possibilidade de ocupar o mesmo espaço físico aquele total de alunos matriculados.

Assim sendo, tratava-se de situação de risco à própria segurança dos educandos, devido à insalubridade originada pela precariedade daquelas instalações, em que obrigar os alunos a permanecer durante horas em locais insalubres representava violação à própria condição humana.

Além disso, naquele mesmo ano, a Comissão de Defesa do Direito à Educação havia visitado 33 "Anexos" de Fortaleza, constatando que, em alguns deles, os alunos da educação infantil estudavam das $10 \mathrm{~h} 30$ às $14 \mathrm{~h}$ sem merenda; não havendo sequer água filtrada; a separação das escolas patrimoniais era feita por rodovias; não havia formação dos professores prevista em lei, além de diversos outros riscos à segurança dos alunos.

As recomendações da Relatoria para estes problemas foram no sentido de substituição do programa supletivo pelo ensino fundamental no sistema regular de ensino, além de fazer-se um planejamento organizado e centralizado de ações conjuntas entre os governos estadual e municipal, visando-se à continuidade escolar dos educandos. Quanto aos prédios “Anexos", recomendou-se sua supressão imediata, através da constituição de uma comissão composta por representantes da sociedade civil, governo estadual e municipal.

Quanto à precarização das relações de trabalho pelo Governo do Estado e municípios, as denúncias foram no sentido da ausência de realização de concursos públicos, para a contratação de professores em regime temporário. (RELATÓRIO..., 2003, p. 247-248).

Tal atitude, além de representar violação a direitos trabalhistas, provoca atraso no início do ano letivo, conforme noticiado pela imprensa, e permite com que haja a atuação de professores não habilitados. 
A recomendação da Relatoria para esta questão foi de dar continuidade aos concursos públicos divulgados pela Secretaria Estadual de Educação para a contratação de professores habilitados para a função, respeitando-se as leis trabalhistas e a Constituição Federal do Brasil.

Com relação à educação especial, a denúncia feita à Relatoria dizia respeito à falta de atendimento aos alunos portadores de necessidades especiais na educação infantil e no ensino fundamental. (RELATÓRIO..., 2003, p. 248-249).

Os relatos foram no sentido de que prevalecia a prática de encaminhá-los às unidades da Associação de Pais e Amigos dos Excepcionais (Apae), organização da sociedade civil presente em todo o País, por falta de preparo dos professores.

Durante toda a missão da Relatoria em Fortaleza, não foi encontrado sequer um aluno nas escolas nessas condições. O pior de tudo é que tal situação não causava estranheza às equipes das escolas, devido à prática disseminada do encaminhamento imediato às instituições especializadas. Além disso, não havia qualquer adaptação nas instalações físicas das escolas para receber este tipo de aluno, o que é fato consolidado em todo o nosso País.

A recomendação da Relatoria foi no sentido de criar políticas para a universalização desse tipo de educação no sistema regular de ensino, em conjunto com outras iniciativas de cunho estadual e municipal para a inclusão e atendimento a este setor da população.

Para encerrar a missão, a Relatoria participou de uma audiência pública na Assembleia Legislativa, em 21 de fevereiro de 2003, onde estiveram presentes gestores estaduais e municipais, representantes do Ministério Público Federal e do Conselho Estadual de Educação. (RELATÓRIO..., 2003, p. 250-251).

Naquela oportunidade, as organizações da sociedade civil relataram suas denúncias, acompanhadas das respostas dos gestores sobre suas ações para a superação dos problemas apresentados.

As violações foram consideradas em dois grupos pelo relator: as ações insatisfatórias na garantia da universalidade no acesso e qualidade para a educação de jovens e adultos, ensino médio e educação infantil em todo o País; e as situações específicas, relacionadas às políticas estadual e municipal, em que estão inseridas as péssimas condições de instalações, como as dos prédios “Anexos” às escolas patrimoniais, a falta de qualidade do sistema Telensino, as precárias relações de trabalho dos professores e a ausência de políticas de inclusão às pessoas portadoras de necessidades especiais. 
O relator destacou os esforços destinados à melhoria de alguns destes problemas, ressaltando a importância e o bom exemplo da participação das organizações da sociedade civil cearense na fiscalização das políticas educacionais, como um modelo a ser seguido em todo o País.

A conclusão da missão da Relatoria no Ceará foi de que o Brasil realizou grandes reformas na economia e nas estruturas do Estado, por pressões advindas do fenômeno da globalização econômica. Com isso, a esfera social teve de se organizar para atender às necessidades de processos de democratização política, porém, com restrições de ordem econômica. Dessa forma, procurou-se fazer aumentos quantitativos com relação à cobertura e ao acesso, principalmente no ensino fundamental, utilizando-se de recursos escassos. O resultado disso foi a grande perda de qualidade do ensino público.

Diante disso, configura-se praticamente inviável a implementação do viés da educação como um direito humano em nosso País, devido à enorme desigualdade de oportunidades e condições de vida precárias da maioria da população. No entanto, tem-se que, para esta melhoria das condições de igualdade de oportunidades, uma importante saída seria a própria educação pública de qualidade.

Disseminou-se, portanto, uma nova forma de exclusão social na educação, não mais pela ausência de vagas, mas pela péssima qualidade de ensino ofertado, incapaz de fazer com que o aluno aprenda o mínimo necessário.

\subsection{O relatório de 2004 sobre a violação dos direitos educativos nos estados de Alagoas e Amazonas}

O presente tópico visa apresentar os resultados do sucinto relatório sobre a política educacional existente no Brasil no intervalo de janeiro de 2003 a setembro de 2004, derivado da missão da Relatoria Nacional para o Direito Humano à Educação nos estados de Alagoas e Amazonas, contando com a participação de Sérgio Haddad como relator nacional e Mariângela Graciano como assessora nacional. Neste item serão apresentados os aspectos gerais contidos no relatório e, após, as peculiaridades observadas na missão sobre educação da Relatoria em ambas as localidades.

Ressalta-se que este relatório foi extraído do Informe 2004 das Relatorias Nacionais em Direitos Humanos Econômicos, Sociais e Culturais, constituindo parte integrante do 
levantamento de informações realizado pela Relatoria Nacional para o Direito Humano à Educação, ao lado de outros relatórios que compõem o referido Informe, relativos aos seguintes temas de direitos humanos: alimentação, água e terra rural, meio ambiente, moradia e terra urbana, saúde e trabalho.

A importância deste item refere-se a uma das conclusões obtidas com a pesquisa da Relatoria Nacional para o Direito Humano à Educação, ou seja, a de que, apesar das violações à educação registrarem algumas especificidades locais, indicam também situações comuns ao País como um todo, representados pelos óbices que impossibilitam a efetivação universal do direito humano à educação. Dentre eles, citam-se a corrupção na administração pública e suas desastrosas consequências, a precária físcalização dos recursos públicos e o desrespeito às características culturais das populações indígenas brasileiras no tocante à implementação de sua educação escolar.

\subsubsection{Aspectos gerais da educação no relatório}

A premissa básica adotada pela Relatoria é a de que a educação representa o pilar da formação do ser humano, além de exercer papel fundamental na defesa e constituição de outros direitos de ordem econômica, social e cultural.

Com isso, o ponto de partida para a observação por parte da Relatoria tem sido o direito à educação escolar, cuja efetivação deve ocorrer por meio de políticas públicas governamentais. (RELATORIAS NACIONAIS EM DIREITOS HUMANOS ECONÔMICOS, SOCIAIS E CULTURAIS, 2004, p. 28).

No entanto, apesar desse direito estar estabelecido em lei, ao contrário de muitos países do terceiro mundo, no Brasil ocorrem problemas relativos à sua implantação.

Um exemplo disso é que o governo brasileiro criou o Programa Brasil Alfabetizado, por intermédio do Ministério da Educação para democratizar o acesso à educação em todos os níveis. Apesar desta campanha representar um grande avanço em relação às anteriores, por reconhecer a iniciativa do governo nesta área e prever mecanismos de controle social, seu lançamento se deu de maneira incorreta em relação à erradicação do analfabetismo, prevendo um número maior de jovens e adultos que não sabem ler e escrever do que a realidade. 
O pior cenário, no entanto, foi o de que se criou uma expectativa de atendimento sem criar as condições necessárias para tal, pois não houve qualquer estudo nem pesquisa sobre os mecanismos de atendimento e ações anteriores no sistema público de ensino voltado a este grupo específico. Além disso, os recursos públicos destinados a tal iniciativa não foram suficientes para atingir esta meta anunciada como uma das prioridades do governo.

O mesmo ocorreu com relação ao Fundo de Desenvolvimento do Ensino Fundamental e Valorização do Magistério (Fundef), pois apesar de se propor universalizar o acesso em relação às categorias excluídas nos programas governamentais anteriores, não houve a apresentação de um estudo indicativo da quantidade de recursos necessária à manutenção da iniciativa ao longo do tempo.

O que se percebe, portanto, é que o governo federal cria programas visando formalmente à universalização do direito à educação e à superação das desigualdades, sem, no entanto, tornar tais expectativas viáveis do ponto de vista prático, devido à ausência de recursos e planejamento adequados, tal como existente nos governos anteriores.

\subsubsection{Aspectos específicos sobre o trabalho de campo}

Em Alagoas, a principal constatação realizada pela Relatoria foi em relação às denúncias de irregularidades na utilização dos recursos públicos federais destinados à educação. (RELATORIAS NACIONAIS EM DIREITOS HUMANOS ECONÔMICOS, SOCIAIS E CULTURAIS, 2004, p. 31-32).

Com base nisso, tem-se que o Conselho Estadual de Educação daquele Estado, em 20 de novembro de 2003, afirmou que um dos aspectos da utilização irregular dos recursos públicos está no grande número de escolas que funcionam em locais considerados completamente inadequados.

Além disso, no município de Traipu, professoras confirmaram essa afirmação, acrescida de que o poder público local manipula o número de alunos matriculados de modo a ampliar o repasse de verbas. Um exemplo disso é da existência de turmas com mais de oitenta alunos matriculados, enquanto que na realidade, apenas 30 alunos a frequentam regularmente, além da merenda escolar mensal ser suficiente para apenas 15 dias. E por delatarem tal situação envolvendo os prefeitos e políticos da região, muitos profissionais 
da educação já sofreram diversas ameaças ou retaliações, tendo em alguns casos resultado no próprio assassinato do denunciante.

Já no Amazonas, a Relatoria identificou muitas situações semelhantes de tensões e controvérsias envolvendo a questão da educação indígena em relação a outros Estados, por se tratarem de políticas federais. De um modo geral, foram constatadas adversidades relativas à responsabilidade administrativa em torno desta modalidade de ensino, barreiras a serem superadas para se respeitar a diversidade cultural e demais peculiaridades inerentes a esse grupo específico, a superação de limites históricos, como a convivência desses grupos com outros que se arraigaram nesses locais, como, por exemplo, militares e religiosos, a busca dos indígenas por autonomia e participação em seu processo educativo, bem como os limites dos recursos públicos para o investimento na educação. (RELATORIAS NACIONAIS EM DIREITOS HUMANOS ECONÔMICOS, SOCIAIS E CULTURAIS, 2004, p. 33-35).

Especificamente naquele Estado, constatou-se que a responsabilidade dos entes administrativos sobre a educação escolar indígena permanece sem definição. O governo do Estado atribui a responsabilidade desta modalidade de ensino aos municípios, cabendo ao Estado apenas a realização de cursos de capacitação para professores, assim mesmo devendo ser desenvolvidos em parceria com os governos municipais.

Porém, tanto o Ministério Público Federal quanto a Procuradoria afirmaram que o governo do Estado do Amazonas não cumpriu suas obrigações relativas às metas inscritas no Plano Nacional de Educação.

Quanto ao quesito da participação para gestão e monitoramento de políticas públicas, constatou-se que os próprios governos negam estrutura de participação dos indígenas ou intervêm indevidamente em sua formação.

Assim sendo, apesar da educação indígena estar prevista em normas legais, não há condições para torná-la efetiva, principalmente diante de suas peculiaridades. Um exemplo disso é que o repasse de recursos a este tipo de educação é idêntico ao do ensino regular, no entanto, a adoção desses critérios não leva em consideração, na prática, as especificidades que essa modalidade de ensino requer. 


\subsection{O relatório de 2007 sobre a violação dos direitos educativos da Comunidade do Complexo do Alemão}

O presente tópico visa apresentar o material derivado da missão que se encarregou de acompanhar de perto a educação no Morro do Alemão, que foi encabeçada pela relatora Denise Carreira e sua assessora Suelaine Carneiro, socióloga, educadora e integrante da organização não governamental Gelédes Instituto da Mulher Negra, no período compreendido entre 8 e 11 de outubro de 2007, que analisa a precária situação vivenciada pela comunidade do Complexo do Alemão em relação à educação. Neste item serão apresentados os aspectos gerais contidos no relatório e, após, as observações específicas realizadas na missão sobre educação da Relatoria no Complexo do Alemão, Rio de Janeiro.

Vale ressaltar a importância deste tópico, que tratará a questão da violência e sua relação com a violação do direito humano à educação, em que a educação revela-se problemática quando está associada ao problema da insegurança em áreas conflagradas ${ }^{62}$. Trata-se de um bom exemplo, na prática, da importância da segurança para que a educação se realize, o que reforça veementemente a questão da indivisibilidade dos direitos humanos.

Por essa razão é que se justifica, cada vez mais, a necessidade de haver políticas públicas que dialoguem entre as diversas esferas de interesses sociais, pois somente através da integração entre os setores se torna possível a efetivação dos direitos humanos como um todo.

62 É nesse contexto que surgem, quase sempre, atitudes controladoras do Estado para evitar o desarranjo social, tais como o aumento de penas, o agravamento de problemas relativos aos sistemas carcerários, a cassação de direitos e garantias fundamentais, as práticas truculentas de segurança pública, dentre outros. (BITTAR, 2007).

Por essa razão, no mundo contemporâneo, os espaços urbanos foram tomados por populações atemorizadas que não crêem em outra forma de combater a violência a não ser violentamente, apontando para um futuro catastrófico para a vida nos centros urbanos, na medida em que existem possibilidades do cidadão ser violentado a qualquer tempo (ENDO, 2005). 


\subsubsection{Aspectos gerais da educação no relatório}

Tal missão servira para apurar a violação dos direitos educativos de crianças, jovens e adultos que frequentam as escolas públicas do Complexo do Alemão, a partir de denúncias de entidades locais recebidas pela Relatoria, e da forte divulgação pelos meios de comunicação. Percebe-se que esta missão em especial se encarregou de apontar a relação direta entre educação e segurança pública.

Para a realização desta missão e a elaboração do respectivo relatório, serviu-se da mesma premissa contida na observação 13 da Comissão DESC, de que para haver garantia ao direito à educação, é necessária a aplicação de quatro importantes características interligadas, quais sejam: disponibilidade (educação obrigatória e gratuita a todos); acessibilidade (programas educativos ao alcance de todos, sem distinção de qualquer ordem); aceitabilidade (programas educacionais adequados) e adaptabilidade (educação flexível às necessidades das comunidades em transformação). (RELATORIA NACIONAL PARA O DIREITO HUMANO À EDUCAÇÃO, 2007).

Para facilitar a visualização das diferentes etapas do trabalho desenvolvido nesta missão, este relatório foi dividido em cinco partes, compondo a seguinte estrutura: a) a educação como direito humano; b) contexto da missão; c) caracterização do complexo do Alemão; d) a missão da relatoria no complexo do Alemão; e) a educação e os novos conflitos armados. Além das partes apresentadas, ao final do relatório, encontram-se as recomendações ao Poder Público e aos organismos internacionais de direitos humanos para a construção de um plano de ação que invista em um novo tipo de relacionamento entre o Poder Público o os habitantes das favelas do Rio de Janeiro.

A primeira parte do relatório, que trata da questão da educação como direito humano, também descreve as características de universalidade, interdependência e indivisibilidade dessa esfera de direitos, além de sua exigibilidade face ao Estado por meios jurídicos e políticos.

Segundo dados do IBGE coletados entre os anos de 1996 e 2006 por meio da Pesquisa Nacional de Amostra por Domicílio (Pnad), dentre as dez regiões metropolitanas analisadas na pesquisa (Belém, Rio de Janeiro, Porto Alegre, São Paulo, Distrito Federal, Belo Horizonte, Curitiba, Salvador, Recife e Fortaleza), o Rio de Janeiro é a que possui a menor quantidade de matrículas no ensino fundamental. 
No entanto, vale ressaltar que uma das questões não evidenciadas pelas estatísticas é que o decréscimo geral das procuras pelo ensino fundamental ocorre devido ao fato de haver pessoas tendo menos filhos, o que afeta tanto a rede pública quanto a rede privada.

Além disso, o Rio de Janeiro está acima da média nacional quanto ao atraso escolar de mais de dois anos, apresentando índices próximos às principais cidades dos estados do Norte e Nordeste do Brasil.

De maneira geral, o Índice de Desenvolvimento da Educação Básica brasileiro é baixo, principalmente aquele referente à rede estadual, demonstrando um desempenho escolar baixo, e com isso, a péssima qualidade da educação brasileira. Por exemplo, a região metropolitana do Rio de Janeiro apresentou um índice para a $8^{\mathrm{a}}$ série da rede estadual preocupante, ficando à frente apenas de Recife. (RELATORIA NACIONAL PARA O DIREITO HUMANO À EDUCAÇÃO, 2007).

Com relação ao ensino médio, verifica-se que houve um crescimento geral no País ao seu acesso, no entanto, ainda existem muitos problemas associados a esta questão, como por exemplo, as altas taxas de evasão e a grande quantidade de alunos com atraso escolar. E no Rio de Janeiro, em especial, apesar de apresentar um crescimento nos últimos dez anos, este foi menor que a média de todas as outras regiões do País.

O crescimento no acesso a matrículas no ensino superior está ocorrendo em todas as regiões; no entanto, o Rio de Janeiro apresenta um ritmo inferior em relação à maioria das demais, exceto em relação a São Paulo e Porto Alegre. Nestes dois Estados, uma das prováveis hipóteses para haver um crescimento menor das matrículas se deve ao fato de já possuírem uma oferta suficiente, muito embora as estatísticas não se revelem claras nesse sentido.

No tópico referente à "descontinuidade, falta de profissionais da educação e violência”, relata-se que a análise de documentos provenientes da Comissão de Educação e Cultura da Câmara Municipal do Rio de Janeiro aponta outros graves problemas enfrentados pela cidade, como a falta de investimento na construção de novas unidades escolares. A falta de professores na rede estadual (déficit estimado de 22 mil professores) constitui outro sério problema, reflexo dos baixíssimos salários oferecidos.

Em 2006, o Ministério Público Estadual e o Sindicato Estadual dos Profissionais da Educação do Rio de Janeiro encaminharam à relatoria dos DhESCA um dossiê que fora entregue ao Ministério Público no final daquele mesmo ano, a respeito da violência presente nas escolas públicas do Rio de Janeiro. 
Este documento apresenta o relato do número cada vez maior dos casos de violência nas escolas públicas estaduais e municipais, que vão desde assaltos a alunos e educadores em geral até estupros e conflitos derivados do narcotráfico, além das péssimas condições de trabalho dos profissionais da educação. Já naquela ocasião, cobravam-se medidas urgentes do Poder Público para a solução destes gravíssimos problemas.

Vale ressaltar que no início de 2007, por iniciativa do segundo mandato do presidente Lula, foi lançado o Programa de Aceleração do Crescimento (PAC), visando a aumentar os investimentos de infraestrutura em transporte, energia, saneamento, habitação e recursos hídricos. (RELATORIA NACIONAL PARA O DIREITO HUMANO À EDUCAÇÃO, 2007).

Em agosto de 2007, o governo federal, por sua vez, lançou o PAC da Segurança Pública, também conhecido como Programa Nacional de Segurança Pública com Cidadania (Pronasci), cujo objetivo era promover ações visando à prevenção, controle e repressão da criminalidade, atuando em suas raízes socioculturais, a fim de gerar uma mudança no estigma da segurança pública no País. Este programa foi desenvolvido para atender, inicialmente, as 11 regiões metropolitanas mais violentas, como São Paulo, Rio de Janeiro, Belo Horizonte, Brasília, Recife, entre outras.

O órgão responsável por este programa é o Ministério da Justiça, que procurou mudar o âmbito de ação para o combate à criminalidade em razão da forte presença do crime organizado em áreas de baixa renda das grandes cidades brasileiras, principalmente as favelas, da ineficácia do sistema de ressocialização de presos e do aumento de jovens envolvidos com crimes.

As principais frentes de atuação do programa consistem na valorização dos agentes de segurança pública, a reforma do sistema penitenciário, o combate à corrupção policial e o desenvolvimento de ações socioeducativas que garantam a inclusão da comunidade, especialmente a educação.

Quanto à educação, o programa prevê um incentivo à qualificação dos policiais, através da concessão de bolsa-auxílio aos que participarem de cursos de extensão ou de pós-graduação. Além disso, existem também para os jovens os projetos Brasil Alfabetizado, Programa de Educação Profissional para Jovens e Adultos (Proeja), além de cursos preparatórios para o Exame Nacional do Ensino Médio (Enem).

Para a jovem população carcerária, continuará havendo a alfabetização por meio do programa denominado Brasil Alfabetizado, além da implantação do Programa Nacional de 
Inclusão de Jovens (ProJovem) e a preparação para o Enem, com vistas ao acesso à universidade pelo ProUni ou pelo programa Universidade Aberta.

Uma das primeiras regiões a ser considerada pelo denominado PAC das favelas foi o Complexo do Alemão, prevendo a construção de escolas, postos de saúde, obras de infraestrutura e saneamento. No entanto, o início dessas obras acirrou os conflitos entre os narcotraficantes, segundo noticiado pela imprensa no ano de 2008.

Dentro do município do Rio de Janeiro, existem sérias desigualdades educacionais, resultantes da precariedade e do descaso existentes entre as diversas regiões do Município. Um exemplo disso foi a falta de dados da região do Complexo do Alemão que ocasionou a sua exclusão de uma pesquisa importante sobre a situação da educação nas 33 regiões administrativas do município do Rio de Janeiro.

O estudo de caso foi feito no Complexo do Alemão. Este é formado por um conjunto de favelas localizado na zona norte da cidade do Rio de Janeiro, marcado pelas tensões e constantes embates entre a força policial e o narcotráfico, principalmente os ocorridos entre os meses de maio e julho de 2007, que afetaram diretamente o serviço educacional daquela região.

Foram grandes os impactos sentidos por aquela comunidade, como o fechamento de escolas e creches, a diminuição da jornada escolar das unidades que continuaram prestando atendimento, o impedimento do exercício dos profissionais da educação, além do risco de vida e piora nas precárias condições de subsistência de seus habitantes. (RELATORIA NACIONAL PARA O DIREITO HUMANO À EDUCAÇÃO, 2007).

Vale ressaltar que os relatos feitos pelas autoridades públicas, pelos membros daquela comunidade, pelos profissionais da educação e pelos integrantes de organizações da sociedade civil foram no sentido de que o problema da violência nas escolas é permanente, e não esporádico, tendo como exemplo do ápice desses conflitos a grande intervenção policial realizada no mês de maio de 2007, resultante da guerra constante entre os policiais e os diferentes grupos de narcotraficantes e seus líderes.

Assim sendo, apesar de ser dever do Estado a retomada de sua autoridade naquele local para a manutenção da ordem pública, os meios utilizados para tanto têm se baseado em formas preocupantes de atuação, além de duvidosas quanto à sua eficácia.

Além disso, até então, não existiam estratégias conjuntas entre as esferas de governo (federal, estadual e municipal) e suas respectivas áreas de atuação em parcerias administrativas e sociais que assegurassem a proteção aos direitos humanos daqueles moradores, mostrando-se incapazes de combater as causas determinantes de tais conflitos. 
Isso resulta na revelação deturpada do Estado contra os seus próprios interesses, voltandose contra a população de baixa renda com todas as formas de violência e repressão, ao invés de adotarem alguma forma de proteção ou minimização dos danos sofridos por ela.

Outra preocupante constatação feita pela Relatoria fora a inversão da lógica das medidas adotadas pelas autoridades públicas, notando-se primeiramente uma preocupação com a destruição das redes criminais, para, em seguida, reforçar-se a imagem das obras de infraestrutura do governo, como o Programa de Aceleração do Crescimento (PAC); apenas por último, percebe-se a menção à implementação de serviços e políticas sociais adequadas.

Assim sendo, apesar de haver alguma atuação nas políticas de segurança pública, tanto no Estado do Rio de Janeiro quanto no País como um todo, naquele momento em que se situa o relatório, o esforço das autoridades públicas neste sentido ainda era inexpressivo, mostrando-se ineficaz quanto ao seu resultado, na medida em que não compreendia uma mudança efetiva na priorização das necessidades do País.

Para a viabilização de tais programas e a garantia de sua legitimidade, tornava-se imprescindível a atuação conjunta, de maneira ativa e efetiva entre as esferas de governo e o público-alvo destas políticas nos seus processos de decisão, garantindo a participação e vinculação constante dos principais interessados, para além da mera consulta informal.

Com esta missão da Relatoria, concluiu-se que o Estado brasileiro, por meio de suas três esferas de governo, violava reiteradamente o direito humano à educação, além dos demais direitos dos moradores do Complexo do Alemão e áreas equivalentes, tanto pela ação - práticas de segurança pública truculentas e de cunho militar - quanto pela omissão - ausência de políticas educacionais e sociais voltadas àquela e outras comunidades.

Dentro do entendimento de que a educação no Complexo do Alemão encontrava-se em situação de emergência, agravada pelos "conflitos armados" vivenciados no cotidiano de seus moradores, a Relatoria apresentou um conjunto de recomendações visando à aplicação imediata da legislação internacional de direitos humanos, além da utilização do documento internacional intitulado "Requisitos Mínimos para a Educação em Situação de Emergência, Crises Crônicas e Reconstrução"63, elaborado pela Rede Interinstitucional para a Educação

63 A edição em Língua Portuguesa deste documento intitulada Requisitos Mínimos para a Educação em Situação de Emergência, Crises Crónicas e Reconstrução foi publicada em 2006 pela Escola Superior de Educação - Instituto Politécnico de Viana do Castelo, Avenida Capitão Gaspar de Castro, Apartado 513, 4900-908 Viana do Castelo, Portugal, podendo ser encontrada no seguinte endereço eletrônico: <http://www.ineesite.org/minimum_standards/INEE_MSEE_PT.pdf >. É uma tradução da versão original 
em Situação de Emergência ${ }^{64}$, como ponto de partida para a construção e a implementação de estratégias para se garantir a educação em áreas de conflito armado. (RELATORIA NACIONAL PARA O DIREITO HUMANO À EDUCAÇÃO, 2007).

\subsubsection{Aspectos específicos sobre o trabalho de campo}

Especificamente em relação à educação, dos 72 mil habitantes do Complexo do Alemão considerados pela Secretaria Estadual, 7.823 não possuem atendimento. Além disso, dados de pesquisa realizada pelo Centro de Promoção da Saúde e o Unicef demonstraram que a própria comunidade considera o ensino de escola pública de baixa qualidade. Nesse quadro, a violência é o principal fator apontado pelo prejuízo na aprendizagem, fazendo com que haja a perda dos dias letivos e a dificuldade de acesso às unidades escolares. (RELATORIA NACIONAL PARA O DIREITO HUMANO À EDUCAÇÃO, 2007).

Devido à megaoperação policial realizada no Complexo do Alemão contra as lideranças do narcotráfico, as oito escolas e creches municipais da região suspenderam o atendimento do dia 2 de maio de 2007 até o dia 30 de julho, prejudicando 5.750 estudantes.

Visando diminuir esses prejuízos, a Secretaria Municipal estabeleceu um atendimento alternativo emergencial durante os conflitos, por meio de atendimentos com duração de duas horas no Ciep Gregório de Matos, localizado nos arredores daquela comunidade; no entanto, o medo afastou muitos estudantes deste Projeto.

O grande objetivo desta missão da Relatoria foi apurar o ocorrido antes, durante e após a suspensão das aulas, e a situação do atendimento educacional na área, a fim de se avaliar se

em Língua Inglesa, com o título Minimum Standards for Education in Emergencies, Chronic Crises and Early Reconstruction, edição da INEE publicada em 2004 com o ISBN 1-58030-C34-0. (REQUISITOS..., 2006).

64 “A Rede Interinstitucional para a Educação em Situação de Emergência é uma rede aberta composta por agências das NU (Nações Unidas), ONGs (Organizações não governamentais), doadores, profissionais, investigadores e pessoas das populações afectadas, trabalhando em conjunto para assegurar o direito à educação em situações de emergência e reconstrução pós-crise. A INEE (sigla em inglês) foi formada no ano 2000 durante o Fórum Mundial de Educação em Dakar na sessão estratégica de educação em situação de emergência (World Education Forum's Strategy Session on Education in Emergencies in Dakar), durante o qual a ideia foi proposta para desenvolver um processo que melhorasse as comunicações e a colaboração interagências dentro do contexto de educação em situação de emergência. No seguimento da consulta inter-agências em Genebra no ano 2000, a INEE foi oficialmente criada para construir e consolidar as redes existentes. O propósito dessa Rede Inter-Institucional para a Educação em Situação de Emergência é servir como uma rede aberta e global de membros que trabalham em conjunto num enquadramento humanitário e de desenvolvimento para garantir que todas as pessoas têm direito a uma educação de qualidade e um ambiente de aprendizagem seguro em situações de emergência e reconstrução pós-crise.” (INTER-AGENCY, 2011). 
as violações ao direito humano à educação se limitaram ao período da megaoperação policial contra o tráfico, ou se era uma situação constante vivenciada pelos moradores do Complexo do Alemão.

Para tanto, a missão envolveu visitas às escolas do local, onde foram entrevistados moradores, profissionais da educação, membros de entidades do terceiro setor, além de integrantes do Executivo, Legislativo e Judiciário.

Na maioria dos relatos feitos pelos profissionais da educação das escolas sediadas no Complexo do Alemão, a escola ainda tem um significado positivo para os alunos, para as famílias e até mesmo para os narcotraficantes, pois é considerado ainda o único órgão público procurado pelas pessoas que buscam algum tipo de apoio e informação.

Assim, para a maioria dos educadores, as escolas ali sediadas formam um "núcleo de resistência", significando uma aposta num futuro um pouco melhor para aqueles alunos.

Outra reclamação recorrente naquela comunidade é a de que os policiais não fazem qualquer diferenciação entre os bandidos e os demais moradores, ainda que não envolvidos com o tráfico. Por essa razão é que os direitos humanos em geral são violados, principalmente o direito à vida, em decorrência da matança generalizada.

A falta de professores é um problema típico daquela localidade, devido aos baixos salários e aos grandes riscos trazidos pela violência. Para a maioria dos professores entrevistados, o Estado, diante de comunidades pobres, atua apenas como uma força repressora da lei, que se utiliza apenas da força armada para as situações de conflito.

Além disso, o sistema criado pelo Estado referente à aprovação automática representa uma benesse apenas para as estatísticas do País, prejudicando sobremaneira o futuro escolar dos alunos, que passam de ano sem a menor condição de aprendizado, e muitas vezes sequer sem ter comparecido a alguma das aulas ministradas.

Analisando-se o discurso da secretária municipal de educação da época, Sonia Mograbi, percebe-se uma grande contradição em relação à realidade vivida por todos os moradores e profissionais daquela região. Em determinado momento, afirmou até não ser papel da Secretaria de Educação tratar da segurança escolar, sendo esta uma preocupação cabível a outros órgãos do governo. Além disso, posicionou-se contra políticas especiais que enfrentem as desigualdades no acesso e na qualidade de ensino para os alunos das favelas, sob o pretexto de acirrar a discriminação entre eles. (RELATORIA NACIONAL PARA O DIREITO HUMANO À EDUCAÇÃO, 2007).

No entanto, na visão de vários representantes de organizações civis, o questionamento à violação dos direitos educativos significou uma nova perspectiva sobre 
as tensas relações entre políticas de segurança pública e políticas sociais diante das populações de favelas.

Um dos problemas relatados pelo sindicato dos educadores é que o Ministério Público não possui uma atuação significativa diante das graves denúncias feitas em relação à falta de atendimento escolar para quase todas as comunidades das favelas, na medida em que não fazem prosperar as denúncias levadas pelo sindicato.

No final da missão da relatoria, foi realizada audiência pública com a presença de Denise Carreira, relatora nacional para o direito humano à educação, políticos, representantes administrativos ligados à educação, representantes do Ministério Público estadual, além da presença de diversos líderes comunitários e representantes de associações de moradores daquelas comunidades.

Dentre as mais urgentes recomendações daquela relatoria, citam-se as seguintes: a implementação de uma dinâmica que permita a troca de informações entre as diversas áreas sociais; a integração entre as políticas sociais e de segurança pública visando ao respeito e à não violação dos direitos humanos das comunidades; a criação de meios institucionais para a promoção da participação das comunidades, visando ao desenvolvimento de ações nas áreas, principalmente aquelas que dizem respeito ao Programa de Aceleração do Crescimento (PAC) do governo e a criação de regulamentos que garantam a segurança dos alunos em caso de conflito armado.

Ainda naquela audiência, após as manifestações dos moradores das comunidades trazendo inúmeras denúncias quanto à violação dos direitos humanos por parte dos agentes do Estado e dos narcotraficantes, as propostas surgidas foram organizadas em blocos, considerando-se:

a) a violação dos direitos humanos pelo uso da força policial durante as diligências feitas nas comunidades, igualando-se todos, sem exceção, à condição de bandidos, citando-se a ocorrência de abuso de autoridade, invasões de domicílio, prisões e constrangimento ilegais, truculência, dor física e moral;

b) a violação aos direitos educativos da criança e do adolescente, tanto por parte do Estado, no que diz respeito às suas políticas sociais, quanto pela atuação da força policial durante as diligências no combate ao tráfico. Nesse sentido, a omissão do Estado é patente, pois ao invés de garantir a segurança dos alunos, o Estado apenas delibera acerca do fechamento das escolas. Diante desta guerra de forças, o Estado sempre sucumbe ao tráfico, sendo que os jovens em geral são transferidos para outras escolas fora de suas comunidades, correndo sérios riscos de vida, pois vários 
deles são mortos pelos policiais durante este trajeto, confundidos com os criminosos;

c) a obscuridade das intenções do PAC, uma vez que representa, para a comunidade, um programa imposto "de cima para baixo", ou seja, sem a participação da comunidade. Existem sérias desconfianças de que este programa foi implementado para remover parte da população para outras localidades, e que suas obras sirvam apenas para facilitar a atuação da polícia, desatendendo os interesses primordiais dos habitantes daquelas comunidades;

d) as propostas apresentadas pelos moradores da comunidade, no sentido da criação de políticas públicas preventivas para a redução da violência nas comunidades; o melhor treinamento e preparo dos policiais durante as diligências efetuadas nas comunidades para o combate ao tráfico; a participação efetiva da sociedade civil nas políticas a serem desenvolvidas entre os diversos setores e órgãos públicos; a participação ativa dos integrantes das comunidades no desenvolvimento do PAC.

Houve a entrega, por parte da representante da ONG Nascimento para o Bem, de um documento contendo nove propostas de inclusão social para as comunidades locais, a serem implementadas pelo PAC. (RELATORIA NACIONAL PARA O DIREITO HUMANO À EDUCAÇÃO, 2007).

Após solicitação formal da Relatoria, o Ministério Público Estadual apresentou pedido de informações junto às secretarias municipal e estadual de Educação sobre a situação enfrentada pela educação no Complexo do Alemão. Como resultado destes pedidos, houve apenas um respondente, qual seja, a Secretaria Municipal de Educação.

Além disso, a Relatoria recebeu cópia de processos em que foram denunciados casos de violência na escola apresentados pelo Sindicato Estadual dos Profissionais da Educação no Rio de Janeiro, bem como vários outros relatos referentes à violência em geral praticada contra os moradores daquela localidade, durante a operação policial de combate ao tráfico.

Com base na Declaração de Genebra sobre Violência Armada e Desenvolvimento, de 2006, a Relatoria concluiu tratar-se de violência armada a situação das favelas cariocas em geral. Trata-se de caso classificado como "emergência complexa", por se caracterizar como situação de gravidade social gerada pelos seres humanos, como é o caso dos conflitos armados.

Isso porque envolve frequentes embates entre traficantes de drogas e forças de segurança, gerando dor, mortes de civis e diversas violações de direitos humanos, dentre eles, o direito à educação, não havendo previsão de término desta situação, pois a orientação que se 
tem é que esses confrontos persistam até o aniquilamento completo das estruturas do crime organizado.

Para a Relatoria, impõe-se a restauração da autoridade do Estado frente ao Complexo do Alemão e outras comunidades cariocas dominadas pelo tráfico. No entanto, para que haja a recuperação desta autoridade, questiona-se a fórmula atual para o enfrentamento deste problema, calcado no uso arbitrário e excessivo da força, gerando continuamente a violência. (RELATORIA NACIONAL PARA O DIREITO HUMANO À EDUCAÇÃO, 2007).

Analisando-se a situação do Estado frente a esta dinâmica, percebe-se nitidamente a sua fragilidade, ao apresentarem as autoridades públicas um conhecimento limitado sobre o funcionamento do poder entre as redes do narcotráfico, traduzindo-se no preconceito contra a própria comunidade em geral, vítima da situação imposta pelos bandidos; a falta de estratégias veiculadas entre os diversos órgãos do governo para garantir os direitos humanos das comunidades, voltando-se o próprio Estado brasileiro de forma dura e violenta contra a parcela de baixa renda de sua população; a falta de segurança para a proteção das comunidades expostas à violência; a presença da violência e da barbárie instituída contra os habitantes daquelas comunidades por parte da polícia e das forças de segurança nacional; a garantia de serviços sociais adequados aparece sempre como último dever e etapa a ser cumprida diante do enfrentamento das situações de caos e emergência, priorizando-se as grandes operações policiais e o derramamento de sangue à implantação de políticas públicas sérias e efetivas.

Ressalta-se também a falta de planejamento entre as esferas de governo visando à minimização dos impactos sofridos pela violência em relação aos direitos educativos.

A única iniciativa em matéria de direitos educativos veio por parte da Secretaria Municipal de Educação, que, no auge dos conflitos travados no ano de 2007, procurou oferecer condições mínimas de atendimento escolar para quase quatro mil crianças e jovens que tiveram suas aulas paralisadas depois de quase dois meses: os jovens frequentaram jornada escolar reduzida de duas horas por dia numa precária estrutura estadual.

De acordo com a Observação n. ${ }^{\circ} 13$ do Comitê Desc, que dispõe sobre a aplicação do artigo 13 do Pidesc, o direito à educação se efetiva por meio de quatro elementos interrelacionados: disponibilidade, acessibilidade, aceitabilidade e adaptabilidade.

Analisando-se esses quatro elementos de efetivação do direito à educação, percebe-se que: 
a) quanto à disponibilidade (educação disponível a todos, sem exceção): as escolas não conseguem oferecer atendimento adequado devido às precárias condições que vão desde os baixíssimos salários dos profissionais e insuficiência de recursos nas escolas até a violência cotidiana, que impede a frequência dos alunos às aulas;

b) quanto à acessibilidade (a presença de todos, sem exceção, na educação pública, sem qualquer tipo de discriminação): além da falta de professores, o governo segrega a comunidade do Complexo do Alemão em relação à outras, pois os serviços ali oferecidos possuem qualidade mais baixa se comparados a outras regiões do Rio de Janeiro, de acordo com a pesquisa realizada pela organização da sociedade civil "Rio Como Vamos";

c) quanto à aceitabilidade: a educação oferecida deve se comprometer com a qualificação dos educadores e demais profissionais, e condizente com a qualidade da educação pública prevista em métodos e programas de ensino público, o que não ocorre naquela localidade, em que o Estado não oferece os padrões mínimos previstos no artigo 206 da Constituição Federal e no artigo $4^{\circ}$ da Lei de Diretrizes e Bases da Educação Nacional;

d) quanto à adaptabilidade: refere-se ao respeito à raça, religião, costumes e cultura dos estudantes em geral.

Conforme constatações de pesquisas realizadas pelo IBGE, apesar de ser uma região onde predomina a população negra (preta e parda), praticamente inexistem iniciativas vinculadas à alteração da LDB pela Lei n. ${ }^{\circ}$ 10.639/03, que tornou obrigatório o ensino e a cultura africana e afro-brasileira na educação básica de todo o País.

Portanto, de acordo com todas as observações realizadas durante a missão da Relatoria, concluiu-se que o Estado brasileiro, em todos os seus âmbitos (federal, estadual e municipal), viola o direito humano à educação das comunidades cariocas, em especial a do Complexo do Alemão, devido à falta de garantia de condições mínimas para a efetivação deste direito.

Com isso, urge que a educação naquela localidade seja tratada como uma situação de emergência e de vulnerabilidade extrema sofrida pela comunidade, principalmente em decorrência da violência permanente sofrida por seus habitantes, mas também devido à falta de estrutura e investimento social para garantir uma educação de qualidade que garanta os padrões mínimos previstos em lei.

Diante de todos os problemas apresentados, verifica-se a necessidade urgente de: implantação de um plano de ação com vistas à garantia do direito humano à educação de 
qualidade, baseada no documento em que se expõem os "Requisitos Mínimos para a Educação em Situação de Emergência"; presença de operadores de direito, por meio da instalação de postos de atendimento do Ministério Público Estadual e Federal e da Defensoria Pública àquela comunidade, bem como visitas constantes dos organismos da ONU, Cruz Vermelha, OAB e outros, a fim de se amenizar as situações de abusos de poder por parte da polícia; restauração de serviços básicos como água, luz, correio e telefone aos habitantes do Complexo e seu entorno; informações fidedignas e de qualidade, pois os dados numéricos e estatísticos apresentados pelo poder público, relativos àquela região, mostram-se, muitas vezes, insuficientes e contraditórios (para tanto, tais informações devem, inclusive, estar disponíveis para consulta pública, garantindo a transparência das informações públicas); articulação e coordenação entre as políticas de segurança e as políticas sociais em todas as esferas de governo visando à proteção das comunidades escolares; participação comunitária efetiva, que garanta sua contribuição no processo de tomada de decisões, levando-se em conta toda a diversidade existente entre as organizações comunitárias, e não reduzindo este processo a alguns denominados "aliados" do governo (as obras do PAC, por exemplo, deveriam se realizar através do diálogo permanente com a comunidade, de maneira organizada e institucionalizada); garantia de mecanismos de segurança escolar, para que haja preparo tanto por parte dos policiais como por parte da comunidade no caso de ocorrência de conflitos; criação de um cadastro para se garantir a oferta de educação em todos os níveis aos habitantes do Complexo do Alemão e proximidades, num primeiro momento, estendendo-se posteriormente a toda a cidade do Rio de Janeiro.

Após nove meses da missão realizada em outubro de 2007 no Complexo do Alemão, a equipe da Relatoria Nacional para o Direito Humano à Educação retornou ao Rio de Janeiro por mais duas vezes, nos períodos compreendidos entre 8 e 9 de agosto e 29 e 30 de setembro de 2008 (PLATAFORMA BRASILEIRA DE DIREITOS HUMANOS ECONÔMICOS, SOCIAIS, CULTURAIS E AMBIENTAIS, 2008).

Um dos objetivos das novas diligências foi realizar a entrega oficial do relatório da missão de 2007 às autoridades públicas e à direção das escolas visitadas durante a missão, visando à demonstração dos resultados aos moradores daquela região e, em seguida, o previsto encaminhamento do mesmo documento à Comissão Interamericana da OEA e ao Comitê da Criança da ONU.

No entanto, o principal objetivo do retorno foi averiguar a situação daquela localidade após decorridos nove meses da missão realizada pela Relatoria. Com este 
retorno, foi possível ouvir novamente a direção escolar, os moradores e representantes de órgãos públicos sobre eventuais mudanças e/ou impactos ali sentidos.

Com base nessas novas oitivas, a Relatoria pôde concluir que nesse período houve uma diminuição dos confrontos armados entre policiais e traficantes, mas não houve mudanças significativas quanto ao enfrentamento dos problemas relativos à educação daquela comunidade.

No entanto, algumas medidas começaram a ser tomadas com relação à receptividade das recomendações da Relatoria pelas autoridades estaduais quanto à urgência da elaboração de estratégias e protocolos formais destinados às escolas sobre como se preparar para enfrentar os confrontos armados.

Uma das medidas adotadas pela Secretaria de Segurança Pública para evitar pânico entre estudantes, familiares e profissionais ligados à educação foi não mais permitir a entrada do veículo blindado denominado "Caveirão" no início e fim dos períodos escolares.

Além disso, algumas organizações da sociedade civil e organismos internacionais estão discutindo a possibilidade da construção de um cadastro para viabilizar-se a questão da necessidade de abertura de vagas escolares em todos os níveis, de modo a funcionar como elemento de pressão social e política por direito à educação em comunidades populares.

Quanto ao PAC, a Relatoria concluiu que, apesar de representar um avanço quanto ao diálogo entre os entes federados e a ação do poder público perante as comunidades, ainda não existe uma estratégia una para a atuação do Estado brasileiro em situações de conflitos armados.

Essas zonas de conflito ora são tratadas pelo poder público com especificidade quanto à atuação da segurança pública, ora são tratadas iguais a todas as outras comunidades quanto aos seus direitos sociais. Portanto, o que ocorre em geral é o uso contínuo da força e a ausência de articulação de quaisquer políticas sociais que favoreçam tais comunidades.

Portanto, o discurso da universalidade e não especificação das áreas mais carentes de políticas sociais contribui para a não formulação de políticas de "discriminação positiva", com vistas a suprir as enormes desigualdades entre os sistemas educacionais das áreas afetadas pela desastrosa combinação entre profunda exclusão social e violência armada. 
Isso porque, conforme mencionado anteriormente, as situações que envolvem os conflitos armados demandam planos de ação governamental específicos para o combate de tal agravante à situação de suprimento das deficiências sociais.

Quanto ao PAC das favelas, a Relatoria entendeu ser urgente e necessária a participação comunitária efetiva como garantia da transparência das atividades do governo e da concreta proteção aos direitos dos moradores daquelas comunidades.

O próprio secretário da segurança pública da época, José Mariano Beltrame, reconheceu que as recorrentes violações aos direitos humanos estão anteriormente ligadas à falta de estrutura social, principalmente no que diz respeito à educação e à saúde, representando a falta de segurança apenas uma parte desses problemas.

No entanto, informou à Relatoria que aquela Secretaria estava desenvolvendo curso de formação de policiais, a fim de se obter uma maior proximidade deles perante a comunidade.

Já a Secretaria Estadual de Educação, naquela oportunidade, informou à Relatoria que estão pesquisando sobre a possibilidade de implantação de uma política de valorização de profissionais que atuam em áreas de risco, assim consideradas aquelas em relação à violência.

Além disso, anunciou à Relatoria algumas medidas que estavam sendo tomadas em relação ao acesso e à qualidade do ensino na rede estadual, bem como medidas para tentar suprir o déficit em relação à rotatividade e ausência de professores.

Por outro lado, o Ministério Público nega os avanços relatados pelo secretário da segurança pública de 2007 a 2008, afirmando que o discurso vigente para a atuação da polícia continua sendo repressivo, predominando a violência e o desrespeito à vida.

Apesar de o Ministério Público afirmar que passou a monitorar as ações no Complexo do Alemão, este acompanhamento não é feito de perto, devido à existência de regras internas de segurança daquela Instituição que não recomendam a entrada naquela localidade.

Apresentado o relatório pela Relatora nacional para diversas lideranças comunitárias do Rio de Janeiro, reiterou-se o fato de que as obras do PAC não vieram acompanhadas de uma participação efetiva da comunidade. No entanto, a falta de diálogo e nitidez das intenções deste projeto gera o receio por parte da comunidade de que o Estado descumpra o que foi acordado com o governo federal (PLATAFORMA BRASILEIRA DE DIREITOS HUMANOS ECONÔMICOS, SOCIAIS, CULTURAIS E AMBIENTAIS, 2008). 
A comunidade em geral e as escolas relataram uma diminuição dos confrontos entre policiais e narcotraficantes; no entanto, para muitos, o clima ainda é de temor e expectativa, além dos demais problemas educacionais que ora permanecem. As lideranças comunitárias, por sua vez, também defendem a necessidade de participação efetiva das comunidades populares nas obras do PAC.

Concluído o relatório, este foi entregue às autoridades públicas, às organizações locais ali situadas, às entidades da sociedade civil daquele Estado e do país, ao relator especial da ONU para o direito humano à educação da época (Vernor Muñoz), à Comissão Interamericana da Organização dos Estados Americanos (OEA) e ao Comitê dos Direitos da Criança da ONU para a adoção de medidas pertinentes, conforme o estabelecido nos instrumentos internacionais de proteção dos direitos humanos.

\subsection{O relatório sobre a educação nas prisões brasileiras}

Visando a constatar o respeito à garantia do direito à educação nas prisões brasileiras e contribuir para o debate público sobre a apreciação da proposta de Diretrizes Nacionais de Educação no Sistema Prisional pelo governo e dos projetos de lei sobre remição da pena por estudo que tramitavam no Congresso Nacional, foi realizada missão pela Relatoria Nacional para o Direito Humano à Educação, no período compreendido entre outubro de 2008 e abril de 2009 (RELATORIA NACIONAL PARA O DIREITO HUMANO À EDUCAÇÃO, 2009).

Essa missão, composta pela relatora nacional para o direito humano à educação, Denise Carreira - com uma trajetória de mais de vinte anos na luta em defesa dos direitos humanos -, e a assessora Suelaine Carneiro, socióloga e educadora, derivou-se de trabalho anterior desenvolvido pela ex-relatora de educação, Edla Soares, e sua assessora, Ednar Cavalcanti, cujo mandato se deu entre os anos de 2006 e 2007, realizando um levantamento da situação educacional nas unidades prisionais femininas de Pernambuco.

Complementando o trabalho anterior, esta Relatoria organizou o processo de missão de seguimento a Pernambuco, realizando visitas a unidades prisionais ali localizadas, além dos Estados do Pará, Rio Grande do Sul, São Paulo e Distrito Federal, totalizando onze (11) unidades, incluindo-se as masculinas, e entrevistando-se detentos, 
diretores das unidades, agentes penitenciários e representantes da sociedade civil organizada, num total de mais de duzentas (200) entrevistas.

Para a realização das diversas constatações e análises, o relatório apresenta dados gerais sobre educação nas prisões e levantamentos realizados na missão sobre educação em várias unidades prisionais localizadas nos referidos estados brasileiros.

A importância deste tópico está associada à questão do tratamento e concepção reservados à educação, principal preocupação apontada na proposta de pesquisa desta dissertação de mestrado. No caso das prisões, conforme relatado pela missão, ela é vista como um favor ou mera concessão aos mesmos, distanciando-se do conceito de educação como um direito inerente a todo ser humano. A partir deste ponto de vista, a educação passa a ser objeto de barganha utilizado pelos agentes penitenciários para a exigência da manutenção da ordem disciplinar dos detentos.

Há outra distorção conceitual em relação à obrigatoriedade da atuação da sociedade civil no controle e fiscalização da parte social relativa ao sistema prisional. Para os gestores desse sistema, ao contrário, a sociedade civil possui uma atuação e importância reduzida, na medida em que é vista como mera colaboradora neste processo.

Constata-se também que há um constante conflito entre a garantia do direito à educação e o modelo de sistema prisional atual, palco de grandes violações de direitos humanos, marcados pela superlotação dos presídios e forte truculência presente nos procedimentos de segurança e medidas disciplinares.

Demonstra-se, com a presente análise, a falência total do sistema prisional do Estado, incapaz de ressocializar o indivíduo, devido à violência empregada e condições desumanas de permanência aos detentos. Trata-se de responsabilidade que deve ser atribuída a todos os cidadãos, seguindo a premissa de que a violação a um direito humano significa a violação a um direito pertencente e afeto a todo o planeta.

Para tanto, ressalta-se, mais uma vez, a indissociabilidade dos direitos humanos, pois para que a educação entre os encarcerados seja efetiva, ainda que haja a sua oferta, é necessário que a mesma caminhe pari passu com o atendimento aos demais direitos básicos e fundamentais que lhes são inerentes, permitindo-se o diálogo permanente entre os entes do governo e a administração em geral e todos os setores da sociedade civil.

Em contrapartida, notam-se alguns avanços no que diz respeito às pressões realizadas pela própria Relatoria e demais organizações da sociedade civil em favor da educação para os detentos, devido ao fato de que fora modificada a lei de execução penal 
para garantir ao preso remição de pena por estudo, o que antes somente era possível mediante trabalho.

\subsubsection{Aspectos gerais da educação no relatório}

Com relação ao atendimento educacional nas unidades, tem-se: a descontinuidade em razão de motins, revistas (blitz) e demais procedimentos de segurança; baixa oferta em relação à demanda, com esta atingindo níveis mínimos que giram em torno de $10 \%$ a $20 \%$ dos detentos de todas as unidades pesquisadas, apesar do grande interesse apresentado pelos mesmos; a falta de qualidade naquelas unidades onde há atendimento educacional, representada pelos turnos reduzidos, ausência de projeto pedagógico e materiais didáticos, infraestrutura precária e carência de educadores em geral.

Nesse sentido, a Relatoria posiciona-se a favor do combate efetivo à impunidade referente aos crimes cometidos contra a sociedade e contra o Estado, mas, por outro lado, questiona o modelo de punição baseado exclusivamente no encarceramento de pessoas como resposta ao crescimento do crime organizado em geral.

Analisando-se minuciosamente a situação do direito à educação nessas condições de encarceramento, a Relatoria Nacional apresentou um levantamento envolvendo nove (9) recomendações estruturais e quatorze (14) recomendações complementares visando a garantir melhores condições para a efetivação do direito humano à educação nas penitenciárias do País.

No entanto, essas medidas apresentadas correspondem a atitudes mínimas e concretas para atender apenas o que está previsto nas leis nacionais e normas internacionais que representam compromisso firmado pelo Brasil.

Para a divulgação e cumprimento de tais medidas, a missão destinou o referido Relatório ao conhecimento das autoridades públicas federais e estaduais, além de organizações da sociedade civil referentes à proteção da educação e demais direitos humanos e também à população brasileira em geral.

Do ponto de vista da proteção internacional a esse direito, o Relatório também foi destinado ao relator especial da ONU para o Direito Humano à Educação, Vernor Muñoz, ao Conselho de Direitos Humanos e ao Subcomitê de Prevenção da Tortura e outros Tratamentos Cruéis, Desumanos e Degradantes da ONU. 
Em todas as etapas desta missão, procurou-se fazer um levantamento das informações baseando-se nos seguintes elementos de pesquisa:

a) atendimento educacional oferecido diante das desigualdades de gênero, raça, deficiências, orientação sexual etc.;

b) gestão;

c) participação da sociedade civil e ativistas sociais;

d) relação da educação com o acesso ao trabalho, saúde e outros direitos sociais;

e) o papel do Judiciário, especialmente o Ministério Público e as Varas de Execução Penal.

Além das normas nacionais anteriormente citadas referentes ao direito à educação, a Relatoria considerou para a elaboração do Relatório sobre educação nas prisões brasileiras um documento internacional específico sobre o acesso à educação de pessoas encarceradas, denominado Regras Mínimas para o Tratamento de Prisioneiros, aprovado pelo Conselho Econômico e Social da ONU em 1957. Além disso, para a elaboração deste relatório, levou-se em conta também toda a legislação nacional e internacional sobre educação nas prisões.

De acordo com o documento Regras Mínimas:

[...] devem ser tomadas medidas no sentido de melhorar a educação de todos os reclusos, incluindo instrução religiosa. A educação de analfabetos e jovens reclusos deve estar integrada no sistema educacional do país, para que depois da sua libertação possam continuar, sem dificuldades, a sua formação. Devem ser proporcionadas atividades de recreio e culturais em todos os estabelecimentos penitenciários em benefício da saúde mental e física. (RELATORIA NACIONAL PARA O DIREITO HUMANO À EDUCAÇÃO, 2009).

Segundo pesquisa específica realizada por Mariângela Graciano (2005), este documento possui alguns obstáculos ao reconhecimento do direito humano à educação aos detentos, quais sejam: indistinção entre educação formal, ensino religioso e educação não formal; restrição quanto à obrigatoriedade do Estado em oferecer educação apenas em relação à alfabetização; a integração da educação penitenciária ao sistema regular de ensino de maneira facultativa. Apesar de tais limitações, citam-se alguns importantes aspectos do documento, tais como a possibilidade do atendimento de creche dentro da unidade prisional e a oferta de educação física.

A partir disso, surgiu a Resolução n. ${ }^{\circ} 14$ do Conselho Nacional de Políticas Criminal e Penitenciária, datada de 11 de novembro de 1994, dispondo sobre a adaptação e 
consequente aplicação no Brasil da norma internacional para o tratamento das pessoas encarceradas.

Na legislação nacional, a educação nas prisões é classificada como educação de jovens e adultos. Pela Lei de Diretrizes e Bases da Educação Nacional, a educação de jovens e adultos é aquela destinada a pessoas "que não tiveram acesso ou continuidade de estudos no ensino fundamental e médio na idade própria”.

Dentre as conquistas e avanços neste tema, cita-se a aprovação, no início de 2009, pelo Conselho Nacional de Política Criminal e Penitenciária de uma proposta de Diretrizes Nacionais para Educação no Sistema Prisional, elaborada pelos participantes do Seminário Nacional pela Educação nas Prisões, realizado no ano de 2006 em Brasília.

Além disso, àquela época, apesar de não haver previsão de remição do tempo da pena por estudo em nossa legislação, editou-se em 2007 pelo Superior Tribunal de Justiça a súmula n. ${ }^{o}$ 341, que, apesar de não possuir força vinculante, representou um avanço importante para o reconhecimento do estudo como forma de reinserção social do condenado.

No entanto, este documento apenas replica parte do conteúdo das regras internacionais, sem qualquer adaptação à situação brasileira, como o faz, por exemplo, o capítulo XII da Resolução, ao dispor sobre as instruções e assistência educacional.

Por outro lado, o referido Relatório também noticia o problema da superlotação das unidades prisionais ao redor de todo o planeta, atingindo situações extremas na América Central e na África.

Segundo informações oficiais prestadas pela ONU, as taxas de encarceramento têm se elevado no mundo todo, levando a uma sensível piora nas condições dos estabelecimentos prisionais em geral.

Dentre os principais problemas constatados por esta missão da Relatoria, citam-se a grande participação de negros e pobres nas prisões, além do excessivo número de presos provisórios e muitos outros encarcerados de forma irregular (RELATORIA NACIONAL PARA O DIREITO HUMANO À EDUCAÇÃO, 2009).

Todos esses problemas se devem a uma dura política de encarceramento em massa, corroborado tanto pelo Judiciário e Legislativo quanto pela mídia.

Se de um lado as políticas penitenciárias se mostram repressoras e arbitrárias, de outro, pode-se também constatar alguns avanços da sociedade no sentido de buscar alternativas condizentes ao Estado Democrático de Direito. 
Nesse sentido, destacam-se alguns avanços, como a criação de ouvidorias dentro dos presídios; a criação de secretarias de administração penitenciária autônomas, e não mais atreladas às secretarias de segurança pública e de justiça; a criação do Programa Nacional de Direitos Humanos e do Plano Nacional de Segurança Pública, no governo de Fernando Henrique Cardoso.

Já no governo Lula, destaca-se a criação do Programa Nacional de Segurança com Cidadania em 2007, um ano após os registros dos ataques do crime organizado pelo PCC; anunciado pelo governo federal como um programa inovador, por unir políticas de segurança com ações sociais, priorizando a prevenção e a busca das causas da violência, sem se afastar das políticas de ordenamento social e segurança pública.

Com isso, uma das maiores prioridades deste Programa foi a reformulação do sistema carcerário. As principais ações para a busca dessa reestruturação envolvem: a construção de unidades prisionais voltadas aos jovens; a formação de agentes penitenciários; medidas específicas destinadas aos egressos, bem como reformas legais.

No entanto, é preciso que os juízes passem a adotar como padrão as medidas alternativas presentes nas recentes alterações trazidas pela Lei n. ${ }^{\circ} 12.403$, de 2011, ao Código de Processo Penal, cuja entrada em vigor se deu em 4 de julho de 2011, para tentar reverter o quadro da existência de milhares de pessoas que continuam nas prisões por crimes que poderiam ser punidos com medidas alternativas, significando menos custo para a sociedade, diminuição do índice de reincidência e maior chance de reinserção social do condenado.

Com relação às mulheres, também existe um grande déficit de vagas no sistema prisional, estimado em doze mil, ocasionando o problema da superlotação carcerária. No sistema carcerário em geral, a violação de direitos é ainda mais acentuada no caso das mulheres, reforçando a discriminação de gênero, ao negar-lhes o direito às visitas íntimas, o contato com os filhos e o acesso a uma educação profissionalizante para além daqueles pequenos cursos de oficina que possuem caráter essencialmente feminino.

No que diz respeito à situação dos profissionais do sistema penitenciário, existe uma grande resistência à aplicação de medidas que garantam a efetivação do direito humano à educação aos encarcerados, justificado, muitas vezes, por suas péssimas condições de trabalho e salários baixos.

A proposta de Emenda Constitucional n. ${ }^{\circ}$ 308, em tramitação no Congresso Nacional desde 2004, afirma a função de polícia penitenciária para estes agentes, mas, em 2009, o Conselho Nacional de Política Criminal e Penitenciária emitiu parecer contrário a 
esta PEC, afirmando que os textos contrariam o interesse público e sustentam as piores características do modelo repressor de polícia existente no Brasil. No entanto, a PEC conta com o apoio da própria categoria, tendo em vista a falta de perspectiva concreta de valorização desses profissionais.

Para a Relatoria, o grande desafio a ser enfrentado em caráter de urgência pelo governo federal é a criação de um projeto de lei para regulamentar a função de agente penitenciário, de acordo com as leis nacionais, como a Lei de Execuções Penais (LEP) e os documentos internacionais que tratam do assunto. Tal medida importaria na valorização do papel desses agentes para além da garantia da segurança nos territórios prisionais, reconhecendo a eles também a função educacional junto aos detentos (RELATORIA NACIONAL PARA O DIREITO HUMANO À EDUCAÇÃO, 2009).

Apesar de não haver dados precisos sobre a situação da educação nas prisões ao redor do mundo, existe uma estimativa de que menos de um terço da população encarcerada global tenha acesso a alguma atividade educativa no sistema prisional, apesar da existência de leis em diversos países que prevejam tais medidas. De maneira geral, o que se observa é a falta de políticas nacionais para esses fins, a falta de recursos financeiros e a ausência de atribuições de papéis e responsabilidades para os diversos setores ligados ao Estado.

Dentre os avanços, presentes principalmente nos países da América Latina, citamse as leis que garantem o direito à educação aos detentos, apesar de sua não aplicação na prática; a existência de leis que dispõem sobre a remição da pena por estudo e algumas tentativas visando à adoção de medidas para a efetivação desse direito.

No Brasil, de acordo com dados coletados pela Relatoria da Plataforma DhESCA (RELATORIA NACIONAL PARA O DIREITO HUMANO À EDUCAÇÃO 2009) e inseridos em seu respectivo Relatório, os números da educação dos detentos revelam a enorme precariedade do atendimento educacional brasileiro aos detentos, que enfrentam sérios problemas de acesso e de qualidade, a saber:

Dados do Ministério da Justiça apontavam que em 2004 cerca de $70 \%$ da população encarcerada no país não possuía o ensino fundamental completo e $8 \%$ são analfabetos. Do total de pessoas privadas de liberdade, mais de $60 \%$ era formada por jovens entre 18 e 30 anos e somente $18 \%$ tinham acesso a alguma atividade educativa.

Segundo informações do Ministério da Educação, o atendimento educacional se manteve em 2008 entre 18 a $20 \%$ da população carcerária, sendo que $45 \%$ dos analfabetos(as), $12 \%$ dos que possuem ensino fundamental incompletos e $6 \%$ 
dos que possuem ensino médio incompleto estavam matriculados na educação formal dentro das unidades prisionais.

Quando ofertada, a educação formal é de responsabilidade das secretarias estaduais de educação ou realizadas por meio de convênios com secretarias municipais, organizações não-governamentais ou com sistema S. Em São Paulo, a Secretaria Estadual de Educação não responde pela educação no sistema prisional, sendo essa assumida pela Funap - Fundação Prof. Dr. Manoel Pedro Pimentel de Amparo ao Preso, instituição vinculada ao governo do estado de São Paulo.

Além disso, não há uma unificação quanto ao financiamento da educação nas prisões, variando conforme o estado:

Para aqueles que a Educação das Prisões é vinculada à política de educação de jovens e adultos, há os recursos previstos no Fundeb (Fundo Nacional de Desenvolvimento da Educação Básica e Valorização dos Profissionais de Educação), mas nem todos estados nessa situação acessam tais recursos para garantir o atendimento. Há estados, nos quais o atendimento é garantido por meio de recursos do órgão do sistema prisional responsável pela educação. Em São Paulo, estado no qual a educação das prisões não foi assumido pela Secretaria Estadual de Educação, o atendimento é garantido pela Funap por meio de recursos gerados, em sua maior parte, da venda de produtos confeccionados por pessoas presas. A educação nas prisões também está prevista no programa Brasil Alfabetizado e no PAR - Plano de Ações Articuladas, vinculados ao Plano de Desenvolvimento da Educação (PDE), implementado pelo Ministério da Educação. (RELATORIA NACIONAL PARA O DIREITO HUMANO À EDUCAÇÃO, 2009, p. 27-28).

Apesar das diferenças numéricas, a situação das mulheres encarceradas e suas crianças que com elas permanecem é de extrema precariedade:

Das mulheres encarceradas, a maioria é jovem: 17,6\% têm entre 18 e 24 anos, $16,1 \%$ entre 25 e 29 anos, $12,5 \%$ entre 30 e 34 anos e $13,4 \%$ entre 35 a 45 anos, segundo dados do Infopen, divulgados em 2007. Do total de presas, 3,2\% são analfabetas; $9,8 \%$ têm o ensino fundamental completo; $6,3 \%$ o ensino médio e $0,5 \%$ o ensino superior. Da onde se deduz que quase $80 \%$ das mulheres não têm o ensino fundamental completo.

Segundo estudo realizado pela pesquisadora Rosângela Peixoto Santa Rita, divulgado em 2007, a situação das crianças que permanecem com suas mães encarceradas é extremamente precária. Cerca de $60 \%$ das unidades permitem somente que a criança permaneça com a mãe até os 6 meses de idade. No restante das unidades, há crianças até a idade de seis anos. Somente 18,9\% delas têm acesso a creches ou pré-escola, que oferecem em sua maioria um atendimento com problemas de qualidade. (RELATORIA NACIONAL PARA O DIREITO HUMANO À EDUCAÇÃO, 2009, p. 28).

Os dados acima apresentados revelam, para além dos problemas vividos pela população carcerária, a reafirmação das questões das desigualdades de gênero no ambiente prisional. 


\subsubsection{Aspectos específicos sobre o trabalho de campo da missão realizada em estabelecimentos prisionais desde outubro de 2008 até abril de 2009}

Conforme mencionado anteriormente, além das visitas aos onze estabelecimentos prisionais nos Estados de Pernambuco, São Paulo, Rio Grande do Sul, Pará e Distrito Federal, também foram realizadas neste período diversas reuniões, entrevistas, estudos, eventos e audiências públicas.

Em 28 de outubro de 2009, deu-se início aos trabalhos da missão em Pernambuco, com base numa reunião realizada pela equipe da Relatoria com as entidades de educação e direitos humanos de Recife, na sede da organização não governamental denominada Gabinete de Assessoria Jurídica às Organizações Populares (Gajop) (RELATORIA NACIONAL PARA O DIREITO HUMANO À EDUCAÇÃO, 2009).

Os diversos representantes de direitos humanos ali reunidos chamaram a atenção para o fato de que os ativistas que atuam no sistema prisional são tratados de forma desrespeitosa, inclusive aqueles que compõem o Conselho da Comunidade previsto na Lei de Execução Penal (LEP).

Ocorre que muitos diretores de unidades prisionais desconhecem a portaria que instituiu o Conselho da Comunidade, que prevê visitas e fiscalização a essas unidades, impedindo a entrada dos ativistas, principalmente quando ocorrem as rebeliões.

Além disso, constatou-se também a fragilidade política do Conselho Estadual de Direitos Humanos para coibir as diversas violações de direitos dos detentos, inclusive a existência de tortura nos estabelecimentos prisionais.

De um modo geral, as entidades demonstraram que a educação das pessoas encarceradas carece de uma proposta pedagógica adequada, pois quando ofertada nas unidades, a educação é concebida num caráter assistencialista, e não como um direito inerente a todos os cidadãos. 


\title{
4.4.3 A missão da Relatoria nas unidades prisionais de Pernambuco
}

Os dados coletados pela Relatoria acerca da situação prisional de Pernambuco revelam igualmente a situação de precariedade e déficit de vagas devido a um crescimento rápido da quantidade de detentos, corroborando as péssimas condições prisionais do País como um todo.

\begin{abstract}
Dados do Sistema Integrado de Informações Penitenciárias (Infopen), divulgados em junho de 2008, apontam que Pernambuco possui 86 estabelecimentos penitenciários cadastrados, sua população carcerária é de 18.888 pessoas, sendo 17.922 homens e 966 mulheres. Segundo o Infopen, a população encarcerada é composta por 3.828 brancos, 2.722 pretos, 12.124 pardos, 55 amarelos, 34 indígenas e 325 outros. Informações do governo estadual apontam a existência de somente 700 agentes prisionais para atuar no conjunto destas unidades.

Segundo informações do Plano Estadual de Segurança Pública de Pernambuco (2007), o sistema prisional pernambucano apresentou nos últimos anos crescimento acelerado do encarceramento, passando de 99 presos por $100 \mathrm{mil}$ habitantes em 1999, para 188 por 100 mil em 2007. O aumento foi de quase $90 \%$ em relação ao crescimento da população do estado. Este crescimento impactou a capacidade de confinamento nas unidades prisionais: o déficit de vagas era estimado em 7.467 vagas (2006).

A população carcerária de Pernambuco é eminentemente masculina, negra, jovem e de baixa escolaridade, apresenta $9 \%$ de índice de reincidência. Quarenta e seis por cento têm idade entre 22 e 30 anos, $23 \%$ entre 31 e 40 anos, $15 \%$ entre 18 e 21 anos e $15 \%$ mais de 40 anos. Aproximadamente $95 \%$ possuem baixo nível econômico. Sobre a escolaridade, $21 \%$ são analfabetos, $42 \%$ possuem o ensino fundamental incompleto e $15 \%$ ensino médio incompleto. (RELATORIA NACIONAL PARA O DIREITO HUMANO À EDUCAÇÃO, 2009, p. 32).
\end{abstract}

Além disso, o relatório traz a informação de que as Secretarias estimam que o atendimento educacional em Pernambuco alcance apenas $18 \%$ da população carcerária. (RELATORIA NACIONAL PARA O DIREITO HUMANO À EDUCAÇÃO, 2009).

Uma das unidades prisionais visitada pela Relatoria foi o presídio Aníbal Bruno, considerado um dos piores presídios do Brasil em 2008 pela Comissão Parlamentar de Inquérito do Sistema Penitenciário do Congresso Nacional. Esta é uma unidade transitória, destinada aos presos que aguardam sentença, caracterizada pela sua superlotação ${ }^{65}$, motivo que provocou duas rebeliões entre novembro de 2007 e janeiro de 2008.

O saldo da primeira rebelião fora a destruição da escola, cujas salas tiveram de ser reconstruídas por meio do trabalho dos próprios detentos. Apesar de o atendimento ter sido

65 "A unidade conta com uma população de 3.600 encarcerados, sendo sua capacidade para 1.448 pessoas" (RELATORIA NACIONAL PARA O DIREITO HUMANO À EDUCAÇÃO, 2009, p. 35). 
retomado em fevereiro de 2008, em quatro salas de aula, divididas em 20 alunos para cada sala e em dois períodos (manhã e tarde), a evasão e a transferência para outras unidades revela índices altos, além da dificuldade de atender à grande demanda dos alunos por aulas noturnas, devido a problemas de segurança.

Ao se entrevistarem os profissionais da educação daquele presídio, os relatos foram unânimes no sentido de que a grave situação de superlotação influencia diretamente no rendimento dos alunos em sala de aula, pois muitos usam drogas para suprir a questão da falta de espaço, preferindo manter-se acordados a dormir, devido à falta de espaço no chão para se deitarem ou por temerem a violência.

Em entrevistas feitas pela Relatoria aos detentos, muitos deles demonstraram interesse por ensino profissionalizante e acesso ao superior, até como forma de serem reconhecidos como "gente". No entanto, dificuldades de muitas ordens os impedem muitas vezes de continuarem frequentando a escola, o que os leva ao abandono dos estudos, conforme descrito na seguinte passagem do relatório:

\footnotetext{
A Relatora conseguiu conversar com alguns alunos e professores sem a presença das autoridades e dos chaveiros. Foi destacada na conversa as dificuldades cotidianas impostas por vários agentes ao acesso à escola, entre elas, a recusa ou demora na abertura das trancas, xingamentos contra alunos, a imposição de castigo aos presos que questionam tal comportamento, chantagens diversas e destruição de cadernos e livros. Foi apontado que vários alunos desistem da escola em decorrência dessas dificuldades. (RELATORIA NACIONAL PARA O DIREITO HUMANO À EDUCAÇÃO, 2009, p. 38).
}

Já a Penitenciária Barreto Campelo é considerada unidade para sentenciados de alta rotatividade, já que muitos deles pedem transferência para o regime semi-aberto, por se encontrarem em processo de progressão de pena.

Nesta unidade, a escola contava com onze professoras para realizar o atendimento de cerca de duzentos alunos, sendo que o relato das professoras sinalizou a falta de motivação dos presos em continuarem os estudos, devido à proximidade da mudança de regime.

Apesar de não faltarem vagas e não haver alta rotatividade de profissionais, um dos problemas enfrentados pelas professoras é o acesso à penitenciária, pois se localiza em região distante do centro, cuja oferta de transporte público é limitada.

Outra dificuldade relatada pelas professoras refere-se à incompatibilidade de horários na unidade prisional entre escola, trabalho, alimentação e procedimentos de segurança. Muitos alunos demonstram grande ansiedade ao final de aula do período 
matutino, pois como o horário do almoço inicia-se antes do término da aula, os detentos temem não restar comida para se alimentarem após a aula.

Outra visita realizada pela missão foi à Colônia Penal Feminina, presídio com a maior superlotação do estado de Pernambuco, caracterizada por ser a pior unidade prisional da área metropolitana. Esta unidade apresenta quatro encarceradas por vaga, num total de 670, sendo o limite fixado em 150, sendo elas provisórias, sentenciadas e provenientes de regime semiaberto que disputam a falta de espaço em situações de extrema precariedade.

De acordo com informações prestadas pela coordenadoria pedagógica da escola, das 150 alunas matriculadas, 97 frequentavam a escola. As aulas eram oferecidas nos três turnos (manhã, tarde e noite).

Um dos destaques realizados pela direção da unidade é a realização de ações de sensibilização junto às agentes penitenciárias para a valorização da educação, principalmente para aquelas que trabalham no período noturno, cuja resistência é maior devido à fragilidade da segurança da unidade.

Quanto ao material escolar, tanto os livros didáticos quanto o kit escolar são oferecidos com atraso. A unidade conta com uma biblioteca, sendo que há contradição entre o depoimento da diretora e das encarceradas quanto ao extravio das obras: segundo a diretora, não há qualquer penalidade nesse caso, mas, de acordo com o que fora relatado pelas presas, este fato acarreta a elas a aplicação de castigos por parte dos agentes, qual seja, a utilização de cela solitária.

Em meio a tantos contrastes, destaca-se na audiência pública realizada pelo Ministério Público de Pernambuco o fato de que a remição da pena por estudo é aplicada neste estado desde 2003, por intermédio de uma portaria, além do fato de que, desde 2002, permite-se o voto do preso em sessões eleitorais dentro do presídio (RELATORIA NACIONAL PARA O DIREITO HUMANO À EDUCAÇÃO, 2009).

Outra questão essencial e bastante aventada pelos participantes desta audiência pública fora a necessidade de se rever a aplicação das penas impostas à maior parte das pessoas que se encontram encarceradas naquele estado, pois estima-se que cerca de $40 \%$ delas poderiam se beneficiar pela concessão de penas alternativas.

Na mesma oportunidade, também foi relatado um grande óbice à efetivação da educação no sistema prisional, atinente às dificuldades de ações integradas entre os municípios. Além disso, foi deflagrado um ponto de tensão dentro do próprio sistema Judiciário, na medida em que há pouco diálogo entre os juízes e os promotores de justiça. 
Destaca-se, em meio à presente missão, importante reunião realizada entre a Relatoria e o senador de Pernambuco Jarbas Vasconcelos, autor do projeto de lei n. ${ }^{\circ}$ 230/2008, referente à questão da remição da pena por estudo em tramitação no Senado Federal. Com isso, pretendeu-se uma abertura no Senado de um debate público sobre este tema, acelerando-se a tramitação de projetos como este no Congresso.

\subsubsection{A missão da Relatoria nas unidades prisionais de São Paulo}

Igualmente precária revela-se a situação do sistema prisional de São Paulo, sendo que os dados da Funap, fundação estadual de direito público ligada à Secretaria de Administração Penitenciária, responsável pela administração das unidades prisionais do Estado, revelam que

[...] o estado de São Paulo conta com 147 unidades prisionais e 158.447 encarcerados, que representam $38 \%$ da população carcerária do país. Desta população, $96 \%$ são homens (sendo que 73\% estão na faixa de 18-34 anos de idade), e $4 \%$ de mulheres (65\% na faixa de 18-34 anos). A grande maioria dos encarcerados/as possui ensino fundamental incompleto. A média de reincidência de presos em São Paulo é de 58\%. O atendimento educacional no estado atinge cerca de $8,29 \%$ da população encarcerada. (RELATORIA NACIONAL PARA O DIREITO HUMANO À EDUCAÇÃO, 2009, p. 51).

Dentre as inúmeras dificuldades enfrentadas, citam-se aquelas vivenciadas pelos Conselhos de Comunidades existentes na lei de execução penal, como, por exemplo, a ausência de retorno às reivindicações encaminhadas às autoridades em geral, o engessamento nas decisões sobre local e horário das visitas de monitoramento às unidades prisionais, ausência de autonomia na decisão do sentenciado em ser entrevistado, bem como a dificuldade de acesso e diálogo com as direções dos estabelecimentos prisionais.

Nas reuniões realizadas com a sociedade civil, também ressaltou-se a necessidade de que a educação prisional deste estado esteja vinculada à Secretaria Estadual de Educação, por integrar a política de educação de jovens e adultos, bem como a necessidade de criação de uma política voltada para egressos e a erradicação das diferenças no atendimento entre homens e mulheres dentro deste sistema.

Um dos estabelecimentos prisionais visitados foi o Centro de Detenção Provisória de Diadema, que recolhia 956 presos, dentro de uma capacidade máxima de 576 detentos. 
Dentre eles, havia 217 presos que já estavam sentenciados, porém, ali permaneciam no aguardo de sua transferência para uma penitenciária.

Com relação à educação, constatou-se que apenas 40 presos participavam da oferta educacional, sendo que a maior parte dos alunos está em nível de escolaridade fundamental, e aproximadamente $10 \%$ deles são analfabetos.

Foram destacados inúmeros problemas de ordem educacional pela direção do estabelecimento, mas a falta de vagas e a necessidade de educadores mais experientes foram apontados como os principais, além da existência de tensas relações entre os agentes penitenciários e os alunos.

A maioria dos alunos possui um perfil escolar marcado por inúmeras repetências e evasões, sendo comum o quadro depressivo da maior parte deles.

Já os dados coletados em dezembro de 2008 a respeito da Penitenciária feminina de Sant'Anna dão conta de que ali haviam 2.539 mulheres encarceradas, sendo 1.816 condenadas e 723 provisórias, dentro de uma capacidade total de 2.400 vagas. Neste local, a média de idade varia entre 25 e 26 anos, sendo que a maior parte dos crimes por elas praticados refere-se ao envolvimento no tráfico de entorpecentes, principalmente na função de "transportadoras" de drogas. (RELATORIA NACIONAL PARA O DIREITO HUMANO À EDUCAÇÃO, 2009).

Um grande dilema constatado nesta unidade é que não é possível conciliar estudo com trabalho, devido à incompatibilidade de horários. Com isso, a educação fica em situação de desvantagem, pois a maioria delas acaba por optar pelo trabalho em decorrência da renda, além da maior parte dos empresários não procurar alternativas de horários para que haja possibilidade das presas estudarem.

Existe também uma alta rotatividade das alunas encarceradas nas aulas, devido a transferências para outras unidades ou mudança para o regime semiaberto, dificultando a aplicação do conteúdo escolar previsto.

Além disso, falta material didático e acompanhamento pedagógico adequado, além da função de monitora ser ocupada pelas próprias encarceradas, e não por profissionais de educação com formação adequada para tal.

Outra visita realizada pela Relatoria foi à unidade de segurança máxima masculina de Tremembé, onde se encontravam criminosos de alta periculosidade, incluindo os líderes da facção criminosa denominada Primeiro Comando da Capital (PCC). 
Neste local, constatou-se superlotação, além da falta de funcionários; no entanto, a direção tem procurado manter a escola, apesar da resistência dos próprios agentes penitenciários ao atendimento à educação.

Apesar de a oferta de educação ser maior que a demanda, esta penitenciária tem espaço para atividades escolares, biblioteca, sala de artes e música. Porém, existe uma incompatibilidade entre os horários de estudo e trabalho, contribuindo para a evasão escolar, pois a maioria opta pelo trabalho.

Em visita à Fundação Prof. Dr. Manoel Pedro Pimentel de Amparo ao Preso (Funap), o maior problema apontado por seus dirigentes na educação prisional é a falta de interesse do preso, que, naquela época, poderia ser maior se houvesse a lei que garantisse a remição da pena por estudo.

Foram apontados por esses dirigentes que a proposta pedagógica de monitores presos ou educação entre pares surgiu devido à falta de funcionários e de orçamento, sendo relatadas também tensões entre a direção da Funap e a Secretaria Estadual de Educação.

Além disso, existem alguns relatos de que os próprios diretores de presídios dificultam a realização de atividades escolares nas unidades prisionais.

Em entrevista da Relatoria com o Prof. Roberto da Silva, doutor em Educação pela Universidade de São Paulo, este defende a ideia de que a educação nas unidades prisionais seja assumida pelas secretarias de educação como parte das políticas educacionais, de modo que a educação prisional esteja atrelada às demais áreas sociais, além da existência de projetos pedagógicos na prisão.

No que diz respeito à remissão da pena por estudo, defende a ideia de estar ligada à conclusão de etapas educacionais, diferenciando-se do modelo existente em relação à remição por trabalho.

Outro ponto destacado por ele refere-se à importância das informações sobre a trajetória escolar dentro das unidades prisionais, como, por exemplo, a situação da escolaridade do preso em sua entrada e posterior saída do presídio.

Em entrevista com a representante da Secretaria Estadual de Educação, Profa. Huguette Theodoro da Silva, esta defendeu a ideia de que a educação no sistema prisional é capaz de modificar o comportamento dos internos, porém o acesso a uma vaga de trabalho na prisão somente deveria ser garantido àqueles que estivessem estudando. Além disso, considerou que a tarefa de professor não deve ser atribuída ao monitor-preso, pois existem regras estabelecidas para esta função. 
Por outro lado, as diversas solicitações de entrevistas pela Relatoria aos representantes da Secretaria de Administração Penitenciária de São Paulo não foram atendidas.

\subsubsection{A missão da Relatoria nas unidades prisionais do Rio Grande do Sul}

Os dados buscados pela Relatoria sobre a situação da população carcerária neste estado revelam que:

[...] a população carcerária em outubro de 2008 era de 27.202 pessoas para 17 mil vagas. Do total da população, $95,11 \%$ eram homens e 4,89\% mulheres. Destes, 26,24\% estavam na faixa de 25-29 anos e 24,78\% na faixa de 18-24 anos. Por pertencimento racial, brancos representavam $67,34 \%$, negros $12,33 \%$ e outros $19,86 \%$.

Por grau de instrução, 4,64\% dos presos eram analfabetos, 7,48\% alfabetizados, $63,29 \%$ ensino fundamental incompleto, $11,91 \%$ possuíam o ensino fundamental completo, 4,27\% ensino médio, 7,09\% ensino médio incompleto, $0,34 \%$ ensino superior, $0,76 \%$ ensino superior incompleto, e $0,22 \%$ não informaram. $\mathrm{O}$ estado conta com 91 unidades prisionais, sendo que 29 possuem atendimento educacional. A educação nas prisões do estado mobiliza 156 professores e apresenta 1.539 alunos matriculados, sendo 736 na alfabetização, 534 no ensino fundamental, 266 no ensino médio e 3 no ensino superior.

$[\ldots]$

A meta 15 do Plano Diretor do Sistema Penitenciário-educação e profissionalização do Rio Grande do Sul informa que dos 91 estabelecimentos penais, 46 possuem algum tipo de atividade educativa destinado à educação e profissionalização dos presos. Destes, somente 11 possuem salas de aula apropriadas e 35 passaram por algum tipo de adaptação de espaços para viabilizar as atividades educativas. (RELATORIA NACIONAL PARA O DIREITO HUMANO À EDUCAÇÃO, 2009, p. 64).

Em resumo, os problemas mais frequentes enfrentados pelo sistema prisional deste estado dizem respeito à superlotação das unidades. Dentre elas, recebe destaque negativo o Presídio Central de Porto Alegre, que está entre as dez piores unidades do Brasil.

Em visita da Relatoria à Penitenciária Feminina Madre Pelletier, tem-se que a situação escolar é semelhante às demais unidades visitadas nos outros Estados, em que muitas detentas abandonam os estudos devido à mudança de regime de pena, bem como por problemas de saúde mental.

Outros pontos comuns em relação aos demais estabelecimentos prisionais referemse aos obstáculos trazidos pelos agentes prisionais no que diz respeito à liberação das presas para as aulas, a dificuldade em conciliar os horários das demais atividades diárias e 
das aulas e a comunicação falha entre a direção do estabelecimento prisional e a direção da escola.

No entanto, a Relatoria teve a oportunidade de relatar estes e outros problemas enfrentados pelas unidades prisionais no Seminário Educação no Sistema Prisional, realizado nos dias 27 e 28 de novembro de 2009, na Universidade Federal do Rio Grande do Sul.

\title{
4.4.6 A missão da Relatoria nas unidades prisionais do Pará
}

De acordo com o presente Relatório, o Estado do Pará possui a seguinte situação carcerária:

\begin{abstract}
Segundo dados de junho de 2008 do InfoPen, o estado do Pará conta com 37 estabelecimentos penais. São 6.097 vagas para uma população carcerária de 7.825 pessoas, sendo 7.488 homens e 337 mulheres. Além destas pessoas, existem outras 1.868 pessoas presas em cadeias e unidades provisórias.

A população encarcerada é composta por 3.843 são brancos, 2.300 pardos, 1.682 pretos. A maioria tem entre 18 e 29 anos de idade. Por grau de instrução, 270 são analfabetos; 469 alfabetizados; 922 possuem o ensino fundamental incompleto; 1.260 apresentam o fundamental completo; 1.693 o ensino médio incompleto; 3.174 o ensino médio completo e 37 têm o ensino superior incompleto. (RELATORIA NACIONAL PARA O DIREITO HUMANO À EDUCAÇÃO, 2009, p. 71).
\end{abstract}

Das 37 unidades do estado, somente 13 contam com atendimento educacional são 5 no Polo Americano, 7 no Polo Metropolitana, e uma em Castanhal, no interior do Estado. O governo estadual planeja concluir em 2009 o mapeamento das condições de todas as unidades visando à expansão do atendimento educacional. O sistema conta com 780 alunos matriculados nas escolas pelo projeto Educando, mas não há dados sobre os alunos atendidos por convênios diretos firmados pela Susipe com as prefeituras do interior do estado.

$\mathrm{O}$ número de alunos por turmas e quais das pessoas da lista de espera terão acesso a uma vaga na escola são definidos pelo setor de segurança de cada unidade.

Segundo as entrevistas, o setor faz a seleção a partir de critérios de "bom comportamento" e de duração da pena. Geralmente as turmas contam, no máximo, com 15 alunos(as) por turma.

As professoras e professores que atuam no sistema prisional paraense estão vinculados à Secretaria Estadual de Educação por meio de contratos temporários. Há um coordenador pedagógico que supervisiona o trabalho nas unidades. Todas as salas de aula são espaços adaptados. (RELATORIA NACIONAL PARA O DIREITO HUMANO À EDUCAÇÃO, 2009, p. 72).

Assim como ocorre nos outros estados, um dos maiores problemas enfrentados no atendimento educacional refere-se à grande resistência por parte dos agentes penitenciários 
à educação. Com base nisso, iniciou-se no Pará um processo de sensibilização a esses indivíduos visando à valorização da educação.

No sistema educativo do estado do Pará, destaca-se o desenvolvimento de atividades de educação física e de arte-educação em algumas unidades, diferentemente dos outros estados, em que os detentos não realizam nenhum tipo de atividade desta natureza.

No entanto, nos quesitos relativos à impossibilidade de se conciliar horário de estudo com o de trabalho, e à falta de material didático, as unidades prisionais do Pará se equiparam aos demais estados, em prejuízo à educação.

Mesmo diante dos diversos problemas existentes, dois detentos entrevistados pela Relatoria apontaram avanços significativos na educação na prisão, como, por exemplo, a existência de mais de uma professora na tarefa de alfabetização, assim como o atendimento até o ensino médio.

Destaca-se a participação da Relatoria Nacional para o Direito Humano à Educação no Fórum Social Mundial, realizado entre os dias 27 de janeiro e 1 de fevereiro de 2009 na cidade de Belém, para a realização de atividade relativa ao tema A educação como direito humano: a escola na prisão, objetivando a implementação de políticas educacionais nas prisões do Brasil.

Nesta oportunidade foram abordados assuntos fundamentais ligados à efetivação do direito humano à educação para as pessoas encarceradas, tais como: a omissão dos governos, as tensas relações entre educação e segurança, a incompatibilidade entre trabalho e estudo para os presos, e a participação da sociedade civil no processo de criação de oportunidades ligadas à educação, contando com a participação de mais de 150 pessoas (RELATORIA NACIONAL PARA O DIREITO HUMANO À EDUCAÇÃO, 2009).

\subsubsection{A missão da Relatoria na unidade prisional do Distrito Federal}

Naquele mesmo ano, a Relatoria lançou em Brasília o informe preliminar da missão no Congresso Nacional, juntamente com representantes da ONU e Unesco Brasil em educação.

De acordo com os dados coletados pela Relatoria sobre o sistema prisional de Brasília, 
Os dados do Infopen informam que o Distrito Federal possui seis estabelecimentos penais cadastrados, com uma população de 7.712 presos, sendo 7.292 homens e 420 mulheres, para um conjunto de 6.335 vagas. Os brancos são 2.012, pardos 4.753, 821 pretos, 27 amarelos e 28 estão na categoria Outros.

As atividades educacionais e de trabalho realizadas nos estabelecimentos penais do Distrito Federal são de responsabilidade da Fundação de Amparo ao Trabalhador Preso do Distrito Federal - Funap/DF, órgão vinculado à Secretaria de Estado de Justiça, Direitos Humanos e Cidadania do DF, através de convênios com a iniciativa pública e privada.

Setecentos e trinta (730) alunos e duzentas (200) alunas são atendidos por meio de convênio da Funap com a Secretaria de Educação do Distrito Federal, que garante os profissionais de educação para o sistema. Outros 488 participam de cursos profissionalizantes de informática. (RELATORIA NACIONAL PARA O DIREITO HUMANO À EDUCAÇÃO, 2009, p. 79).

Em visita ao Complexo Penitenciário da Papuda, formado por quatro estabelecimentos prisionais, constatou-se que a educação dispõe de 156 vagas e conta com apenas seis professores.

Com isso, existem os mesmos problemas relatados anteriormente, tais como a existência de 120 alunos em lista de espera, a falta de funcionários nas unidades, limitações de espaço físico, impossibilidade de conciliação entre estudo e trabalho e resistência por parte dos agentes penitenciários à frequência dos alunos, acarretando entraves à ampliação do atendimento escolar.

Ao final da leitura dos dados apresentados neste Relatório, encontram-se o parecer e as recomendações da Relatoria, relacionando o direito humano à educação nas prisões brasileiras ao contexto do sistema prisional, devido à indivisibilidade dos direitos humanos. Com base nisso, por exemplo, o direito humano à educação deve ser articulado conjuntamente ao direito humano à saúde, pois muitos dos problemas de saúde física e mental enfrentados pelos detentos comprometem o processo de aprendizagem dos mesmos.

Assim sendo, considera-se obrigação de nosso País combater de forma efetiva toda impunidade referente a crimes cometidos contra a sociedade e contra o Estado, porém, não prioritariamente por meio do encarceramento das pessoas, visto que tal modelo geralmente apenas evidencia os conflitos sociais decorrentes dos diversos tipos de desigualdades e da falta de acesso a direitos fundamentais (RELATORIA NACIONAL PARA O DIREITO HUMANO À EDUCAÇÃO, 2009).

De acordo com os elementos e dados extraídos pela missão da Relatoria, constatase que grande parte dos estabelecimentos prisionais enfrenta problemas graves e constantes de superlotação, onde estão presentes condições degradantes e desumanas aos que ali se encontram, palco de contínua violação aos direitos humanos em geral. 
Corroborando este cenário, o sistema Judiciário e seus operadores preferem optar por este tipo de punição a se valerem de penas alternativas, produzindo um número de prisões que está sempre em constante elevação, não suportado pela estrutura administrativa existente.

Com isso, a educação nas prisões ainda é vista como um privilégio pelo sistema prisional, e não como um direito inerente a todo ser humano, num contexto em que o próprio sistema carcerário é tido como castigo, e não como oportunidade para a ressocialização do indivíduo.

Por essas razões, tem-se que o atendimento educacional é descontínuo, pois a educação é negociada em troca da manutenção da ordem disciplinar. Isso resulta também em sérios problemas de qualidade, já que ocorrem contínuas interrupções no atendimento. Além disso, não há infraestrutura e materiais adequados para garantir a regularidade do aprendizado dos educandos. 


\section{CONSIDERAÇÕES FINAIS}

O presente tópico possui a proposta de retomar as discussões iniciais apresentadas nesta dissertação de mestrado, buscando alcançar o objetivo da pesquisa desenvolvida ao longo deste trabalho. Para tanto, este tópico se utilizará tanto da análise dos dados coletados nas missões da Relatoria quanto de outros elementos para a reflexão em torno deste tema. Com isso, renova-se a busca à proximidade do objeto de pesquisa perseguido durante esta investigação, distanciando-se, porém, da pretensão de esgotamento do presente assunto.

Confrontando-se os dados trazidos pelos relatórios e pelas respectivas recomendações, redigidos a partir de consultas públicas organizadas em todo o território nacional, poder-se-á notar que houve avanços e até uma rapidez nas mudanças, ainda que nem todos tenham ocorrido de forma estrutural. Em geral, nota-se que há um movimento novo no país, permitindo um maior diálogo entre o governo e a sociedade civil, resultando em tensas relações, porém bastante frutíferas.

Por exemplo, em 2003, época da missão da Relatoria no Ceará, havia pouco tempo que o Fundo de Manutenção e Desenvolvimento do Ensino Fundamental e de Valorização do Magistério (Fundef) havia sido criado; um dos maiores problemas nele constatados fora, exatamente, a exclusão do financiamento da educação de jovens e adultos da educação fundamental o que foi posteriormente sanado (pelo menos formalmente) por meio do Fundo de Manutenção e Desenvolvimento da Educação Básica e Valorização dos Profissionais da Educação Básica (Fundeb). Foi no primeiro mandato do governo Lula que o Fundef foi substituído pelo Fundeb, por meio da Emenda Constitucional n. ${ }^{\circ}$ 53, de 19 de dezembro de 2006, que incluiu o financiamento do ensino médio e outras demandas da sociedade civil.

Outro importante elemento a ser destacado é a presença maior de mulheres no ensino médio, resultante do fato de a mulher estar sendo mais preservada que o homem de uma entrada precoce no mercado de trabalho.

Na parte destinada à exposição das informações gerais sobre o ensino brasileiro, o próprio conteúdo do relatório de 2003 dá conta das tentativas de redução da desigualdade educacional por parte dos governos, pois constatou-se que, entre o início dos anos de 1990 até os primórdios da década seguinte, o ensino fundamental teve praticamente a 
universalização de seu atendimento e um grande crescimento em relação ao atendimento do ensino médio.

Além disso, houve um aumento maior em relação ao número de matrículas totais onde há maior pobreza no Brasil, comparando-se às regiões mais ricas, relativo ao incremento da democratização da oferta no mesmo período acima mencionado. O ensino básico, por sua vez, também apresentou um notável crescimento por conta da ampliação do ensino público.

Quanto aos programas governamentais, relembra-se a criação de ouvidorias dentro dos presídios, das secretarias de administração penitenciária autônomas, bem como do Programa Nacional de Direitos Humanos e do Plano Nacional de Segurança Pública no governo de Fernando Henrique Cardoso.

O Plano Nacional de Segurança Pública constitui-se em um plano de ações, representado por um conjunto de propostas integradas entre políticas de segurança, políticas sociais e ações comunitárias, com o intuito de reprimir e prevenir o crime e reduzir a impunidade, de forma a promover um aumento na segurança e tranquilidade do cidadão brasileiro. (BRASIL, 2000).

Recentemente, cita-se a implantação do Programa de Aceleração do Crescimento, que, nas regiões das favelas, passou a ser denominado "PAC das favelas", aliado ao Programa Nacional de Segurança Pública com Cidadania (Pronasci) criado em 2007, no governo Lula. Dentre as comunidades, uma das primeiras a ser considerada foi a do Complexo do Alemão, cujo objetivo do projeto constitui a construção de escolas e demais obras de infraestrutura básica para seus moradores.

Em relação ao sistema carcerário, tal projeto envolvia a construção de unidades prisionais voltadas aos jovens, a formação de agentes penitenciários, a previsão de medidas especialmente desenvolvidas e voltadas aos egressos e outros.

Dentre os resultados positivos obtidos pelas missões da Relatoria do Direito Humano à Educação, cita-se o Relatório de 2009 sobre educação nas prisões brasileiras, pois tal documento se transformou num importante instrumento para a elaboração e consequente aprovação das diretrizes nacionais de educação nas prisões pelo Conselho Nacional de Educação.

Esse trabalho desenvolvido pela Relatoria, além da atuação de algumas organizações da sociedade civil favoráveis à disseminação da educação para os detentos resultou em outro importante avanço para o País, representado pela alteração da lei de execução penal sobre a remição de pena. 
Esta última constitui um exemplo bem-sucedido de pressão política representada por estes relatórios para a implementação de políticas públicas prisionais, que culminou na entrada em vigor da Lei n. ${ }^{\circ}$ 12.433, de 30 de junho de 2011, que alterou o artigo 126 da Lei de Execução Penal para incluir a normatização da remição da pena por estudo.

De acordo com a recente lei que permitiu a alteração na LEP, para cada doze horas de estudo no ensino fundamental, médio, superior ou curso profissionalizante, o reeducando pode reduzir a pena em um dia, desde que as doze horas sejam distribuídas em pelo menos três dias de estudo (INFANTI, 2011).

Tal medida significou enorme avanço em nossa legislação, uma vez que, na lei anterior, somente era possível que o preso remisse pena por meio de trabalho. Assim, fica realçada a importância dos relatórios das missões e da forte atuação das organizações não governamentais, pois, além de produzirem com periodicidade informações sobre a situação dos direitos humanos no Brasil, esses documentos acabam servindo como instrumento apto para que o governo brasileiro faça frente ao Comitê de Direitos Econômicos, Sociais e Culturais das Nações Unidas para a implementação do Pacto Internacional de Direitos Econômicos, Sociais e Culturais (Pidesc) nas políticas públicas brasileiras, mediante a efetivação de projetos legislativos referentes à proteção dos direitos humanos em geral.

No entanto, conforme constatado ao longo da pesquisa, para que a educação se torne efetiva, esta deve ser entendida como um direito humano. Porém, sua plena efetivação também está condicionada à realização de outros direitos, devido à indivisibilidade e interdependência inerente aos direitos humanos.

Nos dizeres de Katarina Tomasevski (2004, p. 13), ex-relatora especial da ONU para o direito à educação, este direito opera como um multiplicador. Assim, quando ele é garantido e respeitado, há uma melhoria de todos os outros direitos humanos. Porém, quando este direito é negado ocorre a anulação, senão de todos, certamente da maioria dos direitos ${ }^{66}$.

Como bem ressaltado pela referida autora, para que a educação seja reconhecida efetivamente como um direito humano, deve-se desconstituir o consenso global formado

66 Trecho extraído do original em espanhol: "El derecho a la educación opera como multiplicador. Cuando se garantiza, mejora todos los otros derechos humanos; cuando se niega, anula el disfrute de la mayoría, si no de todos". (TOMASEVSKI, 2004, p. 13, tradução livre). 
em torno da educação que a inseriu num contexto mercadológico, onde se operam os abusos de poder, o que a fez se distanciar de sua função pública e essencial inicial ${ }^{67}$.

A realização da educação como um direito humano representaria um grande marco para as gerações futuras, pois, dessa forma, cairiam por terra os discursos populistas e eleitoreiros (PATTO, 2007) que sempre nos sugeriram uma visão limitada da educação, reduzindo o seu papel social fundamental de formar cidadãos para o exercício de seus direitos.

Além disso, a valorização da educação enquanto direito humano permite a formação de cidadãos capazes de tomarem atitudes críticas perante seus diversos papéis exercidos dentro da sociedade, sendo que o exercício efetivo desse direito contribui para o alcance de evoluções significativas no processo de consolidação do Estado Democrático de Direito.

67 "El Banco Mundial comenzó a otorgar prestamos para educación en 1962, dieciocho años después de haberse creado. El motivo por el que se otorgaron entonces y no antes fue explicado por dos miembros del staff de educación del Banco de ese momento, George Psacharopulous y Maureen Woodhall:

'La educación, como otras formas de inversión en capital humano, puede contribuir al desarrollo económico y elevar el ingreso de los pobres de manera equiparable a las inversiones en infraestructura...

Sin embargo, cuando el Banco fue creado en 1944, la educación no se contaba entre las metas productivas por las que se autorizaba a facilitar créditos. Esta actitud prevaleció durante los años 50, cuando las declaraciones oficiales sobre las políticas del Banco consideraban que este debía concentrar sus prestamos en proyectos diseñados para hacer una contribución directa a la capacidad productiva de sus miembros... Una de las principales razones para el cambio de perspectiva fue el creciente interés por el valor económico de la educación, em los $60 \ldots$ En poco tiempo, los economistas estaban tratando de medir la contribución de la educación en el crecimiento económico y muchos evaluaban el concepto de inversión en capital humano... (Psacharoupoulos, G. y Woodhall, M., Education for Development. An Analysis of Investment Choices, Banco Mundial/Oxford University Press, 1985, pp. 3/4).

Como muestra esta cita, los primeros documentos del Banco Mundial se referían a la educación como un derecho humano. El término desapareció debido a que la educación fue transferida del sector público al privado con la siguiente explicación:

'Se usaron pocos critérios tradicionales para determinar si la esfera pública es adecuada para la educación. [...] Sin embargo, existen dos aspectos de la educación que llevan a algunos a creer que debería ser una actividad del sector público. En primer lugar, muchos de los beneficiários - los chicos y las chicas - son considerados demasiado jóvenes para tomar decisiones por sí mismos. En segundo lugar, se dice que el gobierno debería tomar la decisión por ellos y proveer el servicio porque los padres pueden no reconocer las necesidades educacionales de sus hijos e hijas o no contar con los medios para satisfacerlas. Este argumento es débil por dos razones. Primero, no se relaciona específicamente con la educación sino con todos los servicios que se proveen a personas incapaces de cuidarse por si mismas. Éstas incluyen no sólo a los muy jóvenes y los muy viejos, sino también a los incapacitados por enfermedades. (...) Segundo, no hay nada que indique que la provisión estatal sea la mejor solución para las famílias pobres que no pueden pagar la educación de sus hijos e hijas. Las necesidades de estas familias pueden satisfacerse a través de préstamos estudiantiles o becas... [...] Además, las escuelas privadas están mejor adaptadas para cambiar sus métodos según los nuevos requerimientos, en comparación con las instituciones estatales'. (Roth G., The Private Provisiono $f$ Public Services in Developing Countries, EDI Series in Economic Development, Banco Mundial/Oxford University Press, Washington D.C., 1987, pp. 29/21).

Esta lógica sacó la educación del sector público, transfiriéndola al sistema de libre mercado. El efecto a largo prazo fue la desaparición de la noción de educación como derecho, y de la correspondiente responsabilidad pública, de los documentos del Banco Mundial. Esto se aplicó por primera vez en Malaui con resultados desastrosos". (TOMASEVSKI, 2004, p. 104-104). 
Ocorre que os dados colhidos pela Relatoria do Direito Humano à Educação aqui apresentados, relativos à efetivação deste direito são desoladores: as tentativas de redução da desigualdade educacional representadas pelo crescimento do número de vagas não foram suficientes para suprir as necessidades dos educandos, revelando, ao contrário, outra fragilidade do sistema de ensino brasileiro, qual seja, a precariedade em relação à sua qualidade.

Assim sendo, a tentativa de erradicação dos problemas de acesso acabou por gerar uma nova forma de exclusão, relativa à falta de permanência dos alunos na escola, devido aos altos índices de evasão e repetência ocorridos diante da péssima qualidade do ensino ofertado, da infraestrutura disponibilizada e de outros fatores, como as desigualdades de raça e gênero presentes nos ambientes escolares.

Pela análise dos relatórios brasileiros sobre educação, constata-se de fato a indivisibilidade dos direitos humanos, visto que a educação não se opera, por exemplo, em áreas violentas, marcadas pelos constantes conflitos armados entre policiais e narcotraficantes, a exemplo das favelas no Rio de Janeiro. Em épocas de confrontos, as aulas são suspensas, restando como saldo desses embates o medo e a destruição dos espaços reservados à educação.

Já no ambiente prisional, a resistência à realização efetiva da educação é um problema vivenciado constantemente pelos detentos, advinda dos próprios agentes do Estado como forma de punição àqueles que não possuem bom comportamento. Além disso, o material escolar não sobrevive às inúmeras operações truculentas dos policiais durante as investigações, tanto nas favelas quanto nos presídios.

Além da questão da violência, quando não é garantido o direito à saúde (no caso dos detentos) e saneamento, ou quando não existem instalações físicas adequadas para constituir um ambiente escolar, vale dizer, que possua requisitos mínimos de infraestrutura (no caso da educação de crianças, jovens e adultos em geral), não é possível que a educação se efetive.

É o próprio Estado que se nega a assumir sua responsabilidade perante determinados grupos de indivíduos, a exemplo do que ocorre com os habitantes de favelas, como no Rio de Janeiro e com a população que vive no cárcere.

Do ponto de vista social, tem-se que o preconceito e as diferenças sociais corroboram para que esta exclusão em relação à educação se perpetue em nosso País. 
Do ponto de vista jurídico, tem-se que a igualdade preconizada em nossa Constituição Federal possui apenas caráter formal, e não material, devido ao fato de não se consolidar na prática.

Como vimos, a própria interpretação das normas pelo Judiciário brasileiro e seus operadores em geral é obscura, tornando a prestação educacional inviável no plano concreto.

O que se verifica na prática é a educação ainda longe de ser reconhecida como um direito humano: além dos dados empíricos colhidos nos relatórios, citou-se, como um dos exemplos, o Programa Nacional de Direitos Humanos, que traz uma visão da educação como simples instrumento para a conquista de outros direitos, e não como um direito em si.

Assim sendo, os óbices à realização efetiva deste direito são inúmeros, não constituindo exagero afirmar que algumas iniciativas governamentais, ainda que tenham sido firmadas com a finalidade da concretização desse direito, geram descrença por parte de seus próprios beneficiários, a exemplo dos conflitos entre os moradores e os agentes do Estado, gerados quando do início das obras do PAC nas favelas do Complexo do Alemão.

Isso se explica porque tais políticas vêm sempre desacompanhadas de participação e consulta popular, gerando a (fundada) desconfiança de seu público-alvo, já cansado e desacreditado pelo temor e falta de segurança que os circundam diariamente.

Por outro lado, a atuação conjunta dos membros da sociedade civil organizada, acrescida dos representantes dos três poderes e demais operadores do direito e da administração pública pode constituir uma possível solução para a questão da efetividade desse direito ${ }^{68}$.

68 Oscar Vilhena Vieira e Andrew Scott Dupree (2005, p. 142-144) refletem sobre a importância de uma sociedade civil forte para o respeito aos direitos humanos: [... "Em um mundo dominado pelo mercado e por Estados, o contínuo debate social, político e econômico que tem lugar na sociedade civil é essencial para a criação e o fortalecimento das condições necessárias para o respeito aos direitos humanos. Isso não diminui a importância estratégica de desenvolver um bom governo democrático e nele incorporar a responsabilidade social. No entanto, modelos de direitos humanos mais responsáveis somente serão catalisados por uma sociedade civil saudável. [...] As organizações e associações da sociedade civil assumem diferentes formas, mas têm em comum a característica de ampliar as vozes dos interesses particulares e advogar naturalmente em favor dos grupos excluídos e invisíveis. Jean Cohen e Andrew Arato apontam quatro características da sociedade civil que tomamos como estrutura para entender a amplitude do impacto potencial que a discussão dos direitos humanos causa na sociedade civil: publicidade (instituições de cultura e comunicação); pluralidade (diferenciação de interesses e formas); privacidade (um ambiente que sustente o desenvolvimento e a expressão do indivíduo); e legalidade (a estrutura de leis e direitos básicos que propiciem a publicidade, a pluralidade e a privacidade). [...] A efetivação dos direitos é um processo, que não se dá unicamente pela incorporação de direitos em estruturas legais nacionais e internacionais. A sociedade civil cria e recria as condições para validar e concretizar os direitos humanos. Enfatizamos cinco aspectos dessa ação: (1) oferecer uma esfera de discussão para todos os grupos sociais; (2) tornar pública a injustiça; (3) proteger o espaço privado da 
Um exemplo concreto e viável seria reunir forças entre estes cidadãos no sentido de proporcionar maior diálogo entre todos os setores ${ }^{69}$, principalmente para a criação de políticas públicas integradas, tomando-se como ponto de partida a indivisibilidade e interdependência dos direitos humanos, a abertura à consulta e participação popular nessas iniciativas e a transparência do investimento dos recursos na área educacional.

E para que estas políticas públicas sejam efetivas e atendam aos anseios da sociedade em geral, faz-se necessária a utilização de instrumentos fidedignos, que ilustrem a realidade como de fato se apresenta, a exemplo dos relatórios produzidos pela Plataforma DhESCA.

Como visto, estes relatórios retratam fielmente a reprodução destes direitos no plano concreto, pois são produzidos mediante pesquisa séria e complexa, que inclui o trabalho de campo das missões, onde se realizam consultas e entrevistas a todos os cidadãos envolvidos na contraprestação do direito: desde as autoridades públicas, responsáveis pela organização e implementação das políticas, passando por todos aqueles que executam o direito, a exemplo dos professores, educadores e demais profissionais ligados à educação até atingir diretamente os seus beneficiários. Após coletados e reunidos, todos os dados levantados são analisados, para que apenas depois passem a ser feitas as devidas constatações e recomendações.

Por esses motivos, faz-se necessária a divulgação e reconhecimento desses relatórios como instrumento oficial e legítimo no apoio à criação das políticas públicas, pois reúnem todos os principais requisitos que visam à efetividade desses direitos. Reconhecidos desta forma pelas autoridades governamentais, esses documentos estariam aptos a produzir efeitos imediatos no que diz respeito às recomendações neles contidas.

incursão do Estado e do mercado; (4) intervir e interagir diretamente nos sistemas legais e políticos; (5) promover a inovação social."

69 Sobre este aspecto, Vieira e Dupree (2005, p. 153) ponderam que: [...] “A discussão dos direitos humanos não é um mecanismo para a resolução dessas questões; é um espaço no qual elas podem ser resolvidas através da interação e do diálogo entre todos os envolvidos no problema".

No entanto, apontam alguns problemas que impedem a sociedade civil de exercer maior impacto sobre os direitos humanos e lançam alguns desafios nesse sentido, objetivando obter mais impacto e atingir uma consequente otimização dos resultados, como, por exemplo, o de melhorar nossa capacidade de comunicação e educação, a saber: "Atualmente, tanto os sistemas de comunicação quanto os de educação não se focalizam na promoção de um discurso social ou na difusão de informações sobre direitos humanos. As organizações de direitos humanos precisam melhorar sua capacidade de fazer uso desses sistemas, pois eles existem para ampliar o alcance do diálogo social. Isso significa dar continuidade e aperfeiçoar as iniciativas educacionais que não apenas apresentem às pessoas a linguagem dos direitos humanos, mas também abram caminho para diálogos proativos com os governos, o setor privado e outros movimentos sociais". (VIEIRA; DUPREE, 2005, p. 153). 
Denota-se, no entanto, que os Relatórios da Plataforma DhESCA já se tornaram um grande marco na construção de políticas públicas de direitos humanos, apesar de se constatar que ainda resta muito para que essa prática se consolide. 


\section{REFERÊNCIAS}

AÇÃO EDUCATIVA. Acesso à justiça. Disponível em:

<http://www.acaoeducativa.org.br/portal/index.php?option=com_content\&task=view\&id= 66\&Itemid=197>. Acesso em: 13 set. 2010.

Educação ainda é encarada pelo sistema prisional como um privilégio aos

presos. Disponível em:

<http://www.acaoeducativa.org.br/portal/index.php?option=com_content\&task=view\&id= 1684\&Itemid=149>. Acesso em: 12 out. 2011a.

O Piso Salarial Nacional para os profissionais da educação pública, a garantia de padrões mínimos. Disponível em:

$<$ http://www.acaoeducativa.org.br/portal/index.php?option=com_content\&task=view\&id= 1576\&Itemid=2 >. Acesso em: 12 out. 2011b.

AMARAL JÚNIOR, Alberto do; JUBILUT, Liliana Lyra (Org.). O STF e o Direito Internacional dos Direitos Humanos. São Paulo: Quartier Latin, 2009.

; PERRONE-MOISÉS, Cláudia (Org.). O cinqüentenário da Declaração

Universal dos Direitos do Homem. São Paulo: Edusp, 1999.

APPLE, Michael W. Educação e poder. Tradução Maria Cristina Monteiro. Porto Alegre: Artes Médicas, 1989.

ARGENTINA apresenta relatório sobre direitos humanos. Correio do Brasil, ano 12, n. 4.389, 3 dez. 2003. Disponível em: <http://correiodobrasil.com.br/argentina-aposentarelatorio-sobre-direitos-humanos/37477/>. Acesso em: 9 out. 2011.

ASSOCIAÇÃO DE COMBATE AOS POLUENTES. Relatores nacionais apresentam resultado à ONU: resumo executivo. Disponível em:

<http://www.acpo.org.br/biblioteca/09_leis_direito/direitos\%20humanos/DhESC.pdf>. Acesso em: 30 out. 2011.

BEISIEGEL, Celso de Rui. A qualidade do ensino na escola pública. Brasília: Líber Livro, 2005.

Educação e sociedade no Brasil após 1930. In: FAUSTO, Boris (Org.). História geral da civilização brasileira. III - O Brasil Republicano. São Paulo: Difel, 1986. p. 381-416.

BITTAR, Eduardo C. B. Violência e direitos humanos: o pensamento crítico-freudiano e o Estado de Direito, na berlinda entre civilização e barbárie. Revista Mestrado em Direito, Osasco, ano 7, n. 2, p. 197-226, 2007. 
; ALMEIDA, Guilherme Assis de (Org.). Minicódigo de direitos humanos. Brasília: Teixeira Gráfica e Editora, 2010.

BRASIL. Constituição da República Federativa do Brasil de 1988. Disponível em: <http://www.planalto.gov.br/ccivil_03/constituicao/constitui\%C3\%A7ao.htm>. Acesso em: 13 set. 2010a.

. Ministério da Educação. Conferência Nacional da Educação Básica.

Documento Final. Brasília, DF, 2008.

Plano Nacional de Segurança Pública (2000). Brasília, DF, 2000. Disponível em: <http://www.dhnet.org.br/3exec/novapolicia/plano_segpub.htm>. Acesso em: 21 nov. 2011.

Plataforma Brasileira de Direitos Humanos Econômicos, Sociais, Culturais e Ambientais. Disponível em:

$<$ http://www.dhescbrasil.org.br/index.php?option=com_docman\&Itemid=125>. Acesso em: 12 out. $2010 b$.

Presidência da República. Secretaria de Direitos Humanos. Direitos humanos: percepções da opinião pública: análises de pesquisa nacional. Organização: Gustavo Venturi. Brasília, DF, 2010c.

Presidência da República. Secretaria de Direitos Humanos Plano Nacional de Direitos Humanos III: formalizado em Decreto n. ${ }^{\circ}$ 7.037, de 21 de dezembro de 2009, atualizado pelo Decreto n. ${ }^{\circ} 7.177$, de 12 de maio de 2010. Disponível em:

<http://portal.mj.gov.br/sedh/pndh3/pndh3.pdf>. Acesso em: 13 set. 2010d.

CENTRAL INTELLIGENCE AGENCY. The World Factbook. Disponível em: <http://www.cia.gov/library/publications/the-world-factbook/geos/uy.html>. Acesso em: 20 nov. 2011.

COMPARATO, Fábio Konder. A afirmação histórica dos direitos humanos. 5. ed. rev. e atual. São Paulo: Saraiva, 2007.

CURY, Carlos Roberto Jamil. Ensino religioso na escola pública: o retorno de uma polêmica recorrente. Disponível em: 〈http://www.scielo.br/pdf/rbedu/n27/n27a12.pdf>. Acesso em: 21 ago. 2011.

; HORTA, José Silvério Baía; FÁVERO, Osmar. A Relação Educação-SociedadeEstado Pela Mediação Jurídico-Constitucional. In: FÁVERO, Osmar (Org.). A Educação nas Constituintes Brasileiras: 1823-1988. Campinas: Autores Associados, 1996. p. 5-30.

DEFENSORES do direito à educação investigam o Complexo do Alemão. Folha online, 8 out. 2007. Disponível em:

<http://www1.folha.uol.com.br/folha/educacao/ult305u334721.shtml>. Acesso em: 12 out. 2010 .

DIREITOS Humanos na Internet (DHnet). Disponível em: 〈http://www.dhnet.org.br/>. Acesso em: 3 mar. 2011. 
DUBET, François. A escola e a exclusão. Tradução Neide Luzia de Rezende. Cadernos de Pesquisa, São Paulo, n. 119, p. 29-45, jul. 2003.

DUBET, François. Quando o sociólogo quer saber o que é ser professor. Entrevista concedida a Angelina Teixeira Peralva e Marília Pontes Sposito. Tradução Ines Rosa Bueno. Revista Brasileira de Educação, São Paulo, n.5-6, p. 222-231, 1997.

DURKHEIM, Émile. Educação e Sociologia. São Paulo: Melhoramentos, 1972.

ENDO, Paulo Cesar: A violência no coração da cidade: um estudo psicanalítico sobre as violências na cidade de São Paulo. São Paulo: Escuta/Fapesp, 2005.

ESTIGARA, Adriana. O dever de adotar políticas públicas em decorrência da atuação do sistema interamericano de direitos humanos: uma análise a partir dos casos "Maria da Penha" e "Damião Ximenes". In: PIOVESAN, Flávia; IKAWA, Daniela (Coord.).

Direitos Humanos: fundamento, proteção e implementação. Curitiba: Juruá, 2007. p. 441474.

FARIA, José Eduardo. O Judiciário e os direitos humanos e sociais: notas para uma avaliação da justiça brasileira. In: (Org.). Direitos humanos, direitos sociais e justiça. São Paulo: Malheiros, 1998. p. 94-112.

FÁVERO, Osmar (Org.). A educação nas constituintes brasileiras: 1823-1988. Campinas: Autores Associados, 1996.

FEFERBAUM, Marina. Proteção internacional dos direitos humanos: análise do sistema africano. São Paulo: Saraiva, 2012.

FOODFIRST Information \& Action Network: Rede de Ação e Informação pelo Direito a se Alimentar (FIAN - Brasil). Disponível em: <http://www.fianbrasil.org.br/>. Acesso em: 30 out. 2011.

FUNDO das Nações Unidas para a Infância - Unicef. Disponível em:

<http://www.unicef.org.br/>. Acesso em: 30 out. 2011.

GHIRALDELLI JÚNIOR, Paulo. História da Educação Brasileira. 2. ed. São Paulo: Cortez, 2006.

GRACIANO, Mariângela. A educação como direito humano: a escola na prisão. 2005. 165 f. Dissertação (Mestrado em Educação) - Faculdade de Educação, Universidade de São Paulo, São Paulo, 2005.

HADDAD, Sérgio; GRACIANO, Mariângela (Org.). A educação entre os direitos humanos. São Paulo: Autores Associados/Ação Educativa, 2006.

INFANTI, Roberto. Alteração na LEP permite que pena de detentos seja reduzida por frequentarem a escola. Disponível em: <http://robertoinfanti.com.br/?p=1361>. Acesso em: 4 set. 2011. 
INTER-AGENCY Network for Education in Emergencies. Disponível em: <http://www.ineesite.org/index.php/post/o_que_e_a_inee>. Acesso em: 21 ago. 2011.

ISHAY, Micheline R. (Org.). Direitos Humanos: Uma Antologia - Principais Escritos Políticos, Ensaios, Discursos e Documentos desde a Bíblia até o Presente. Tradução Fábio Duarte Joly. São Paulo: Edusp/Núcleo de Estudos da Violência, 2006.

LIMA JÚNIOR, Jayme Benvenuto. Os direitos humanos econômicos, sociais e culturais. Rio de Janeiro: Renovar, 2001.

MANSO, Bruno Paes. STJ decide pela $1^{\text {a }}$ vez federalizar um crime por violação a direitos humanos. O Estado de S. Paulo. Clipping Eletrônico da Associação dos Advogados de São Paulo, 28 de outubro de 2010. Disponível em:

<http://www.aasp.org.br/aasp/imprensa/clipping/cli_noticia.asp?idnot=8704>. Acesso em: 3 nov. 2010.

MELLO, Cleyson de Moraes; FRAGA, Thelma Araújo Esteves. Direitos Humanos: coletânea de legislação. Rio de Janeiro: Freitas Bastos, 2003.

\section{NÚCLEO DE ESTUDOS DA VIOLÊNCIA. Relatório Nacional sobre os Direitos}

Humanos no Brasil: $3^{\circ}$. São Paulo: NEV, 2005. Disponível em:

<http://www.nevusp.org/downloads, 2002-2005>. Acesso em: 17 nov. 2011.

O BRASIL e os Direitos Humanos. O Estado de S. Paulo, São Paulo, 17 ago. 2009. Caderno Notas \& Informações, p. A3.

OBSERVATÓRIO DA EDUCAÇÃO. Conheça o trabalho das relatorias da Plataforma DhESCA/Brasil. 2009. Disponível em:

$<$ http://www.observatoriodaeducacao.org.br/index.php?view=article\&id=643\%3Aeducaca o-ainda-e-encarada-pelo-sistema-prisional-como-um-privilegio-aos-

presos\&option=com_content\&Itemid=107>. Acesso em: 5 abr. 2011.

OLIVEIRA, Romualdo Portela de. Educação e cidadania: o direito à educação na Constituição de 1988 da República Federativa do Brasil. 1995. 179 f. Tese (Doutorado em Educação) - Faculdade de Educação, Universidade de São Paulo, São Paulo, 1995.

OLIVEIRA, Rosimar de Fátima. O papel do Poder Legislativo na formulação das políticas educacionais. 2005. 262 f. Tese (Doutorado em Educação) - Faculdade de Educação, Universidade de São Paulo, São Paulo, 2005.

OPERA MUNDI. Relatório da Cruz Vermelha denuncia violações de direitos humanos na Colômbia. 14 abr. 2011. Disponível em: <http://operamundi.uol.com.br/conteudo/noticia/RELATORIO+DA+CRUZ+VERMELHA +DENUNCIA+VIOLACOES+DE+DIREITOS+HUMANOS+NA+COLOMBIA_11253.s html>. Acesso em: 9 out. 2011. 
Unidas, de 4 de dezembro de 1986. Disponível em:

<http://www.dhnet.org.br/direitos/sip/onu/spovos/lex170a.htm>. Acesso em: 28 nov. 2011.

ORGANIZAÇÃO DAS NAÇÕES UNIDAS. Declaração Universal dos Direitos Humanos. Disponível em:

<http://portal.mj.gov.br/sedh/ct/legis_intern/ddh_bib_inter_universal.htm>. Acesso em: 17 maio 2010.

. Programa das Nações Unidas para o Desenvolvimento: Pnud Brasil.

Disponível em: <http://www.pnud.org.br/unv/>. Acesso em: 9 out. 2011.

ORGANIZAÇÃO DOS ESTADOS AMERICANOS. Convenção Americana de Direitos Humanos. San José da Costa Rica, 1969. Disponível em:

<http://www.pge.sp.gov.br/centrodeestudos/bibliotecavirtual/instrumentos/sanjose.htm>. Acesso em: 13.09.2010.

PATTO, Maria Helena Souza. "Escolas cheias, cadeias vazias": nota sobre as raízes ideológicas do pensamento educacional brasileiro. Estudos Avançados, São Paulo, v. 21, n. 61, p. 243-266, set./dez. 2007.

PEREIRA, Luiz; FORACCHI, Marialice M. Educação e Sociedade: Leituras de sociologia da educação. 9. ed. São Paulo: Companhia Editora Nacional, 1978.

PINHEIRO, Maria Francisca. O Público e o Privado na Educação: um conflito fora de moda? In: FÁVERO, Osmar (Org.). A Educação nas Constituintes Brasileiras: 18231988. Campinas: Autores Associados, 1996. p. 255-291.

PIOVESAN, Flávia. Direitos Humanos e o Direito Constitucional Internacional. 10. ed. rev. e atual. São Paulo: Saraiva, 2009.

Saraiva, 2010.

Direitos Humanos e o Direito Constitucional Internacional. São Paulo:

Proteção Internacional dos Direitos Econômicos, Sociais e Culturais. In:

SARLET, Ingo Wolfgang (Org.). Direitos fundamentais sociais: estudos de direito constitucional, internacional e comparado. Rio de Janeiro: Renovar, 2003. p. 233-261.

PLATAFORMA Brasileira de Direitos Humanos Econômicos, Sociais, Culturais e Ambientais. Disponível em:

$<$ http://www.dhescbrasil.org.br/index.php?option=com_content $\&$ view=category\&layout=b log\&id=148\&Itemid=136>. Acesso em: 9 out. 2011.

PLATAFORMA BRASILEIRA DE DIREITOS HUMANOS ECONÔMICOS, SOCIAIS, CULTURAIS E AMBIENTAIS. Desafios dos Direitos Humanos no Brasil e a experiência das Relatorias Nacionais em DhESCA: Informe 2007/2009. Curitiba, 2009a. Disponível em:

<http://issuu.com/plataformadhesc/docs/desafios_direitos_humanos\#download>. Acesso em: 14 ago. 2011. 
Informe 22: Boletim Informativo da Plataforma Dhesca Brasil, out. $2009 \mathrm{~b}$.

Disponível em:

<http://www.pidhdd.org/index.php?option=com_content\&task=view\&id=1311\&Itemid=9 9>. Acesso em: 12 out. 2011.

PLATAFORMA BRASILEIRA DE DIREITOS HUMANOS ECONÔMICOS, SOCIAIS, CULTURAIS E AMBIENTAIS. Nove meses depois - O que mudou? Informe de Seguimento sobre o Relatório referente à violação dos direitos educativos no Complexo do Alemão (RJ). 2008. Disponível em:

<http://www.dhescbrasil.org.br/attachments/151_Complexo\%20do\%20Alemão\%20.\%20R J.pdf >. Acesso em 30 abr. 2011.

PRADO JÚNIOR, Bento. Alguns ensaios: filosofia, literatura, psicanálise. São Paulo: Max Limonad, 1985.

RAMOS, André de Carvalho. Teoria geral dos direitos humanos na ordem internacional. Rio de Janeiro: Renovar, 2005.

. Direitos humanos em juízo - comentários aos casos contenciosos e consultivos da Corte Interamericana de Direitos Humanos. São Paulo: Max Limonad, 2001.

RELATORIA NACIONAL PARA O DIREITO HUMANO À EDUCAÇÃO. Plataforma Dhesca Brasil. Educação nas prisões do Brasil. 2009. Disponível em: http://www.dhescbrasil.org.br/attachments/289_Educação\%20nas\%20prisões\%20do\%20B rasil.pdf. Acesso em: 14 ago. 2011.

. Plataforma Dhesca Brasil. Violação dos direitos educativos da comunidade do Complexo do Alemão (Rio de Janeiro). 2007. Disponível em: <http://www.dhescbrasil.org.br/attachments/151_Complexo\%20do\%20Alemão\%20.\%20R J.pdf>. Acesso em: 30 abr. 2011.

RELATORIAS DE DIREITOS HUMANOS. Informe 2009/2011. Brasília, DF: DhESCA Brasil, 2011. Disponível em:

<http://issuu.com/plataformadhesc/docs/relatoriasdedireitoshumanos>. Acesso em: 12 out. 2011 .

RELATORIAS NACIONAIS EM DIREITOS HUMANOS ECONÔMICOS, SOCIAIS E CULTURAIS. Informe 2004. Disponível em:

<http://www.rolim.com.br/2002/_pdfs/0621.pdf>. Acesso em: 17 nov. 2011.

RELATÓRIO Brasileiro sobre Direitos Humanos Econômicos, Sociais e culturais - meio ambiente, saúde, moradia adequada e à terra urbana, educação, trabalho, alimentação, água e terra rural. Projeto Relatores Nacionais em Direitos Humanos Econômicos, Sociais e Culturais. Recife: Bagaço, 2003.

REQUISITOS mínimos para a educação em situação de emergência, crises crónicas e reconstrução. Viana do Castelo: Escola Superior de Educação, Instituto Politécnico de Viana do Castelo, 2006. Disponível em: 
<http://www.ineesite.org/minimum_standards/INEE_MSEE_PT.pdf >. Acesso em: 21 ago. 2011.

ROCHA, Marlos Bessa Mendes da. Tradição e Modernidade na Educação: O Processo Constituinte de 1933-34. In: FÁVERO, Osmar (Org.). A educação nas constituintes brasileiras: 1823-1988. Campinas: Autores Associados, 1996. p. 119-138.

ROY, Pierre Toussaint (Org.). Campaña Latinoamericana por el derecho a la educación: por una agenda educativa latinoamericana. Memoria del III encuentro latinoamericano de la sociedad civil para la incidencia en políticas educativas. Tradução Paula Rodrigues. Porto Alegre, 2005. Disponível em:

<http://www.campanaeducacion.org>. Acesso em: 13 set. 2010.

SARLET, Ingo Wolfgang. A eficácia dos direitos fundamentais. Porto Alegre: Livraria do Advogado, 2006.

(Org.). Direitos fundamentais sociais: estudos de direito constitucional,

internacional e comparado. Rio de Janeiro: Renovar, 2003.

SÃO PAULO (Estado). Programa Estadual de Direitos Humanos de São Paulo. São Paulo, Decreto n. ${ }^{\circ}$ 42.209, de 15 de setembro de 1997. Disponível em:

<http://www.justica.sp.gov.br/Modulo.asp?Modulo=480\&Cod=2>. Acesso em: 13 set. 2010 .

SÃO PAULO (Município). Prefeitura Municipal. Plano de Direitos Humanos da Cidade de São Paulo. São Paulo, 1998. Disponível em:

<http://www.dhnet.org.br/dados/pp/pmdh/sp/pdhsp.htm>. Acesso em: 13 set. 2010.

Secretaria Municipal de Educação. Plano de Educação da Cidade de São Paulo.

São Paulo, 2009. Disponível em:

<http://www.sinpeem.com.br/sites/arquivos/downloads/construcaodopme.pdf >. Acesso em: 13 set. 2010 .

SCHILLING, Flávia Inês. O direito à educação: um longo caminho. In: BITTAR, Eduardo C. B. (Coord.). Educação e Metodologia para os direitos humanos. São Paulo: Quartier Latin, 2008. p. 273-284.

SILVA, José Afonso da. Curso de Direito Constitucional Positivo. 28. ed. rev. e atual. São Paulo: Malheiros, 2007.

SILVEIRA, Rosa Maria Godoy; DIAS, Adelaide Alves; FERREIRA, Lúcia de Fátima Guerra; FEITOSA, Maria Luíza Pereira de Alencar Mayer; ZENAIDE, Maria de Nazaré Tavares (Org.). Educação em direitos humanos: fundamentos teórico-metodológicos. João Pessoa: Editora Universitária, 2007.

SIMIELLI, Lara Elena Ramos. A luta pela melhoria da educação pública no Brasil: as coalizões contemporâneas e os movimentos sociais históricos. Processo eletrônico: 2010/00514-6 (cópia impressa do livro). 
SPOSITO, Marília Pontes. O povo vai à escola: a luta pela expansão do ensino público em São Paulo. São Paulo: Loyola, 1984.

TERRA DE DIREITOS. Organização de Direitos Humanos. Plataforma Dhesc nomeia novos relatores, Curitiba, 16 maio 2005. Disponível em:

$<$ http://terradedireitos.org.br/biblioteca/notícias/plataforma-dhesc-nomeia-novosrelatores/>. Acesso em: 12 abr. 2011.

TOMASEVSKI, Katarina. El asalto a la educación. Tradução do Departamento de Publicações da Faculdade de Direito da Universidade de Buenos Aires e Katarina Tomasevski. Barcelona: Intermón Oxfam, 2004.

TORRES, Ricardo Lobo. A metamorfose dos direitos sociais em mínimo existencial. In: SARLET, Ingo Wolfgang (Org.). Direitos Fundamentais Sociais: Estudos de Direito Constitucional, Internacional e Comparado. Rio de Janeiro: Renovar, 2003. p. 1-46.

TRAGTENBERG, Maurício. Sobre educação, política e sindicalismo. São Paulo: Cortez, 1982.

UNITED Nations Volunteers - UNV. Disponível em: <http://www.unv.org/>. Acesso em: 30 out. 2011.

UNIVERSIDADE LIVRE FEMINISTA. Argentina: Relatório destaca violações aos Direitos Humanos de população LGBT. 18 ago. 2010. Disponível em: <http://www.feminismo.org.br/livre/index.php?option=com_content\&view=article \&id=20 27:argentina-relatorio-destaca-violacoes-aos-direitos-humanos-de-populacaolgbt\&catid=73:music \&Itemid=417>. Acesso em: 09 out. 2011.

URUGUAY. Ministerio de Educación y Cultura. Lei General de Educación de la Republica del Uruguai. Ley n. ${ }^{\circ}$ 18.437/08. Disponível em:

<http://www.leyeducacion.mec.gub.uy/doc/texto_completo_ley_educacion.pdf >. Acesso em: 15 set. 2010 .

Ministerio de Educación y Cultura. Dirección de Educacion. Área de Investigación y Estadística. Anuário 2009. Disponível em: $<$ http://educacion.mec.gub.uy/boletin/En\%20Web/Parte\%20I\%20Cap\%C3\%ADtulo\%201. 1.pdf $>$. Acesso em: 20 nov. 2011.

VEÇOSO, Fábia Fernandes Carvalho. O Poder Judiciário e os Direitos Humanos: um panorama sobre a discussão relativa à justiciabilidade desses direitos. In: AMARAL JUNIOR, Alberto do; JUBILUT, Liliana Lyra (Org.). O STF e o Direito Internacional dos Direitos Humanos. São Paulo: Quartier Latin, 2009. p. 79-98.

VEIGA, Cynthia Greive. História da Educação. São Paulo: Ática, 2007.

VIEIRA, Oscar Vilhena (Org.). Direitos Humanos: Normativa Internacional. São Paulo: Max Limonad, 2001.

; DUPREE, Andrew Scott. Sociedade civil e direitos humanos. In:

(Coord.). Direitos humanos: Estado de Direito e a construção da paz. São Paulo: Quartier Latin, 2005. p. 141-155. 


\section{APÊNDICE A - Informações gerais do relatório brasileiro sobre os DhESC/2003}

\begin{tabular}{|c|c|c|c|}
\hline Relatório & Responsáveis & Participantes & Temas centrais \\
\hline $\begin{array}{l}\text { Relatório } \\
\text { Brasileiro } \\
\text { sobre Direitos } \\
\text { Humanos } \\
\text { Econômicos, } \\
\text { Sociais e } \\
\text { Culturais - } \\
\text { DhESC/2003 }\end{array}$ & $\begin{array}{l}\text { Coordenador do } \\
\text { projeto e } \\
\text { organizador do } \\
\text { relatório: Jayme } \\
\text { Benvenuto Lima Jr. } \\
\text { Relatores nacionais } \\
\text { em DhESC*: } \\
\text { Flavio Luiz Schieck } \\
\text { Valente; Jean- } \\
\text { Pierre Leroy; } \\
\text { Eleonora Menicucci } \\
\text { de Oliveira; Nelson } \\
\text { Saule Jr.; Sérgio } \\
\text { Haddad; Lucila } \\
\text { Bandeira Beato. } \\
\text { Assessores } \\
\text { Nacionais em } \\
\text { DhESC: Valéria } \\
\text { Torres Amaral } \\
\text { Burity; Daniel } \\
\text { Ribeiro Silvestre; } \\
\text { Lúcia Maria Xavier } \\
\text { de Castro; Letícia } \\
\text { Marques Osório; } \\
\text { Mariângela } \\
\text { Graciano; Cléber } \\
\text { Vicente Gonçalves } \\
\text { Silva. }\end{array}$ & $\begin{array}{l}\text { 1) Organizações da sociedade } \\
\text { civil: Federação de Órgãos para } \\
\text { a Assistência Social e } \\
\text { Educacional (Fase); Movimento } \\
\text { Nacional de Direitos Humanos } \\
\text { (MNDH); Gabinete de } \\
\text { Assessoria Jurídica às } \\
\text { Organizações Populares (Gajop); } \\
\text { Centro de Justiça Global; } \\
\text { FoodFirst Information \& Action } \\
\text { Network - Rede de Ação e } \\
\text { Informação pelo Direito a se } \\
\text { Alimentar (Fian - Brasil) e } \\
\text { Comissão de Justiça e Paz de } \\
\text { São Paulo. } \\
\text { 2) Organismos do Estado } \\
\text { brasileiro: } \\
\text { Comissão de Direitos Humanos } \\
\text { da Câmara Federal; } \\
\text { Departamento de Direitos } \\
\text { Humanos do Ministério das } \\
\text { Relações Exteriores; } \\
\text { Procuradoria Federal dos } \\
\text { Direitos do Cidadão e Secretaria } \\
\text { Especial de Direitos Humanos. } \\
\text { 3) Entidades ligadas às Nações } \\
\text { Unidas: Fundo das Nações } \\
\text { Unidas para a Infância (Unicef); } \\
\text { United Nations Volunteers } \\
\text { (UNV) e Programa das Nações } \\
\text { Unidas para o Desenvolvimento } \\
\text { (Pnud). }\end{array}$ & $\begin{array}{l}\text { Direito } \\
\text { humano ao } \\
\text { Meio } \\
\text { Ambiente; } \\
\text { Direito } \\
\text { Humano à } \\
\text { Saúde; } \\
\text { Direitos } \\
\text { Humanos à } \\
\text { Moradia } \\
\text { Adequada e à } \\
\text { Terra Urbana; } \\
\text { Direito } \\
\text { Humano à } \\
\text { Educação; } \\
\text { Direito } \\
\text { Humano ao } \\
\text { Trabalho; } \\
\text { Direitos } \\
\text { Humanos à } \\
\text { Alimentação, } \\
\text { Água e Terra } \\
\text { Rural. }\end{array}$ \\
\hline
\end{tabular}

* grupo de relatores nomeados em 2002 pelo Conselho de Escolha dos Relatores Nacionais em Direitos Humanos Econômicos, Sociais e Culturais. 


\section{APÊNDICE B - Principais informações sobre a educação contidas no relatório brasileiro sobre os DhESC/2003}

\begin{tabular}{|c|c|c|c|}
\hline Relator/Assessora & $\begin{array}{l}\text { Local escolhido } \\
\text { para a observação }\end{array}$ & $\begin{array}{l}\text { Duração da } \\
\text { missão }\end{array}$ & $\begin{array}{l}\text { Principais aspectos } \\
\text { abordados }\end{array}$ \\
\hline $\begin{array}{l}\text { Sérgio Haddad/ } \\
\text { Mariângela } \\
\text { Graciano }\end{array}$ & Fortaleza/CE & $\begin{array}{l}18 \text { a } 21 \text { de } \\
\text { fevereiro de } \\
2003\end{array}$ & $\begin{array}{l}\text { Avaliação da educação } \\
\text { no Brasil sob o ponto de } \\
\text { vista dos direitos } \\
\text { humanos; análise do } \\
\text { contexto educacional } \\
\text { dos últimos anos; } \\
\text { resultados da missão da } \\
\text { Relatoria em Fortaleza, a } \\
\text { partir das denúncias } \\
\text { recebidas sobre } \\
\text { problemas relativos ao } \\
\text { acesso e outros } \\
\text { relacionados à } \\
\text { qualidade. }\end{array}$ \\
\hline
\end{tabular}




\section{APÊNDICE C - Principais informações sobre a educação}

contidas no informe sobre os DhESC/2004

\begin{tabular}{|l|l|l|l|}
\hline Relator/Assessora & $\begin{array}{l}\text { Local escolhido } \\
\text { para a } \\
\text { observação }\end{array}$ & $\begin{array}{l}\text { Duração da } \\
\text { missão }\end{array}$ & $\begin{array}{l}\text { Principais aspectos } \\
\text { abordados }\end{array}$ \\
\hline $\begin{array}{l}\text { Sérgio Haddad/ } \\
\text { Mariângela }\end{array}$ & $\begin{array}{l}\text { Alagoas e } \\
\text { Amazonas }\end{array}$ & $\begin{array}{l}\text { Janeiro de 2003 a } \\
\text { setembro de 2004 }\end{array}$ & $\begin{array}{l}\text { Relatos sobre } \\
\text { violações ao direito à } \\
\text { educação constatadas } \\
\text { durante as missões } \\
\text { realizadas nos Estados } \\
\text { de Alagoas e } \\
\text { Amazonas; entraves à } \\
\text { efetivação de modo } \\
\text { universal do direito à } \\
\text { educação: desvios na } \\
\text { utilização de recursos } \\
\text { públicos destinados à } \\
\text { educação e desrespeito } \\
\text { às diversidades } \\
\text { culturais e demais } \\
\text { peculiaridades cujo } \\
\text { reconhecimento é } \\
\text { necessário à } \\
\text { implementação da } \\
\text { educação indígena. }\end{array}$ \\
\hline
\end{tabular}




\section{APÊNDICE D - Principais informações contidas no relatório de 2007 sobre a violação dos direitos educativos da Comunidade do Complexo do}

Alemão

\begin{tabular}{|l|l|l|l|}
\hline Relatora/Assessora & $\begin{array}{l}\text { Local escolhido } \\
\text { para a } \\
\text { observação }\end{array}$ & $\begin{array}{l}\text { Duração da } \\
\text { missão }\end{array}$ & $\begin{array}{l}\text { Principais aspectos } \\
\text { abordados }\end{array}$ \\
\hline $\begin{array}{l}\text { Denise Carreira/ } \\
\text { Suelaine Carneiro }\end{array}$ & $\begin{array}{l}\text { Rio de Janeiro/RJ } \\
- \text { Conjunto de } \\
\text { favelas localizado } \\
\text { na zona norte da } \\
\text { cidade do Rio de } \\
\text { Janeiro (Morro do } \\
\text { Alemão) }\end{array}$ & $\begin{array}{l}8 \text { de } 2007 \\
\text { Relação direta entre } \\
\text { educação e } \\
\text { segurança pública: } \\
\text { apuração da violação } \\
\text { dos direitos } \\
\text { educativos de } \\
\text { crianças, jovens e } \\
\text { adultos que } \\
\text { frequentam as } \\
\text { escolas públicas do } \\
\text { Complexo do } \\
\text { Alemão, devido aos } \\
\text { frequentes embates } \\
\text { entre a força policial } \\
\text { e o narcotráfico, } \\
\text { afetando diretamente } \\
\text { o serviço } \\
\text { educacional daquela } \\
\text { região. }\end{array}$ \\
& & &
\end{tabular}




\section{APÊNDICE E - Principais informações contidas no relatório sobre a educação nas prisões brasileiras}

\begin{tabular}{|c|c|c|c|}
\hline Relatora/Assessora & $\begin{array}{l}\text { Local escolhido } \\
\text { para a observação }\end{array}$ & $\begin{array}{l}\text { Duração da } \\
\text { missão }\end{array}$ & $\begin{array}{l}\text { Principais aspectos } \\
\text { abordados }\end{array}$ \\
\hline $\begin{array}{l}\text { Denise Carreira/ } \\
\text { Suelaine Carneiro }\end{array}$ & $\begin{array}{l}\text { Pernambuco; Pará; } \\
\text { Rio Grande do Sul; } \\
\text { São Paulo e Distrito } \\
\text { Federal }\end{array}$ & $\begin{array}{l}\text { outubro de } 2008 \text { a } \\
\text { abril de } 2009\end{array}$ & $\begin{array}{l}\text { A educação nas } \\
\text { prisões vista como } \\
\text { um favor ou mera } \\
\text { concessão aos } \\
\text { detentos; as } \\
\text { violações de direitos } \\
\text { humanos em geral } \\
\text { assistidas no sistema } \\
\text { prisional; a } \\
\text { descontinuidade do } \\
\text { atendimento } \\
\text { educacional nas } \\
\text { unidades. }\end{array}$ \\
\hline
\end{tabular}

